\title{
New Perspectives on Telemann's Instrumental Music at the Dresden Electoral Court
}

One of the most important subrepertories in the Dresden electoral Hofkapelle's extensive music collection, filed for decades in "Schranck No: II" of the Catholic court church, is a group of 171 manuscripts transmitting at least 149 different instrumental works by Georg Philipp Telemann. Its significance has long been recognized, for among extant eighteenth-century collections of the composer's sonatas, concertos, and suites, only that of the Darmstadt Hofkapelle is larger. During the 1980s and 1990s, the Dresden Telemann manuscripts were the subject of several source-critical studies by Ortrun Landmann, Manfred Fechner and myself focusing on copyists and paper types - investigations that deepened our understanding of how the composer's music was acquired and performed by Germany's most illustrious Hofkapelle. ${ }^{1}$ But this rich corpus has not been examined in its entirety for some years now. The present essay's purpose, then, is to reassess the manuscripts in light of recent research into the wider "Schrank II" repertory by Landmann ${ }^{2}$ and scholars associated with the Deutsche Forschungsgemeinschaft project "Die Instrumentalmusik der Dresdner Hofkapelle zur Zeit der sächsisch-polnischen Union. Erschließung, Digitalisierung und Internetpräsentation" (2008-2011). After taking a holistic view of the Dresden Telemann collection (a perspective lacking since Landmann's landmark study of 1983), I shall consider the significance of several recently discovered sources and revisit the status of an anonymous scribe known in the literature as Dresden "Schreiber P".

An overview of the Dresden Telemann repertory is provided in Table 1, which arranges the manuscripts into four broad chronological groups (labelled A through D) based on our present

1 See, in particular, Ortrun Landmann, Die Telemann-Quellen der Sächsischen Landesbibliothek: Handschriften und zeitgenössische Druckausgaben seiner Werke, Dresden 1983 (Studien und Materialien zur Musikgeschichte Dresdens. 4); Manfred Fechner, Studien zur Dresdner Überlieferung von Instrumentalkonzerten Deutscher Komponisten des 18. Jahrhunderts, Laaber 1999 (Dresdner Studien zur Musikwissenschaft. 2); and Steven Zohn, "Music Paper at the Dresden Court and the Chronology of Telemann's Instrumental Music", in: Puzzles in Paper: Concepts in Historical Watermarks. Essays from the International Conference on the History, Function, and Study of Watermarks, Roanoke, Virginia, edited by Daniel W. Mosser, Michael Saffle and Ernest W. Sullivan II, New Castle, D.E., and London 2000, pp. 125-168.

2 Ortrun Landmann, Über das Musikerbe der Sächsischen Staatskapelle. Drei Studien zur Geschichte der Dresdner Hofkapelle und Hofoper anhand ihrer Quellenüberlieferung in der SLUB Dresden, ${ }^{2} 2010$, https://nbn-resolving.org/urn:nbn:de:bsz:14-qucosa-38515. 
knowledge of copyists' hands and paper types. ${ }^{3}$ It is important to realize that the boundaries between these groups are necessarily fluid, since dating a particular scribe's activity or tracing a given paper type's provenance is in many instances an approximate science.

The music of Group A is heavily weighted towards sonatas (TWV 41-44) and concertos (TWV 51-54), with an emphasis on trios and quartets for strings and concertos for one or two solo violins. This is precisely the type of instrumental music Telemann recalled having concentrated on during his years at the Eisenach court (1708-1712), and it would naturally have appealed to the composer's close friend, the Dresden violinist and eventual Konzertmeister Johann Georg Pisendel. ${ }^{4}$ In fact, most of the music in Group A may, with due caution, be assigned to the composer's Eisenach and Frankfurt periods (1708-1721) on the basis of stylistic criteria. Conspicuously modest in number are the overture-suites (TWV 55); on the whole, they appear to be slightly later works than the sonatas and concertos, probably originating from Telemann's Frankfurt and early Hamburg years (1712-1725). It would appear from the surviving sources that before 1728, the Hofkapelle under Jean-Baptiste Woulmyer preferred overture-suites drawn from the stage works of Campra, Lully and other Frenchmen to newly composed works by Germans, though in addition to suites by Telemann, this early repertory includes examples by Gottfried Finger, Johann Joseph Fux, Georg Friedrich Händel, Johann Christoph Pez and Johann Christoph Schmidt. ${ }^{5}$ None of the music from Telemann's Frankfurt publications is represented in Group A, but present are eight sonatas that later appeared in two unauthorized Parisian editions: the Six Sonates en trio and Quatrième livre de quatuors. Remarkably, thirty-two of the seventy-three works in Group A, or 44\%, have no known manuscript concordances at other locations. This could be a sign that much of the music was intended specifically for Pisendel and his Dresden colleagues. Be that as it may, the status of works in Groups B-D is very different in this respect.

3 Excluded from the table are manuscripts of seven anonymous quartet sonatas (Mus.2-Q-21,1-7) that have been provisionally attributed to Telemann. I consider these works of doubtful authenticity from a stylistic standpoint. Also not reflected in the table are ten movements appearing to belong to three previously unknown overture-suites and a violin sonata movement. These last works are discussed below. I am grateful to Wolfgang Eckhardt for sharing with me watermark information about several manuscripts prior to the completion of the Deutsche Forschungsgemeinschaft project.

4 See Telemann's reminiscences in "Lebens-Lauff mein Georg Philipp Telemanns; Entworffen In Franckfurth am Mayn d. 10.[-14.] Sept. A. 1718”, in: Johann Mattheson, Grosse General-Baß-Schule. Oder: Der exemplarischen Organisten-Probe Zweite verbesserte und vermehrte Auflage, Hamburg 1731, reprint Hildesheim 1968, S. 176; and Johann Mattheson, Grundlage einer Ehren-Pforte, Hamburg 1740, reprint Kassel 1969, S. 362.

5 For a listing of this repertory, see Steffen Voss, “Teilsammlungen und ihre Identifizierung”, in: Schranck No: II. Das erhaltene Instrumentalmusikrepertoire der Dresdner Hofkapelle aus den ersten beiden Dritteln des 18. Jahrhunderts, edited by Gerhard Poppe, assisted by Katrin Bemmann, Wolfgang Eckhardt, Sylvie Reinelt and Steffen Voss, Beeskow 2012, pp. 38-42 (Forum Mitteldeutsche Barockmusik. 2). In addition to single theatrical overtures, the French works include excerpts from ballets, operas, and opera-ballets by André Campra (Aréthuse, Les Muses, L' Europe galante, and Tancrède), Pascal Colasse (Thétis et Pelée), André Cardinal Destouches (Issé), Jean-Baptiste Lully (Achille et Polyxène, Acis et Galatée, Amadis, Armide, Atys, Cadmus et Hermione, Idylle sur la paix, Isis, Le temple de la paix, Les fêtes de l'Amour et de Bacchus, Le triomphe de l'Amour, Persée, Phaëton, Proserpine, Roland, and Thésée), Louis Lully (Orphée), Marin Marais (Alcyone), Jean Joseph Mouret (Les fêtes), and Jean Féry Rebel (La petite Drôt and Les caractères de la danse). The relevant shelfmarks are Mus.1827-F-2, ...F-6, ...F-8, ..F-11, ..F-13, ...F-15, ..F-17, ..F-21, ..F-30 ...F-37; Mus.1859-F-2a; Mus.2111-F-3; Mus.2124-F-2, ...F-5, ..F-6, ..F-9, ...F-10; Mus.2146-N-1-2; Mus.2148-F-2; Mus.2231-F-1; Mus.2394-N-3. 
A high percentage of the Group A manuscripts are in unidentified hands, though the presence of musicians who were members of the Hofkapelle such as Pisendel (responsible in whole or in part for thirty manuscripts, or $39 \%$ of the total), Johann Jacob Lindner and Johann Joachim Quantz is noteworthy. There is also a number of 'outside' sources. As Manfred Fechner has suggested, "Schreiber v's" four manuscripts ${ }^{6}$ may have originated at the Weimar court, as did Mus.2392-O-35a (TWV 52:G2), copied in part by J.S. Bach. ${ }^{7}$ Some or all of the five Telemann composing scores may also be considered outside sources. ${ }^{8}$ Five more manuscripts are in the hand of S-Dl-013, an unidentified central German copyist whom Steffen Voss links to Pisendel during the violinist's Leipzig period of 1709-1711. ${ }^{9}$ These manuscripts would have been brought to Dresden by Pisendel in $1712 .{ }^{10}$ Drawing on the research of Jóhannes Ágústsson, Michael Talbot notes that three manuscripts of Telemann trios, each entitled "Concerto à tre", ${ }^{11}$ were copied by Giovanni Battista Vivaldi (the composer's father) in Venice in 1716 / 17. The music was presumably written by Telemann for the Venice-based Kammermusik of Kurprinz Friedrich August, an ensemble consisting of Pisendel (or perhaps, in his absence, Antonio Vivaldi), the wind player Johann Christoph Richter and the keyboardist Christian Pezold. ${ }^{12}$ Finally, Wolfgang Eckhardt has identified S-Dl-001, the copyist of Mus.2392-Q-82 (TWV 43:g4) and principal copyist of Mus.2392-O-56 (TWV 52:e4), as Leipzig Anon. Vn, a scribe who wrote out three cantata flute parts for J. S. Bach in 1724/ 25 (BWV 94, 101, and 8). The presence in the Dresden manuscripts of paper with watermarks W-Dl-026/031 (Zohn 4; a crowned, oval-shaped Saxon electoral crest) and W-Dl-082 (Zohn 9) HB (the letters "HB" suspended below a crowned shield containing a posthorn) suggests that Anon. Vn was active at Dresden only until the early 1720 s. ${ }^{13}$

6 Mus.2392-O-17a (TWV 51:g1), ...O-35b (52:G2), ...Q-23 (42:d6), ...R-3 (41:fis2).

7 Fechner, Studien 1999 (as footnote 1), p. 136.

8 Mus.2392-O-9 (TWV 51:F4), ...O-18 (53:D1), ...O-22 (53:h1), ..O-34 (55:B11), ..O-38 (51:B1). - On the possibility that TWV 53:D1 and h1 were composed at Dresden during the composer's 1719 visit, see Zohn, Paper 2000 (as footnote 1), pp. 159 f.; and idem, Music for a Mixed Taste: Style, Genre, and Meaning in Telemann's Instrumental Works, New York 2008, p. 140. A sixth Telemann composing score, to the double concerto TWV 52:e2, formerly belonged to the Dresden Hofkapelle but is now at the Bibliothèque du Conservatoire National de Musique Paris (F-Pc: Ms. 2205). It also appears to have originated around 1719, and left Dresden some time during the second half of the nineteenth century. See Fechner, ibid., p. 222; and Zohn, ibid., p. 160.

9 Mus.2392-O-28 (TWV 44:41), ...O-47 (51:d1), ...Q-18 (42:a5), ..Q-21 (42:h7), ..R-2 (41:A7).

10 Voss, Teilsammlungen und ihre Identifizierung 2012 (as footnote 5), pp. 34-36. Here and below, copyist numbers beginning with "S-Dl” are those assigned by the research project "Die Instrumentalmusik der Dresdner Hofkapelle zur Zeit der sächsisch-polnischen Union”.

11 Mus.2392-Q-31 (TWV 42:D15), ...Q-37 (42:e7), ...Q-55 (42:A9).

12 See Michael Talbot, "Giovanni Battista Vivaldi Copies Music by Telemann: New Light on the Genesis of Antonio Vivaldi's Chamber Concertos”, in: Studi vivaldiani 15 (2015), pp. 55-72. All three manuscripts were formerly thought to be in the hand of Giovanni Alberto Ristori, who served as "Compositeur de la musique italienne" at the electoral court. See Landmann, Telemann 1983 (as footnote 1), p. 149.

13 Here and below, watermark numbers beginning with "W-Dl" are those assigned by the project "Die Instrumentalmusik der Dresdner Hofkapelle zur Zeit der sächsisch-polnischen Union”. Watermark numbers in parentheses derive from Zohn, Paper 2000 (as footnote 1), and are designated Zohn ... Letters, words or digits featured in the watermarks are added in italics. On the activities of S-Dl-001/Leipzig Anon. Vn, see Wolfgang Eckhardt, "Neue Erkenntnisse zu Bachs Kopist Anonymus Vn", in: Bach-Jahrbuch 2012, pp. 145-161. See also Eckhardt's discussion of this copyist in the multi-authored chapter "Über die Kopisten der im Schranck No: II aufbewahrten Manuskripte”, in: Schranck No: II 2012 (as footnote 5), p. $218 \mathrm{f}$. 
Some of the earliest sources in Group A are in fact those copied on paper with watermark W-Dl-082 (Zohn 9) $H B^{14}$ or variants of a watermark consisting of a crowned, oval-shaped Saxon electoral crest: watermarks W-Dl-026, 027, and 031 (Zohn 4). ${ }^{15}$ This group includes the E minor double violin concerto, TWV 52:e4, the Dresden copy of which can be dated to $1710 / 11$ based upon the performers' names written on the parts. ${ }^{16}$ In Lindner's copy of the ensemble concerto TWV 44:42, the two paper types appear together, as they do in orchestral part sets of suites extracted from André Campra's Aréthuse (Mus.2124-F-29) and Jean-Baptiste Lully's Achille et Polyxène (Mus.1827-F-32) and Armide (Mus.1827-F-34), copied in part by Lindner and Johann Wolfgang Schmidt. ${ }^{17}$ Significantly, paper containing these watermarks was not used by scribes known to have been active at the Dresden court from the late 1720 s onwards. ${ }^{18}$ Also appearing to date from the 1710s or early 1720 s are four manuscripts copied by Lindner on paper with watermark W-Dl-152 (Zohn 11), another crowned shield containing a posthorn, but with a fleur-de-lis countermark. ${ }^{19}$

Perhaps the most striking feature of Group B is that it provides almost a mirror Image of Group A: sonatas and concertos make up a smaller percentage of the whole, while overture-suites are much better represented than before. A large majority of Group B's sixty-seven manuscripts are in the early handwriting stages of the court copyist Johann Gottfried Grundig (Dresden "Schreiber A") and the violist Johann Gottlieb Morgenstern (Dresden "Schreiber D"), often with Pisendel supplying performance markings or doing some copying himself. Grundig and Morgenstern favoured paper with watermarks W-Dl-041 and 042 (Zohn 1; a double eagle with an acorn-shaped breast that may be the mark of the Michel mill in Dubí, Bohemia) and, perhaps slightly later, paper with watermark W-Dl-001 (Zohn 6) IGS (a posthorn in a crowned shield with the initials "I G S" suspended below for Johann Gottlob Schuchart, owner of a paper mill on the Weißeritz millstream in Dresden). Many of the copying hands of Group A are absent, and just a handful of manuscripts are wholly in the hand of Pisendel. Group B also contains most of the Telemann works used by the Dresden court as Kirchensinfonien: sonatas, concertos, and suites heard in orchestral doublings as Graduale instrumentaliter, and perhaps at other points during mass, in the Hofkirche between 1725 and the 1760 s. ${ }^{20}$ Often these works were performed as single movements, movement pairs, or as double movement pairs. A few of the manuscripts supplement

14 Mus.2392-N-6a (TWV 43:A6), ...N-9 (55:B9), ...O-3 (51:G8), ...O-4 (52:D3), ..O-11 (51:F2), ...O-56 (52:e4), ...Q-10 (43:A4), ...Q-76 (44:42), ...Q-82 (43:g4).

15 Mus.2392-O-56 (TWV 52:e4), ...Q-76 (44:42), ..Q-83 (43:a5), ..Q-84 (42:d11), ..Q-85a (42:D16).

16 Fechner, Studien 1999 (as footnote 1), pp. $237 \mathrm{f}$.

17 Similar Dresden suites compiled from stage works of Lully and copied by Lindner and J. W. Schmidt contain one or the other paper type: Amadis (Mus.1827-F-36; watermarks W-Dl-026 and 027 (Zohn 4)), Atys (Mus.1827-F-6; W-Dl-016, 030, 031 (Zohn 4), and 207 GWW)), and Les Fêtes de L'Amour et de Bacchus (Mus.1827-F-33; W-Dl082 (Zohn 9)).

18 A further indication of an early date for paper with watermarks showing a crowned, oval-shaped Saxon electoral crest is its presence in a set of parts to Telemann's cantata Herr, ich habe lieb die Stätte deines Hauses, TVWV 2:2, copied by Samuel Jacobi and Johann Siegmund Opitz, from the collection of the Fürstenschule in Grimma (Mus.2392-E-555). The title / wrapper for these parts bears several performance years, the earliest of which is 1715 .

19 Mus.2392-O-40 (TWV 55:h1), ...Q-3 (43:G5), ...Q-5 (42:G11), ...Q-15 (42:d9).

20 Mus.2392-N-1, ...N-5, ...N-6a and b, ..N-10, ..N-12, ..N-16 and 17, ..Q-3, ..Q-14a, ..Q-44b. 
older sets of single parts from Group A with freshly copied orchestral parts. Several more belong wholly to Group C. ${ }^{21}$

Although sixty-two of the seventy-three works in Group B are not transmitted in earlier Dresden sources, sixteen of these 'new' works were copied from Telemann's publications of the late 1720s and early 1730s (including Der getreue Music-Meister and the Essercizii musici, Quadri, Neue Sonatinen, III Trietti methodichi e III Scherzi and Musique de table); as in Group A, there are copies of sonatas that would later be published in the Six Sonates en trio and Quatrième livre de quatuors. Only fourteen works out of the total, or 19\%, have no known concordances outside Dresden - a far lower figure than the $44 \%$ of Group A. (Admittedly, this figure rises to 30\% if one uses as a total the forty-six works not previously copied at Dresden and not drawn from Telemann's publications.) This relatively low number of works unique to Dresden could indicate a change in Telemann's relationship to the Hofkapelle: perhaps he was no longer writing so many works specifically for its musicians. Or it could simply be that his music was now more widely disseminated than previously.

At first glance, it may seem surprising that the copying of Telemann's works at the Dresden court slowed considerably during the 1730s. After seventy-three works copied up to about 1725 (Group A), and another seventy-three produced during the following decade (Group B), just eighteen works can be assigned to the period after 1735 (Group C). (Too little is known about the five manuscripts of Group D to date them with any precision, though there are reasons to suspect that most originated during the first third of the eighteenth century.) This steep decline is likely a sign that Telemann was publishing most of his instrumental works during the 1730s and composed relatively few sonatas, concertos, and suites after $1740 .{ }^{22}$ Group C continues some of the patterns seen in Group B: manuscripts copied by Morgenstern, now in his latest handwriting stage, predominate along with those by the anonymous "Schreiber M"; concertos are outnumbered by overture-suites; and just a third of the works lack concordances elsewhere. On the other hand, a relatively high percentage of works (eight of eighteen) had already been copied at the court, including a complete set of the Six Sonates en trio (see Groups A and B). Half of the manuscripts in Group C contain paper with watermark W-Dl-002 (Zohn 7a) Dresden J G Schuchart (a large, crowned Saxon electoral crest in an elaborate cartouche above "Dresden J G Schuchart") or watermark W-Dl-007 (Zohn 7b) GHS (a similar crest, lacking the words but with a countermark of "GHS" - for Gabriel Heinrich Seydler - in a cartouche). Although paper with the former watermark came into use at the Dresden court only during the 1730s, examples of it may be found as early as the mid-1720s among the Grimma Telemann manuscripts. ${ }^{23}$ Paper with the latter watermark appears to have been in use at court around 1750. The exceptional source in Group C is Telemann's composing

21 Mus.2392-N-7, ...N-15, ...Q-50a and b. - For a discussion of this repertory, see Zohn, Music for a Mixed Taste 2008 (as footnote 8), pp. 186-189; and Voss, Teilsammlungen und ihre Identifizierung 2012 (as footnote 5), pp. 46-51.

22 A similar pattern occurs with the Telemann instrumental works preserved in Darmstadt manuscript copies, the vast majority of which were produced before 1740 .

23 For example, 1724 is the earliest performance date found on the title page to Mus.2392-E-597 (Es ist erschienen die heilsame Gnade Gottes, TVWV 1:507), copied by Egidius Börner. Dates of 1728 and 1729 are found, respectively, on the title pages to Mus.2392-E-560a (Ich bin der Erste und der Letzte, TVWV 1:816) and ...E-558a (Man singet mit Freuden vom Sieg, TVWV 1:1088), both copied by Opitz. 
score to the concerto TWV 51:F4 (Mus.2392-O-9), a work that was evidently written for Pisendel at Hamburg during the late 1740s or early 1750s, and which demonstrates Telemann's continuing relationship with the Dresden Hofkapelle. ${ }^{24}$

\section{New Sources in Context}

One fortunate result of the digitization project and other recent research on the Dresden Hofkapelle's repertory has been the identification of eleven new Telemann sources lurking among the many unattributed manuscripts in the "Schranck No: II" collection. ${ }^{25}$ These sets of parts include four Group A manuscripts containing two trio sonatas and a ripieno concerto, ${ }^{26}$ none of which are transmitted in other Dresden sources. The first three manuscripts are principally the handiwork of Pisendel, who copied on paper with watermark W-Dl-027 (Zohn 4); the fourth is in an unidentified hand (S-Dl-087) familiar from four other Dresden Telemann manuscripts. ${ }^{27}$

Pisendel's copy of TWV 43:a5 provides a third source for this ripieno concerto, which was previously known from a Darmstadt set of parts copied by Johann Samuel Endler during the 1720s or early 1730s (D-DS: Mus.ms.1042/47), and from an eighteenth-century score of Berlin provenance that came to light in the music archive of the Sing-Akademie zu Berlin in 2001 (D-Bsa: SA 3559 (5)). ${ }^{28}$ The Dresden parts likely predate these two concordant sources, and are alone in including continuo figures. Of greater import are Pisendel's copies of TWV 42:D16 and d11, which together with his parts to TWV 42:c4 (Mus.2392-Q-78) indicate that he may have owned a complete set of Telemann's so-called trios alla francese. ${ }^{29}$ Supporting the impression that these three works were copied within a short time span is their common scoring for two violins and continuo (most concordant sources specify flutes, oboes, or "dessus"), the presence of "tournez" directions for page turns in all three manuscripts, and Pisendel's collaboration with the same unidentified copyist in each bass part. ${ }^{30}$ In the case of Mus.2392-Q-85a, this second copyist's involvement ended almost

24 Zohn, Music for a Mixed Taste 2008 (as footnote 8), pp. 46-50.

25 Many of these identifications were first made by Wolfgang Eckhardt in connection with his dissertation research.

26 Mus.2392-Q-83 (TWV 43:a5), ...Q-84 (42:d11), ...Q-85a and b (42:D16).

27 Mus.2392-Q-1, ...Q-9, ...Q-13, ...Q-25.

28 Regarding D-Bsa: SA 3559, see Ralph-Jürgen Reipsch, “Der Telemann-Bestand des Notenarchivs der Sing-Akademie zu Berlin - ein Überblick”, in: Telemann der musikalische Maler - Telemann-Kompositionen im Notenarchiv der Sing-Akademie zu Berlin. Bericht über die Internationale Wissenschaftliche Konferenz Magdeburg, 10. bis 12. März 2004, anlässlich der 17. Magdeburger Telemann-Festtage, edited by Carsten Lange and Brit Reipsch, Hildesheim 2010, pp. 303 f. (Telemann-Konferenzberichte. 15).

29 On the sources and style of these six (or seven) works, see Steven Zohn, "New Light on Quantz's Advocacy of Telemann's Music", in: Early Music 25 (1997), pp. 441-461; and idem, Music for a Mixed Taste 2008 (as footnote 8), pp. 226-232. Although Brian D. Stewart suggested in an unpublished study of the Darmstadt Telemann sources that one of the two Darmstadt manuscripts transmitting TWV 42:c4 (D-DS: Mus. ms.1042/28a) is in the early hand of Pisendel (an identification I accepted in New Light, p. 446 f., and in Music for a Mixed Taste 2008 [as footnote 8], p. 227), close comparison with Pisendel's Dresden manuscripts reveals this attribution to be false.

30 The presence of this copyist was not recorded by researchers of the Deutsche Forschungsgemeinschaft project. Part titles in the three manuscripts are as follows: Mus.2392-Q-78, "Violon Premier", "Violon Secondo" and "Basso Continuo"; ...Q-84, "Violino Primo", "Violino 2. do", and "Basso"; and ...Q-85a, "Violino Primo", "Vio- 
as soon as it began: only the caption title "Basse", an erased designation of "Sonata", and the first bass clef (overwritten by Pisendel) are in his hand. However, in the bass part of Mus.2392-Q-78, Pisendel's collaborator copied the entire first movement, the caption title "Basso Continuo" and the first two bars of figures; the music and figures for the next three movements, all the movement titles, and a "tournez" indication, are Pisendel's work. Finally, all the music in the bass part of Mus.2392-Q-84, together with most first-movement figures, the caption title "Basso", the second-movement title "Menuet", and the indication "Tournez geschwindt" at the bottom of the first page, were supplied by our unknown scribe. As may be seen in Illustration 1, Pisendel wrote some figures for the first movement, all figures for the remaining three movements, and all movement titles, including "Sonata" at the beginning of the first movement and "En Menuet" to supersede the original "Menuet".

Pisendel's copy of TWV 42:d11 is the most important source for a work that until recently was considered lost. The anonymous Wiesentheid parts (D-WD: Ms. 875, identified in 1994) are missing a page of the bass part, lack continuo figures, and provide few agréments; the Berlin parts (D-Bsa: SA 3904, rediscovered in 2001) lack the third movement and are overloaded with agréments in the first, second, and fourth movements. ${ }^{31}$ Note in Illustration 2 that Pisendel's agréments for the first, third, and fourth movements are both tasteful and relatively restrained. Those for the third movement ("Lentement") are particularly instructive, as the Wiesentheid source gives no ornamentation at all. Although Pisendel's parts for TWV 42:D16 are less valuable for lacking bass figures after the opening bars of the first movement ("Gracieusement"), the agréments visible in Illustration 3 are fuller than those found in two Rostock concordances (D-ROu: Mus. saec. XVII. $18-45^{20}$ and $18-51^{56}$ ) and slightly less ornate than those of the Berlin source (D-Bsa: SA 3552, also rediscovered in 2001 and bearing the descriptive title Sonata a la francaise a 3). The copy of the trio by copyist S-Dl-087 (Mus.2392-Q-85b) was likely prepared from Pisendel's, though it is somewhat less accurate regarding slurs, trills, and dynamic indications, lacks the "tournez" indications, replaces "doux" with "piano", and, more significantly, designates the treble parts as "Dessus 1" and "Dessus 2".

The discovery of Telemann dance movements in several orchestral pastiche and compilation manuscripts of Group B both broadens the identifiable repertory of the Dresden Hofkapelle and suggests that this repertory may have been even richer in Telemann's music - especially with respect to overture-suites - than we can presently determine. Note in Table 1 that three hybrid suites beginning with Händel's overtures to the operas Amadigi di Gaula, Rodelinda, and Admeto continue with excerpts from three of Telemann's overture-suites for three oboes and strings: TWV 55:C6 (the remarkable "Sommeille"; movement 3 in Mus.2410-F-14), TWV 55:D15 (the "Rondeau" and "Réjouissance"; movements 3-4 in Mus.2410-F-26), and TWV 55:d3 (the "Menuet", "Gavotte", "Courante", "Air", "Loure", and "Canarie"; movements 2-6 in Mus.2410-F-29); the second of these

lino 2. do", and "Basse". All parts bear the title "Sonata" in Mus.2392-Q-84, whereas this title is lacking in the other two manuscripts ("Sonata" is erased on the bass part to Mus.2392-Q-85a).

31 Intriguingly, the agréments given for the trio in a pedagogical manuscript connected to Quantz largely correspond to those in the Berlin parts. For Quantz's ornaments, see Steven Zohn, Georg Philipp Telemann: Twelve Trios, Madison 2000, p. 173; and Winfried Michel and Harmann Teske, eds., Solfeggi pour la Flute Traversiere avec l'enseignement, Par Mons. Quantz, Winterthur 1978, pp. $55 \mathrm{f}$. Quantz's ornaments for the trio's third movement are similar to those found in Pisendel's parts. 
manuscripts also contains excerpts from an overture-suite by Johann Friedrich Fasch (FWV $\mathrm{K}: \mathrm{D} 21)$. None of the three Telemann overture-suites is otherwise transmitted in the Dresden collection. Additionally, two orchestral compilation manuscripts (Mus.2-N-13,10 and 11) consisting, respectively, of forty-two and twenty-two numbered movements used as theatrical entractes include excerpts from seven more Telemann overture-suites: TWV 55:Es4, e10, F10, G6, g7, A8, and h4. ${ }^{32}$ Three of these works - TWV 55:Es4, G6, and A8 - were previously unsuspected of having been performed by the Hofkapelle. ${ }^{33}$ That five of the seven (TWV 55:e10, G6, g7, A8, and h4) are concertouvertures featuring a single violin or wind soloist speaks to the well-known predilection for concertante writing among Pisendel and his Dresden colleagues. ${ }^{34}$ Also included in Mus.2-N-13,10 is an orchestral arrangement of the "Hornpipe" movement from TWV 41:g4, presumably taken directly from Der getreue Music-Meister.

There is good reason to believe that Mus.2-N-13,10 contains several additional works by Telemann. In an unintended gift to posterity, Pisendel labelled each movement in the "Violino Primo Conc:" part with its composer's initial: “T” (Telemann), "F” (Fasch), "P" (Pisendel), or "S" (Johann Christoph Schmidt). The arrangement of the G minor hornpipe even bears the double initials " $\mathrm{T}$ " and "P" to indicate composer and arranger. ${ }^{35}$ Besides the movements listed in Table 1, six more are labelled with a "T": an "Entrée", "Rigaudon", and "Air" in D major (Nos. 1-3, scored for unison violins doubled by two oboes, "haute contre", viola, and continuo); an "Air" and "Rejouissance" in G major (Nos. 9-10, scored for two oboes, two violins, viola, "haute contre" alternately doubling violin 2 and viola, and continuo); and a "Prelude. Vitement" in D minor (No. 35, scored for two violins doubled by two oboes, viola doubled by "haute contre", and continuo). None of these movements, the first violin parts to which may be seen in Illustrations 4-6, belongs to any previously known work by Telemann. Since there is no reason to doubt Pisendel's attributions, we may surmise that this music was drawn from otherwise lost Telemann overture-suites in D major, D minor, and G major. ${ }^{36}$

As it happens, the $\mathrm{D}$ major and $\mathrm{G}$ major works may in fact survive in more complete form in the Dresden collection. A set of parts to an anonymous pastiche suite in D major and G major, copied by Pisendel and "Schreiber P2" on unwatermarked paper and contemporary with the Group A manuscripts (Mus.2-N-20,8), begins with a "Sinfonia. Allegro" concerto movement - an odd

32 In Mus.2-N-13,10, some of the parts are labelled "Entracte". The $c .1765$ title pages to both manuscripts identify the contents as Pieçen von verschiedenen Meistern. Mus.2-N-13,11 includes fragmentary "Violino Primo" and "Flauto Traversiero Secondo" parts that break off after movements 5 and 6, respectively. Both contain sketches in the hand of Pisendel, and the latter bears his initial "P". On the larger repertory of Dresden entr'actes, see Voss, Teilsammlungen und ihre Identifizierung 2012 (as footnote 5), pp. 44-46.

33 The discovery that TWV 55:G6 was known at the Dresden court increases the likelihood that the suite for solo violin and strings, TWV 55:G13, the only known source for which is the lost set of parts Mus.2392-O-2, was in fact the same work. As reported by Horst Büttner, Das Konzert in den Orchestersuiten Georg Philipp Telemanns. Mit einer Bibliographie der Orchestersuiten, Wolfenbüttel / Berlin 1935, p. 80 (Suite B3), 55:G13 had the same scoring and movement sequence as 55:G6.

34 On the concertouverture as a subtype, see Zohn, Music for a Mixed Taste 2008 (as footnote 8), pp. 41-56.

35 Only two movements, No. 37 (TWV 55:F10/ii) and No 42 (55:g7/iii), lack initials. Additionally, No. 4 is unattributed ("N.N."). It is worth noting here that the fragmentary "Violino Primo" part of Mus.2-N-13,11 (see footnote 32 above) also identifies several movements by their composers' initial, including a "T" for No. 3 (55:Es4/iv).

36 If these identifications prove to be correct, then the 'new' works may be assigned the catalogue numbers TWV 55:D27, d4, and G14. 
replacement for the expected French overture and stylistically suspect as a work of Telemann (Ill. 7). ${ }^{37}$ The suite continues with the three movements from Mus.2-N-13,10 ("Aria", after which the "Sinfonia" is repeated; "Entrée"; and "Rigaudon") and then a "Menuet" and "Harlequinade", also in D major. These last two movements, which in stylistic terms are plausible as authentic works by Telemann, are shown in Illustrations 8-9. Thus it appears that at least five movements of the D major suite survive. The first of the three G major movements in Mus.2-N-20,8 is the "Bourrée" from TWV 55:G6 (Ill. 9); unlike the version in Mus.2-N-13,10, only the first of the paired dances is given. The following two movements, a "Gavotte en Rondeau" and a "Passepied" (Ill. 10), have no known concordances, and because they too are stylistically plausible as works by Telemann, we may tentatively assign them to the same lost G major suite as the "Air" and "Rejouissance" of Mus.2-N-13,10.

Also possibly belonging to a lost Telemann work is a binary allegro movement in E flat major for violin and continuo. The manuscript, which also includes an unidentified violin sonata in $\mathrm{F}$ major, was copied by Pisendel on paper with watermark W-Dl-068 (Zohn 13) Z / ZITTAV (Mus.2-R-8,85; also contemporary with the Group A manuscripts). In the upper right-hand corner of the page with the E flat movement, Pisendel has written "Mel.", which may be an abbreviation for Telemann's anagram, "Melante" (Ill. 11). ${ }^{38}$ The paper type suggests that Pisendel may have copied the two works prior to his arrival in Dresden in 1712.

Finally, let us consider Pisendel's parts to the loures of TWV 55:Es4 and G6. As shown in Illustration 12, the E flat movement is graced with a number of agréments not found in concordant sources. Because these ornaments are in Morgenstern's hand, it is uncertain whether they stem from Pisendel (the Konzertmeister did, however, copy them into the "Oboe Primo R[ipieno]" part). In the G major movement, Pisendel added his own diminution-style ornaments to the second of two dances, using what Manfred Fechner has aptly named "Pünktchennotierung" (Ill. 13). ${ }^{39}$ (Here the binary-form repeats are omitted, and only the second half of the first dance is recapitulated.) This movement is just the fifth known example of Pisendel adding such free ornamentation to a work of Telemann, and the only one among them featuring Italianate embellishments applied to a work in the French style a delightful instance of the Konzertmeister's celebrated vermischter Geschmack. ${ }^{40}$

37 See the manuscript's listing in Sylvie Reinelt, Die Ordnung von Schranck No: II - tabellarische Übersicht, in: Schranck No: II 2012 (as footnote 5), p. 179.

38 As noted in Reinelt, Die Ordnung von Schranck No: II 2012 (as footnote 5), p. 169.

39 Manfred Fechner, "Improvisationsskizzen und ausnotierte Diminutionen von Johann Georg Pisendel, dargestellt an in Dresden handschriftlich überlieferten Konzerten von Johann Friedrich Fasch und Johann Gottlieb Graun", in: Zu Fragen der Improvisation in der Instrumentalmusik der ersten Hälfte des 18. Jahrhunderts. Konferenzbericht der 7. Wissenschaftlichen Arbeitstagung Blankenburg/Harz, 29. Juni bis 1. Juli 1979, Blankenburg 1980, pp. 35-55 (Studien zur Aufführungspraxis und Interpretation der Musik des 18. Jahrhunderts. 10); idem, “Einige Anmerkungen zu einem Berliner Violinkonzert von Johann Gottlieb Graun und seiner Dresdner Realisierung durch Johann Georg Pisendel", in: Die Entwicklung des Solokonzerts im 18. Jahrhundert. Konferenzbericht der 10. Wissenschaftlichen Arbeitstagung Blankenburg/Harz, 25. Juni bis 27. Juni 1982, edited by Eitelfriedrich Thom, Blankenburg 1983, pp. 39-46 (Studien zur Aufführungspraxis und Interpretation der Musik des 18. Jahrhunderts. 20). See also Karl Heller, "Zu einigen Aspekten der solistischen Improvisation im Instrumentalkonzert des frühen 18. Jahrhunderts", in: Zu Fragen des Instrumentariums, der Besetzung und der Improvisation in der ersten Hälfte des 18. Jahrhunderts. Konferenzbericht der 3. Wissenschaftlichen Arbeitstagung Blankenburg/Harz, 28.-29. Juni 1975, Blankenburg 1976, vol. 2, pp. 80-87 (Studien zur Aufführungspraxis und Interpretation der Musik des 18. Jahrhunderts. 2).

40 The other examples of Pisendel's "Pünktchennotierung" in music by Telemann are found in Mus.2392-O-30 (TWV 54:D2), ...Q-6 (42:D1), ...Q-11 (42:A8), and ...Q-80 (42:G9). 


\section{Who Wrote the Manuscripts of "Schreiber P"?}

Let us turn now to the particularly interesting case of "Schreiber P", whose hand appears in thirteen manuscripts in Group A, and his relationship to "Schreiber D" (Morgenstern). ${ }^{41}$ We know from Manfred Fechner's investigations that "Schreiber P's" Dresden activities were concentrated around 1720 and closely connected to Pisendel. Fechner has also observed that "Schreiber P" used two distinct forms of bass clef; hence he distinguishes between "P1" and "P2" forms of handwriting, though without establishing a chronological relationship between the two. ${ }^{42}$ Ortrun Landmann has taken a different view of the manuscripts attributed by Fechner to "Schreiber P", suggesting that they were instead copied by Johann Gottlieb Morgenstern before about 1725, by which time the violist's script had adopted the characteristics described in detail by Fechner, who detects no fewer than eight handwriting stages spanning the period $1725-1755 .{ }^{43}$ In her most recent study of the Dresden copyists, Landmann has attempted to document Morgenstern's scribal activities during the period 1718 to 1725 , tracing his rapidly evolving penmanship through a number of manuscripts, including those assigned by Fechner to "Schreiber P". ${ }^{4}$ I have listed all of the sources in question in Table 2. Note here that the "Scribe" column conflates the identifications of Fechner ("P1" and "P2") and Landmann (Morgenstern handwriting stages "a", "b" and "c"). Some entries include identifications from both scholars, and identifications in brackets are my own.

My interest in re-examining the question of "Schreiber P"'s identity stems from Landmann's claim that a set of parts to Telemann's well known triple concerto for flute, oboe d'amore, and viola d'amore, TWV 53:E1 (Mus.2392-O-32), listed in Group D of Table 1 and again in Table 2, was copied by Morgenstern during his handwriting stage " $b$ ", which encompasses the "Schreiber $\mathrm{P}$ " manuscripts. ${ }^{45}$ We shall return to this concerto in due course, but let us first consider two other manuscripts, both credited by Fechner to "Schreiber P". Illustrations 14-17 show handwriting samples of "Schreiber P1" and "P2". (Not shown in these illustrations are C clefs, which have similar, though not identical, forms.) It should be clear from even a quick comparison between them that there are many graphical features in common, especially the form of the treble clefs (Ills. 14 and 16). But there are also some fundamental differences in both musical and textual notation. Notice that in Illustration 16, the upper half of "P2"'s clefs lean toward the right, whereas in Illustration 14 , "P1" keeps them perfectly vertical. The bass clefs, as already mentioned, are very different from one another (Ills. 15 and 17), and other clear divergencies between the notation of "P1" and "P2" include the "C"s for time signatures, the lengths of note stems (which are longer in "P1"), the "V"s in "Violino", and the page turn indications ("SV" in "P1" vs. "VS" in "P2"). One might reasonably argue that all of these distinctions can be explained by a gradual development of "Schreiber P"'s handwriting over the years, not unlike the evolution noted by Fechner in the script of "Schreiber

41 Some of my views regarding the physical and chronological relationships between the "Schreiber P1" and "P2" handwriting forms were shaped by discussions during late 2003 with Joshua Rifkin, whose insights I gratefully acknowledge here. A useful summary of previous research on "Schreiber P" is provided by Eckhardt, Über die Kopisten 2012 (as footnote 5), pp. $216 \mathrm{f}$.

42 Fechner, Studien 1999 (as footnote 1), pp. 134f. and 194-197.

43 Landmann, Telemann 1983 (as footnote 1), p. 146 and Figs. 24-25. Fechner, ibid., pp. 91-124 and 159-186.

44 Landmann, Drei Studien 22010 (as footnote 2), pp. 163-167.

45 Ibid, p. 166. 
D”. The difficulty with this argument, however, is that we are talking about a relatively short time frame, perhaps as little as five years.

What most seriously undermines the connection between "P1" and "P2" is the relationship of stems to noteheads: in the "P1" manuscripts, downward pointing stems on quarter notes and smaller values are drawn to the right of the notehead, and stems on half notes are drawn to the centre; in "P2" manuscripts, on the other hand, downward stems are drawn to the left on smaller note values, and to the right on half notes. This distinction strikes me as more significant than the others mentioned above, for stem placement is a sort of scribal habit that seems less easily broken, especially within a narrow span of time. In the absence of transitional handwriting samples, then, we must conclude either that two people are responsible for "Schreiber P"'s manuscripts, or that we are dealing with a single scribe copying in two widely separated temporal periods - a possibility, however, that the watermark evidence argues against.

As for the chronological range of "Schreiber P"'s activities, we know that "P1" added doublets to Pisendel's parts for Telemann's violin concerto TWV 51:B1 (Mus.2392-O-58), which the violinist prepared around the time of the work's composition in September 1719. Precisely when these doublets were written cannot be determined, though to judge from the paper, it must have been no later than the mid-1720s. "Schreiber P1"'s doublets to a violin concerto by Francesco Maria Cattaneo are unlikely to have been copied prior to 1721, when the violinist-composer joined the private Kapelle of Count Jakob Heinrich von Flemming in Dresden. But they may also date from around 1726, the year in which Cattaneo joined the Dresden Hofkapelle. So at present, it seems that "P1"'s activities fall within the chronological poles of 1719 and the mid-to-late 1720s. We have even less to go on for "Schreiber P2", who copied on unwatermarked paper, or on paper with the early (pre1725) watermarks W-Dl-081 (Zohn 10) and W-Dl-082 (Zohn 9) HB.

Could either "P1" or "P2" be Morgenstern, as Landmann has suggested? To answer this question, we must consider some of the other manuscripts listed in Table 2, the first four in particular. The copy of Vivaldi's violin concerto RV 314 (Mus.2389-O-70a) represents, according to Landmann, the earliest known stage of Morgenstern's writing, one immediately preceding the " $b$ " or "Schreiber P" stage. ${ }^{46}$ As Illustrations 18-19 show, the treble clef bears a resemblance to that of "P1", and the bass clef to that of "P2". However, these are, at least to my eyes, merely passing resemblances. And they are in any case outweighed by the many substantial differences, which extend to text, time signatures, quarter rests, flourishes at the end of movements, page turn indications, spacing of notes, and the placement of downward stems, which - in contrast to both "P1" and "P2" - are always drawn to the right of the notehead. In short, it is difficult to see how the copyist of RV 314 could change his writing so dramatically in just a few years.

Next, in Illustration 20, we see the "Basso" part to an overture-suite by Johann Christoph Schmidt (Mus.2154-N-1, 1), an example of what Landmann regards as Morgenstern's handwriting stage " $b$ ". Here the resemblance with the script of "Schreiber P2" is clearer. But there are some significant differences, such as the form and placement of the bass clef and the " $\mathrm{C}$ " of the time

46 As Landmann shows (Drei Studien 2010 [as footnote 2], p. 435, Fig. III.123a), the copyist of the title page to this manuscript left his monogram "J.G. M." in the lower right-hand corner. But even assuming that the monogram stands for "Johann Gottlieb Morgenstern", it is unclear whether the copyist of the title page was also responsible for the music. 
signature, and the hand has been identified by the project "Die Instrumentalmusik der Dresdner Hofkapelle zur Zeit der sächsisch-polnischen Union" as belonging to Lindner. Another example of Morgenstern's handwriting stage " $b$ " is furnished by Illustration 21, from a manuscript containing a Partie by Schmidt (Mus.2154-N-3). Here we have a problem, though, for other aspects of handwriting aside, downward stems are always drawn to the right of the notehead. This contrasts with the practices we observed in the first Schmidt manuscript and in the examples of "Schreiber P1" and "P2", all of which supposedly belong to the same handwriting stage. In fact, the manuscript was copied by Johann Wolfgang Schmidt.

With Illustrations 22-23 (from the Zelenka sinfonia ZWV 189; Mus.2358-N-9a), we reach the handwriting stage that Landmann considers a "Zwischenform" on the way toward Fechner's "D1" stage, which is shown in Illustration 24 (from Telemann's trio TWV 42:D1; Mus.2392-Q-6). It would also have to be considered transitional to Morgenstern's "D0" stage, recently identified by Wolfgang Eckhardt and shown in Illustration 25 (from Telemann's overture-suite TWV 55:g8; Mus.2392-O-41). The two "D0" manuscripts (Mus.2392-N-30 and ...O-41 in Group B of Table 1) cannot be earlier than 1728, for they are copied on paper with watermark W-Dl-043 (Zohn 2), which includes this date as a countermark. Despite the significant differences between Illustrations 22-25 in terms of clef forms and text, the musical script is remarkably similar. Note, however, that the copyist of the Zelenka sinfonia draws downward stems to the right of half notes, whereas "Schreiber D0/D1" (and all subsequent handwriting stages) draws downward stems from the middle of the notehead almost without exception.

At this point it is worth summarizing our findings. First, "Schreiber P1" and "P2" are most likely two people, unless we are willing to place a single "Schreiber P"'s activities over a longer time period than currently accepted. Second, there is little reason to think that the copyist of RV 314 (Ills. 18-19) is either "P1" or "P2". And third, it seems possible - but far from certain - that the copyist of Zelenka's sinfonia (Ills. 22-23) is in fact Morgenstern. A good deal of the evidence for these assertions comes from the relationship of note heads to stems, an aspect of musical script that seems less mutable over time than, for example, clefs. To be sure, if we imagine all of these manuscripts to have been copied by the same person, then we must also imagine him changing the way he draws note stems every year or two - an unlikely scenario, to say the least.

So far the stakes have been relatively low, for the authenticity and chronology of the music in question is scarcely affected by attaching this or that name to its copyist. But as I said, my initial interest in "Schreiber P" and his possible connection to "Schreiber D" stemmed from the copy of Telemann's triple concerto TWV 53:E1. In this case, it would make a difference in the music's chronology if the Dresden parts proved to be in Morgenstern's “Schriftform b". The concerto, as I and several others have noted, exhibits stylistic characteristics associated with the music Telemann composed at Hamburg after $1725 .{ }^{47}$ Assigning this work to the mid-to-late 1720 s is consistent with its other known sources: a c. 1730 score by Darmstadt "Schreiber B" (possibly Johann Gottfried Vogler) and a set of parts copied by Christoph Graupner between 1726 and 1730 (D-DS: Mus. Ms.1033/43a and 43b). Needless to say, the received wisdom about the concerto would be called into question by a Dresden set of parts copied no later than the early 1720 s.

Although the images in the final two illustrations are admittedly difficult to read, it should 
be clear enough that we are dealing with two distinct copying hands (S-Dl-026 and 033). Illustration 26 shows the two unidentified scribes juxtaposed in the "Violino Primo" part, and Illustration 27 shows them in the "Cembalo" part. The presence of two hands in the manuscript has already been observed by both Landmann and Fechner, though most recently Landmann has assigned the entire manuscript to Morgenstern, noting that the text and musical script are "sehr uneinheitlich" ${ }^{48}$ In fact, the first copyist in Illustrations 26 and 27 does write his clefs and rests in a manner very similar to Morgenstern, as is readily seen from a comparison with Illustrations 24 and 25. However, he also writes his downward stems on quarter and eighth notes to the left of the notehead, and stems to half notes in the center - a combination that we have not yet seen in any of the sources attributed to "Schreiber P" or Morgenstern. Another important piece of evidence indicating that the manuscript is not the work of Morgenstern - or indeed of any Dresden scribe - comes from the two paper types. ${ }^{49}$ Paper with watermark W-Dl-195 (Zohn 35) IDB, originating at the mill owned by Melchior Bierdimpfel in Röthenbach bei Lauf, is not found anywhere else in the Dresden collection. The watermark's design (a rose surmounted by a six-pointed star, with the letters "MBD” attached to the flower's stem) is similar to those found in four Telemann manuscripts prepared by Darmstadt "Schreiber B". ${ }^{50}$ Watermark W-Dl-313, a man turning a stone (Steinwender) in a shield or cartouche with a countermark of a duck (Ente) in a cartouche, is a play on the paper's origin at the Wendelstein mill operated over many years by members of the Endter family. Similar watermarks are again found in the Darmstadt Telemann collection. ${ }^{51}$ Thus we may confidently place the origin of Mus.2392-O-32 outside of Dresden (perhaps specifically at the Darmstadt court) and continue to assign Telemann's concerto to the mid-to-late 1720s.

As vexing as they may be, the uncertainties inherent in tracing the development of a particular scribe's handwriting, in determining the chronology and provenance of undated manuscripts, and in providing attributions for anonymous works ultimately reflect the complexity and variety of the Dresden Hofkapelle's activities. This latest view of the Telemann sources has moved us a few steps closer toward fully appreciating which of the composer's works belonged to the court's repertory, when and by whom they were copied and performed, and how their reception changed over time. But we may also expect that many present assumptions about these and other aspects of the Dresden music collection will need rethinking as the contents of "Schrank II" become better known and are viewed from fresh perspectives.

48 Landmann, Telemann 1983 (as footnote 1), p. 125; Fechner, Studien 1999 (as footnote 1), p. 230; and Landmann, Drei Studien 2010 (as footnote 2), p. 166 (from which the above quotation is taken).

49 On the identification and origins of these paper types, see Wolfgang Eckhardt, "Über die in den Manuskripten aus dem Schranck No: II verwendeten Papiersorten”, in: Schranck No: II 2012 (as footnote 5), pp. $244 \mathrm{f}$.

50 D-DS: Mus.ms.1033/12, 1034/30a, 1042/12, and 1042/23. The watermark in this last manuscript is illustrated in Steven Zohn, The Ensemble Sonatas of Georg Philipp Telemann: Studies in Style, Genre, and Chronology, Ph.D. diss., Cornell University 1995, p. 629.

51 The manuscripts in question are too numerous to list here, but the watermarks found in them either pair the main design of a man turning a stone with the duck countermark, or show the duck alone. Illustrations of both varieties are provided in Zohn, The Ensemble Sonatas, ibid, pp. $619 \mathrm{f}$. 
Table 1. Instrumental Works by Telemann in Eighteenth Century Dresden Manuscript Copies

Principal sources for copyists include Landmann, Telemann 1983 (as footnote 1), Fechner, Studien 1999 (as footnote 1), and Landmann, Drei Studien ${ }^{2} 2010$ (as footnote 2). Copyist and watermark numbers beginning "S-Dl" and "W-Dl" are those assigned by the research project "Die Instrumentalmusik der Dresdner Hofkapelle zur Zeit der sächsisch-polnischen Union. Erschließung, Digitalisierung und Internetpräsentation". Watermark numbers in parentheses derive from Zohn, Paper 2000 (as footnote 1), and are designated Zohn ... Letters, words or digits featured in the watermarks are added in italics.

\section{A. Copied c. 1710-1725 (73 works in 77 manuscripts)}

\begin{tabular}{|c|c|c|c|c|}
\hline$T W V$ & Mus.2392-... & Copyist(s) & Watermark(s) & $\begin{array}{l}\text { Non-Dresden } \\
\text { Concordances }\end{array}$ \\
\hline 41:fis2 & ...R-3 & Schreiber v (Weimar?) & W-Dl-226 (Zohn 25) IV & \\
\hline 41:g10 & $\ldots S-1$ & Pisendel & W-Dl-165 (Zohn 24) WR & \\
\hline 41:A7 & $\ldots \mathrm{R}-2$ & S-Dl-013 (central German?) & $\begin{array}{l}\text { W-Dl-074 (Zohn 13) } \\
\text { Z/ ZITTAV }\end{array}$ & \\
\hline 42:C3 & $\ldots \mathrm{Q}-1$ & S-Dl-087 & W-Dl-044 (Zohn 15) ES & \\
\hline $42: c 4$ & ...Q-78 & Pisendel, unknown & W-Dl-027 (Zohn 14) & D-DS, D-WD \\
\hline $42: c 8$ & $\ldots Q-25$ & S-Dl-087 & W-Dl-044 (Zohn 15) ES & \\
\hline 42:D4 & $\ldots \mathrm{Q}-32 \mathrm{a}$ & Pisendel & W-Dl-103 (Zohn 5b) IGS & $\begin{array}{l}\text { D-DS, S-Skma; Six } \\
\text { Sonates }(1731 / 33)\end{array}$ \\
\hline 42:D13 & $\ldots Q-8$ & Lindner & W-Dl-057 ES & \\
\hline 42:D14 & ...Q-9 & S-Dl-087 & W-Dl-044 (Zohn 15) ES & \\
\hline 42:D15 & $\begin{array}{l}\ldots \mathrm{Q}-31 \\
\ldots \mathrm{Q}-58\end{array}$ & $\begin{array}{l}\text { G. B. Vivaldi } \\
\text { Pisendel }\end{array}$ & $\begin{array}{l}\text { W-Dl-337 (Zohn } 32 \text { or 33?) } \\
\text { W-Dl-081 (Zohn 10) }\end{array}$ & \\
\hline 42:D16 & $\begin{array}{l}\ldots \mathrm{Q}-85 \mathrm{a} \\
\ldots \mathrm{Q}-85 \mathrm{~b} \\
\end{array}$ & $\begin{array}{l}\text { Pisendel } \\
\text { S-Dl-087 }\end{array}$ & $\begin{array}{l}\text { W-Dl-027 (Zohn 4) } \\
\text { W-Dl-018? }\end{array}$ & D-Bsa, D-ROu \\
\hline 42:d2 & ...Q-41a & Pisendel & W-Dl-021 (Zohn 5b) IGS & $\begin{array}{l}\text { D-DS, S-Skma; Six } \\
\text { Sonates }(1731 / 33)\end{array}$ \\
\hline 42:d6 & $\ldots \mathrm{Q}-23$ & Schreiber v (Weimar?) & $\begin{array}{l}\text { W-Dl-072 (Zohn 13) } \\
\text { Z/ ZITTAV }\end{array}$ & D-DS \\
\hline 42:d9 & $\ldots Q-15$ & S-Dl-123 & W-Dl-152 (Zohn 11) & \\
\hline 42:d11 & $\ldots Q-84$ & Pisendel, unknown & W-Dl-027 (Zohn 4) & D-Bsa, D-WD \\
\hline 42:e7 & $\begin{array}{l}\ldots \mathrm{Q}-36 \\
\ldots \mathrm{Q}-37 \\
\end{array}$ & $\begin{array}{l}\text { Pisendel } \\
\text { G. B. Vivaldi }\end{array}$ & $\begin{array}{l}\text { W-Dl-081 (Zohn 10) } \\
\text { W-Dl-107 (Zohn 33) }\end{array}$ & D-DS, $\mathrm{ROu}$ \\
\hline 42:F12 & $\ldots Q-45$ & Pisendel & W-Dl-154 ff? (Zohn 14) & \\
\hline 42:F13 & ...Q-46 & unknown & W-Dl-036 (Zohn 5a or b) & \\
\hline 42:G3 & $\ldots \mathrm{Q}-28 \mathrm{a}$ & Pisendel & W-Dl-154 ff (Zohn 14) & $\begin{array}{l}\text { D-DS, S-Skma; Six } \\
\text { Sonates }(1731 / 33)\end{array}$ \\
\hline 42:G9 & ...Q-80 & Pisendel & W-Dl-081? (Zohn 9?, 10?) & D-DS \\
\hline 42:G11 & $\ldots Q-5$ & Lindner & W-Dl-152 (Zohn 11) & \\
\hline 42:G12 & $\ldots \mathrm{Q}-27 \mathrm{~b}$ & Pisendel & W-Dl-081 (Zohn 10) & Six Sonates $(1731 / 33)$ \\
\hline 42:g12 & $\ldots Q-49$ & Schreiber P2 & None & \\
\hline 42:g14 & $\ldots Q-51$ & Pisendel & W-Dl-154 ff? (Zohn 14) & \\
\hline
\end{tabular}




\begin{tabular}{|c|c|c|c|c|}
\hline$T W V$ & Mus.2392-... & Copyist(s) & Watermark(s) & $\begin{array}{l}\text { Non-Dresden } \\
\text { Concordances }\end{array}$ \\
\hline 42:g15 & ...Q-57 & Schreiber P2 & W-Dl-081 (Zohn 10) & $\mathrm{D}-\mathrm{ROu}$ \\
\hline 42:A2 & ...Q-33a & Pisendel & W-Dl-021 (Zohn 5b) IGS & $\begin{array}{l}\text { D-DS, S-Skma; Six } \\
\text { Sonates }(1731 / 33)\end{array}$ \\
\hline 42:A8 & ...Q-11 & Pisendel, unknown & W-Dl-038 (Zohn 5b) IGS & D-DS \\
\hline 42:A9 & ...Q-55 & G. B. Vivaldi & W-Dl-106 (Zohn 32) A & $\mathrm{D}-\mathrm{B}, \mathrm{DS}, \mathrm{ROu} ; \mathrm{B}-\mathrm{Bc}$ \\
\hline 42:A13 & ...Q-13 & S-Dl-087 & W-Dl-044 (Zohn 15) ES & \\
\hline $42: a 5$ & ...Q-18 & S-Dl-013 (central German?) & $\begin{array}{l}\text { W-Dl-072 (Zohn 13) } \\
\text { Z/ ZITTAV }\end{array}$ & D-DS \\
\hline $42: \mathrm{h} 7$ & $\ldots \mathrm{Q}-21$ & S-Dl-013 (central German?) & $\begin{array}{l}\text { W-Dl-071 (Zohn 13) } \\
\text { Z/ ZITTAV } \\
\end{array}$ & \\
\hline 43:D6 & ...Q-29 & Schreiber P2 & W-Dl-081 (Zohn 10) & D-WD \\
\hline $43: \mathrm{d} 2$ & ...Q-22 & S-Dl-018 & W-Dl-178 (Zohn 12) PL & $\begin{array}{l}\text { D-DS; Quatrième livre de } \\
\text { Quatuors (after 1752) }\end{array}$ \\
\hline 43:e5 & ...Q-19 & Pisendel & W-Dl-027 (Zohn 14) & D-DS \\
\hline 43:G5 & $\ldots \mathrm{Q}-3$ & Lindner & W-Dl-152 (Zohn 11) & $\begin{array}{l}\text { Quatrième livre de } \\
\text { Quatuors (after 1752) }\end{array}$ \\
\hline 43:G6 & $\ldots \mathrm{Q}-77$ & Quantz & $\begin{array}{l}\text { W-Dl-075 (Zohn 13) } \\
\text { Z/ ZITTAV }\end{array}$ & D-Bsa, DS \\
\hline 43:G7 & $\ldots \mathrm{Q}-2$ & Pisendel & W-Dl-081 (Zohn 10) & D-DS, ROu, SWl \\
\hline 43:g4 & ...Q-82 & S-Dl-001 (Leipzig Anon. Vn) & W-Dl-082 (Zohn 9) $H B$ & \\
\hline 43:A4 & ...Q-10 & S-Dl-018 & W-Dl-082 (Zohn 9) $H B$ & $\begin{array}{l}\text { D-Bsa, DS; Quatrième } \\
\text { livre de Quatuors (after } \\
1752 \text { ) }\end{array}$ \\
\hline 43:A6 & ...N-6a & Pisendel & W-Dl-082 (Zohn 9) $H B$ & \\
\hline 43:a5 & ...Q-83 & Pisendel & W-Dl-027 (Zohn 4) & D-Bsa, DS \\
\hline $44: 11$ & $\begin{array}{l}\ldots \mathrm{Q}-14 \\
\ldots \mathrm{Q}-14 \mathrm{a} \\
\end{array}$ & $\begin{array}{l}\text { Pisendel } \\
\text { Schreiber C and Schreiber k }\end{array}$ & $\begin{array}{l}\text { none } \\
\text { W-Dl-001 }\end{array}$ & \\
\hline $44: 41$ & $\ldots \mathrm{O}-28$ & S-Dl-013 (central German?) & $\begin{array}{l}\text { W-Dl-071 (Zohn 13) } \\
\text { Z / ZITTAV }\end{array}$ & D-DS \\
\hline $44: 42$ & ...Q-76 & Lindner & $\begin{array}{l}\text { W-Dl-026? (Zohn 4) } \\
\text { W-Dl-082 (Zohn 9) HB }\end{array}$ & D-DS \\
\hline $51: \mathrm{d} 1$ & $\ldots \mathrm{Q}-47$ & S-Dl-013 (central German?) & $\begin{array}{l}\text { W-Dl-072 and } 074 \\
\text { (Zohn 13) Z / ZITTAV }\end{array}$ & D-DS \\
\hline 51:E3 & $\ldots \mathrm{O}-8$ & S-Dl-109 (J.C. Seyfert?) & W-Dl-259 & \\
\hline $51: \mathrm{F} 2$ & $\ldots \mathrm{O}-11$ & Pisendel, Schreiber P1 & $\begin{array}{l}\text { W-Dl-081 (Zohn 9) } \\
\text { W-Dl-256 }\end{array}$ & D-DS \\
\hline 51:G6a & ...O-57 & Pisendel & W-Dl-081? (Zohn 9?, 10?) & D-DS \\
\hline 51:G8 & $\ldots \mathrm{O}-3$ & Lindner & $\begin{array}{l}\text { W-Dl-031? } \\
\text { W-Dl-082 (Zohn 5?) } H B ?\end{array}$ & D-DS, SWl \\
\hline 51:g1 & $\ldots \mathrm{O}-17 \mathrm{a}$ & Schreiber v (Weimar?) & W-Dl-226 (Zohn 25) & D-DS, BWV 985 \\
\hline $51: B 1$ & $\begin{array}{r}\ldots \mathrm{O}-38 \\
\ldots \mathrm{O}-58\end{array}$ & $\begin{array}{l}\text { Telemann } \\
\text { Pisendel } \\
\text { Schreiber P1 }\end{array}$ & $\begin{array}{l}\text { (Zohn 5b) } \\
\text { W-Dl-021 (Zohn 5b) } \\
\text { W-Dl-019 (Zohn 5a) } \\
\end{array}$ & \\
\hline 52:D2 & $\ldots \mathrm{O}-27$ & Schreiber P2 & none & D-DS \\
\hline 52:D3 & $\ldots \mathrm{O}-4$ & Lindner, Schreiber u, unknown & $\begin{array}{l}\text { W-Dl-016?, } \\
\text { W-Dl-024 and } 031 \text { (Zohn } \\
5 \text { ?) } \\
\text { W-Dl-082 (Zohn 9) HB } \\
\text { W-Dl-361 }\end{array}$ & US-Wc \\
\hline
\end{tabular}




\begin{tabular}{|c|c|c|c|c|}
\hline$T W V$ & Mus.2392-... & Copyist(s) & Watermark(s) & $\begin{array}{l}\text { Non-Dresden } \\
\text { Concordances }\end{array}$ \\
\hline 52:Es1 & ...O-31a & Schreiber P2 & W-Dl-081 (Zohn 10) & D-SWl \\
\hline $52: \mathrm{e} 4$ & $\ldots \mathrm{O}-56$ & $\begin{array}{l}\text { Lindner, S-Dl-001 (Leipzig Anon. } \\
\text { Vn), } 123\end{array}$ & $\begin{array}{l}\text { W-Dl-026 and } 031 \text { (Zohn 4) } \\
\text { W-Dl-082 (Zohn 9) HB? }\end{array}$ & D-DS \\
\hline 52:G1 & $\ldots \mathrm{O}-36$ & Schreiber P1 & none & D-DS \\
\hline $52: G 2$ & $\begin{array}{l}\ldots \mathrm{O}-35 \mathrm{a} \\
\ldots \mathrm{O}-35 \mathrm{~b}\end{array}$ & $\begin{array}{l}\text { J.S. Bach, Pisendel, S-D-115 and } 117 \\
\text { Schreiber v (Weimar?) }\end{array}$ & $\begin{array}{l}\text { W-Dl-160 (20) A } \\
\text { W-Dl-071 (Zohn 13) } \\
\text { Z / ZITTAV } \\
\text { W-Dl-226 (Zohn 25) }\end{array}$ & D-DS, US-Wc \\
\hline 52:g1 & $\ldots \mathrm{O}-45$ & Pisendel & W-Dl-034 (Zohn 5b) & \\
\hline 52:A2 & $\ldots \mathrm{O}-37$ & Pisendel & W-Dl-021 (Zohn 5b) IGS & \\
\hline 52:a2 & $\ldots \mathrm{O}-20$ & Pisendel & $\begin{array}{l}\text { W-Dl-018, 019, } 031 \text { (Zohn } \\
\text { 5a and variant?) }\end{array}$ & \\
\hline 52:B1 & ...O-19 & Pisendel, Schreiber P2 & none & D-DS \\
\hline 53:D1 & $\ldots \mathrm{O}-18$ & Telemann & $\begin{array}{l}\text { W-Dl-184 (Zohn 27) } \\
\text { GEP or GFP } \\
\text { W-Dl-189 (Zohn 29) } \\
\text { T / TELNITZ }\end{array}$ & D-DS \\
\hline 53:h1 & $\ldots \mathrm{O}-22$ & Telemann & W-Dl-089 (Zohn 22) AD & D-DS \\
\hline $54: B 2$ & $\ldots \mathrm{O}-29$ & Schreiber P2 & none & \\
\hline 55:D14 & $\ldots \mathrm{O}-5$ & Pisendel & W-Dl-081 (Zohn 10) & D-DS \\
\hline $55: e 10$ & ...O-23 & Schreiber P2 & W-Dl-081 (Zohn 10) & \\
\hline 55:F13 & ...O-10a & S-Dl-118 and 120 & $\begin{array}{l}\text { W-Dl-248 (Zohn 18?) RSG } \\
\text { W-Dl-094 (Zohn 26) } \\
\text { AM or } M A\end{array}$ & \\
\hline $55: G 2$ & $\ldots \mathrm{N}-3$ & Schreiber P2 & W-Dl-081 (Zohn 10) & D-DS \\
\hline 55:G6/iii & Mus.2-N-20,8 & Pisendel, Schreiber P2 & none & D-DS \\
\hline 55:g7 & ...O-16a & S-Dl-118 & W-Dl-248 (Zohn 18) RSG & \\
\hline $55: B 9$ & $\ldots \mathrm{N}-9$ & Lindner & W-Dl-082 (Zohn 9) $H B$ & \\
\hline 55:B11 & $\ldots \mathrm{O}-34$ & Telemann & W-Dl-162 (Zohn 23) & \\
\hline 55:h1 & $\ldots \mathrm{O}-40$ & S-Dl-123? (Lindner circle?) & $\begin{array}{l}\text { W-Dl-152 (Zohn 11) } \\
\text { W-Dl-157 (Zohn 19) CVC }\end{array}$ & D-DS, D-Rp \\
\hline
\end{tabular}




\section{B. Copied c. 1725-1735 (73 works in 67 manuscripts)}

\begin{tabular}{|c|c|c|c|c|}
\hline$T W V$ & Mus.2392-... & Copyist(s) & Watermark(s) & Non-Dresden Concordances \\
\hline $41: c 2$ & $\ldots \mathrm{R}-8$ & Grundig (A3) & W-Dl-001 (Zohn 6) IGS & Neue Sonatinen $(1730 / 31)$ \\
\hline 41:g4/iii & $\begin{array}{l}\text { Mus.2-N-13,10 } \\
(34)\end{array}$ & $\begin{array}{l}\text { Grundig (A1), Morgenstern } \\
\text { (D1), Pisendel }\end{array}$ & $\begin{array}{l}\text { W-Dl-001 (Zohn 6) IGS } \\
\text { W-Dl-041 and } 042 \text { (Zohn } \\
\text { 1) W-Dl-222 }\end{array}$ & $\begin{array}{l}\text { Der getreue Music-Meister } \\
(1728)\end{array}$ \\
\hline $41: a 4$ & $\ldots \mathrm{R}-9$ & Grundig (A3) & W-Dl-001 (Zohn 6) IGS & Neue Sonatinen $(1730 / 31)$ \\
\hline 41:h4 & $\ldots \mathrm{R}-7$ & Grundig (A3) & W-Dl-001 (Zohn 6) IGS? & Musique de table (1733) \\
\hline $42: \mathrm{cl} / \mathrm{i}-\mathrm{ii}$ & $\ldots \mathrm{Q}-44 \mathrm{~b}$ & Morgenstern (D4) & W-Dl-001 (Zohn 6) IGS & $\begin{array}{l}\text { D-DS, S-Skma; Six Sonates } \\
(1731 / 33)\end{array}$ \\
\hline $42: \mathrm{c} 2$ & ...Q-79 & Grundig (A1) & W-Dl-263 & $\begin{array}{l}\text { Essercizii musici } \\
(1726)\end{array}$ \\
\hline 42:D1 & $\ldots Q-6$ & Morgenstern (D1) & W-Dl-041 (Zohn 1) & Six Trio (1718) \\
\hline $\begin{array}{l}\text { 42:D2-3, d1, } \\
\text { E1, G1, A1 }\end{array}$ & $\ldots \mathrm{Q}-4$ & $\begin{array}{l}\text { Grundig (A3), Morgenstern } \\
\text { (D3 or } 4)\end{array}$ & W-Dl-001 (Zohn 6) IGS & $\begin{array}{l}\text { III Trietti methodichi e III } \\
\text { Scherzi (1731) }\end{array}$ \\
\hline 42:D12 & $\ldots \mathrm{Q}-7$ & Schreiber a & W-Dl-054 (Zohn 16) ES & \\
\hline $42: \mathrm{d} 8$ & $\ldots \mathrm{Q}-24$ & Schreiber a & W-Dl-054 (Zohn 16) ES? & D-DS \\
\hline 42:Es1 & $\begin{array}{l}\ldots \mathrm{Q}-17 \\
\ldots \mathrm{Q}-35 \\
\end{array}$ & $\begin{array}{l}\text { Grundig (A3) } \\
\text { S-D1-030 (Darmstadt?) }\end{array}$ & $\begin{array}{l}\text { W-Dl-001 (Zohn 6) IGS } \\
\text { W-Dl-192 (Zohn 34) } \\
\end{array}$ & Musique de table (1733) \\
\hline $42: \mathrm{e} 1 / \mathrm{i}-\mathrm{ii}$ & $\ldots \mathrm{Q}-44 \mathrm{~b}$ & Morgenstern (D4) & W-Dl-001 (Zohn 6) IGS & $\begin{array}{l}\text { D-DS, S-Skma; Six Sonates } \\
(1731 / 33)\end{array}$ \\
\hline $42: \mathrm{e} 9$ & $\ldots \mathrm{Q}-20$ & Schreiber a & W-Dl-054 (Zohn 16) ES & D-DS \\
\hline $42: g 5$ & $\ldots \mathrm{Q}-48$ & Grundig (A1) & W-Dl-041 (Zohn 1) & $\begin{array}{l}\text { Essercizii musici } \\
(1726)\end{array}$ \\
\hline 42:A13 & $\ldots \mathrm{Q}-12$ & Schreiber a & W-Dl-054 (Zohn 16) ES & \\
\hline $42: B 6$ & $\ldots \mathrm{N}-10$ & $\begin{array}{l}\text { Grundig (late), Morgenstern } \\
\text { (D3) }\end{array}$ & $\begin{array}{l}\text { W-Dl-002 (Zohn 1) Dres- } \\
\text { den JG Schuchart } \\
\text { W-Dl-041 (Zohn 1) }\end{array}$ & D-DS \\
\hline 43:C1 & $\ldots \mathrm{N}-1$ & Morgenstern (D2 and 4) & $\begin{array}{l}\text { W-Dl-041 and } 042 \text { (Zohn } \\
\text { 1) }\end{array}$ & $\begin{array}{l}\text { D-DS; Quatrième livre de } \\
\text { Quatuors (after 1752) }\end{array}$ \\
\hline 43:D1 & ...Q-30 & Grundig (A1) & W-Dl-041 (Zohn 1) & Quadri (1730) \\
\hline 43:D7 & $\ldots Q-56$ & Grundig (A1) & none & \\
\hline $\begin{array}{l}\text { 43:Es1 } \\
\text { 43:Es1/i-ii }\end{array}$ & $\ldots \mathrm{N}-12$ & $\begin{array}{l}\text { Pisendel, Grundig (A1) } \\
\text { Morgenstern (D1) }\end{array}$ & \begin{tabular}{|l} 
none \\
W-Dl-001 (Zohn 6) IGS \\
\end{tabular} & D-Bsa, D-DS \\
\hline 43:e1 & ...Q-38 & Grundig (A1) & W-Dl-041 (Zohn 1) & Quadri (1730) \\
\hline $43: \mathrm{e} 5 / \mathrm{i}$ & $\ldots \mathrm{N}-17$ & Morgenstern (D4) & W-Dl-001 (Zohn 6) IGS & D-DS \\
\hline 43:G1 & ...Q-26 & Grundig (A1) & W-Dl-041 (Zohn 1) & Quadri (1730) \\
\hline 43:G5 & $\ldots Q-3$ & Morgenstern (D4) & W-Dl-001 (Zohn 6) IGS & $\begin{array}{l}\text { Quatrième livre de Quatuors } \\
\text { (after 1752) }\end{array}$ \\
\hline 43:g1 & ...Q-43 & Grundig (A1) & W-Dl-041 (Zohn 1) & Quadri (1730) \\
\hline $43: g 4$ & $\ldots \mathrm{Q}-42$ & Morgenstern (D2) & W-Dl-041 (Zohn 1) & \\
\hline 43:A1 & ...Q-34 & Grundig (A1) & W-Dl-041 (Zohn 1) & Quadri (1730) \\
\hline 43:A6/i-ii & $\ldots \mathrm{N}-6 \mathrm{~b}$ & $\begin{array}{l}\text { Morgenstern (D2) } \\
\text { Pisendel }\end{array}$ & $\begin{array}{l}\text { W-Dl-001 (Zohn 6) IGS } \\
\text { W-Dl-041 (Zohn 1) } \\
\text { W-D-086? (Zohn 21) } \\
\end{array}$ & \\
\hline $43: B 2$ & $\ldots Q-16$ & Morgenstern (D2) & W-Dl-041 (Zohn 1) & \\
\hline
\end{tabular}




\begin{tabular}{|c|c|c|c|c|}
\hline$T W V$ & Mus.2392-... & Copyist(s) & Watermark(s) & Non-Dresden Concordances \\
\hline 43:h1 & $\ldots \mathrm{Q}-40$ & Grundig (A1) & W-Dl-041 (Zohn 1) & Quadri (1730) \\
\hline 44:11 & $\ldots$ Q-14a & Grundig (A3) & W-Dl-001 (Zohn 6) IGS & \\
\hline $50: 5$ & $\ldots \mathrm{N}-16$ & $\begin{array}{l}\text { Grundig (A3), Morgenstern } \\
\text { (D4) }\end{array}$ & W-Dl-001 (Zohn 6) IGS & \\
\hline 51:C2 & $\ldots \mathrm{O}-1$ & Schreiber u & W-Dl-081? (Zohn 6) & D-DS \\
\hline 51:a1 & $\begin{array}{l}\ldots \mathrm{O}-13 \mathrm{a} \\
\ldots \mathrm{O}-13 \mathrm{~b}\end{array}$ & $\begin{array}{l}\text { Schreiber B of Hamburg } \\
\text { Grundig (A1) }\end{array}$ & $\begin{array}{l}\text { W-Dl-056 (Zohn 16) ES } \\
\text { W-Dl-041 (Zohn 1) }\end{array}$ & D-Hs \\
\hline 51:f1 & $\ldots \mathrm{O}-25$ & Grundig (A1) & W-Dl-041 (Zohn 1) & D-DS \\
\hline $51: f 2$ & $\ldots \mathrm{O}-26$ & Grundig (A2) & W-Dl-001 (Zohn 6) IGS & \\
\hline 51:G6a & $\ldots \mathrm{O}-57 \mathrm{a}$ & Pisendel & W-Dl-041 (Zohn 1?) & D-DS \\
\hline 52:Es1 & $\ldots \mathrm{O}-31 \mathrm{~b}$ & Grundig (A1) & W-Dl-042 (Zohn 1) & D-SWl \\
\hline $52: F 2$ & $\ldots \mathrm{O}-24$ & Grundig (A1) & none & \\
\hline $52: G 2 / \mathrm{i}$ & Mus.2199-N-3 & Morgenstern (D4) & W-Dl-001 (Zohn 6) IGS & D-DS, US-Wc \\
\hline 53:D5 & $\ldots \mathrm{O}-61$ & Pisendel, unknown & $\begin{array}{l}\text { W-Dl-086 (Zohn 21) } \\
\text { W-Dl-196 (Zohn 37) }\end{array}$ & D-DS \\
\hline $53: \mathrm{e} 2$ & $\ldots \mathrm{O}-14$ & Grundig (A1) & W-Dl-041 (Zohn 1) & \\
\hline 54:D2 & $\ldots \mathrm{O}-30$ & Pisendel, Morgenstern (D2) & W-Dl-041 (Zohn 1) & D-DS \\
\hline $54: F 1$ & $\begin{array}{l}\ldots \mathrm{O}-59 \\
\ldots \mathrm{O}-60 \\
\end{array}$ & $\begin{array}{l}\text { Pisendel } \\
\text { Grundig (A1) }\end{array}$ & $\begin{array}{l}\text { W-Dl-001 (Zohn 6) IGS } \\
\text { none }\end{array}$ & D-SWl \\
\hline $55: \mathrm{C} 6 / \mathrm{v}$ & Mus.2410-F-14 & Grundig (A1) & W-Dl-041 (Zohn 1) & D-DS \\
\hline $55: C 7$ & $\ldots \mathrm{N}-2$ & Grundig (A1) & W-Dl-041 (Zohn 1) & \\
\hline 55:c2 & $\ldots \mathrm{N}-30$ & Morgenstern (D0) & $\begin{array}{l}\text { W-Dl-041 (Zohn 1) } \\
\text { W-Dl-043 (Zohn 2) } 1728\end{array}$ & D-DS \\
\hline $\begin{array}{l}55: D 15 / \text { vii- } \\
\text { viii }\end{array}$ & Mus.2410-F-26 & $\begin{array}{l}\text { Grundig (A1), Morgenstern } \\
\text { (D2), unknown }\end{array}$ & $\begin{array}{l}\text { W-Dl-041 and } 042 \text { (Zohn } \\
\text { 1) } \\
\text { W-Dl-293 }\end{array}$ & D-DS \\
\hline 55:D20 & $\ldots \mathrm{N}-5$ & $\begin{array}{l}\text { Grundig (A1), Morgenstern } \\
\text { (D2) }\end{array}$ & $\begin{array}{l}\text { W-Dl-041 and } 042 \text { (Zohn } \\
\text { 1) }\end{array}$ & \\
\hline $\begin{array}{l}\text { 55:d3/ii-iii, } \\
\text { v-vi, viii }\end{array}$ & Mus.2410-F-29 & $\begin{array}{l}\text { Grundig (A1), Morgenstern } \\
\text { (D2) }\end{array}$ & $\begin{array}{l}\text { W-Dl-041 and } 042 \text { (Zohn } \\
\text { 1) }\end{array}$ & D-DS \\
\hline 55:Es4/iv & $\begin{array}{l}\text { Mus.2-N-13,11 } \\
\text { (3) }\end{array}$ & $\begin{array}{l}\text { Morgenstern (D2), Grundig } \\
\text { (A2), Pisendel }\end{array}$ & $\begin{array}{l}\text { W-Dl-001 (Zohn 6) IGS } \\
\text { W-Dl-041 (Zohn 1) }\end{array}$ & D-DS, D-ROu, D-SWl \\
\hline 55:E3 & $\ldots \mathrm{O}-7$ & Grundig (A4) & $\begin{array}{l}\text { W-Dl-002 (Zohn 7a) } \\
\text { Dresden J G Schuchart }\end{array}$ & \\
\hline 55:e1 & $\ldots \mathrm{O}-39$ & Grundig (A3) & W-Dl-001 (Zohn 6) IGS & Musique de table (1733) \\
\hline 55:e8 & $\ldots \mathrm{N}-18$ & Grundig (A1) & none & D-DS \\
\hline 55:e9 & $\ldots \mathrm{N}-14$ & Grundig (A1) & W-Dl-042 (Zohn 1) & \\
\hline 55:e10/ii-vi & $\begin{array}{l}\text { Mus.2-N-13,10 } \\
(15-20)\end{array}$ & Grundig (A1), Pisendel & $\begin{array}{l}\text { W-Dl-001 (Zohn 6) IGS } \\
\text { W-Dl-041 and 042 (Zohn } \\
\text { 1) } \\
\text { W-Dl-222 }\end{array}$ & \\
\hline $\begin{array}{l}55: \mathrm{F} 10 / \mathrm{i} \\
55: \mathrm{F} 10 / \mathrm{ii}\end{array}$ & $\begin{array}{l}\ldots \mathrm{N}-5 \\
\text { Mus.2-N-13,10 } \\
(37)\end{array}$ & $\begin{array}{l}\text { Grundig (A1) } \\
\text { Grundig (A1), Pisendel }\end{array}$ & $\begin{array}{l}\text { none } \\
\text { W-Dl-001 (Zohn 6) IGS } \\
\text { W-Dl-041 and } 042 \\
\text { (Zohn 1) } \\
\text { W-Dl-222 }\end{array}$ & D-DS \\
\hline
\end{tabular}




\begin{tabular}{|c|c|c|c|c|}
\hline$T W V$ & Mus.2392-... & Copyist(s) & Watermark(s) & Non-Dresden Concordances \\
\hline 55:F11 & $\ldots \mathrm{N}-32$ & Schreiber B of Hamburg & $\begin{array}{l}\text { W-Dl-053 (Zohn 16) ES } \\
\text { W-Dl-190 (Zohn 30) B }\end{array}$ & D-B, D-DS, D-ROu \\
\hline $55: \mathrm{F} 13$ & $\ldots \mathrm{O}-10 \mathrm{~b}$ & Grundig (A1) & none & \\
\hline 55:G6/iii-v & $\begin{array}{l}\text { Mus.2-N-13,10 } \\
(12-14)\end{array}$ & Grundig (A1), Pisendel & $\begin{array}{l}\text { W-Dl-001 (Zohn 6) IGS } \\
\text { W-Dl-041 and 042 (Zohn } \\
\text { 1) } \\
\text { W-Dl-222 }\end{array}$ & D-DS \\
\hline $\begin{array}{l}55: g 7 \\
55: g 7 / \text { iii-iv }\end{array}$ & $\begin{array}{l}\ldots \mathrm{O}-16 \mathrm{~b} \\
\text { Mus.2-N-13,10 } \\
(41-42)\end{array}$ & $\begin{array}{l}\text { Grundig (A1) } \\
\text { Grundig (A1), Pisendel }\end{array}$ & $\begin{array}{l}\text { W-Dl-042 (Zohn 1) } \\
\text { W-Dl-001 (Zohn 6) IGS } \\
\text { W-Dl-041 and } 042 \text { (Zohn } \\
\text { 1) } \\
\text { W-Dl-222 }\end{array}$ & \\
\hline 55:g8 & $\ldots \mathrm{O}-41$ & Morgenstern (D0) & W-Dl-043 (Zohn 2) 1728 & \\
\hline 55:A8/iii-viii & $\begin{array}{l}\text { Mus.2-N-13,10 } \\
(22-28)\end{array}$ & Grundig (A1), Pisendel & $\begin{array}{l}\text { W-Dl-001 (Zohn 6) IGS } \\
\text { W-Dl-041 and } 042 \text { (Zohn } \\
\text { 1) } \\
\text { W-Dl-222 }\end{array}$ & D-MÜu, D-SWl S-L, S-Skma \\
\hline 55:a3 & $\ldots \mathrm{N}-13$ & Grundig (A1) & none & D-DS \\
\hline $55: \mathrm{B} 7$ & $\ldots \mathrm{O}-33$ & $\begin{array}{l}\text { Grundig (A1), Morgenstern } \\
\text { (D2) }\end{array}$ & W-Dl-041 (Zohn 1) & D-DS \\
\hline 55:B10 & $\ldots \mathrm{N}-11$ & Grundig (A1) & W-Dl-247 & \\
\hline 55:B11 & $\ldots \mathrm{O}-34 \mathrm{a}$ & $\begin{array}{l}\text { Grundig (A1), Morgenstern } \\
\text { (D1 or } 2)\end{array}$ & W-Dl-041 (Zohn 1) & \\
\hline $\begin{array}{l}\text { 55:h4 } \\
55: \mathrm{h} 4 / \text { iii-iv }\end{array}$ & $\begin{array}{l}\text { WO-15 } \\
\text { Mus.2-N-13,11 } \\
(6,8)\end{array}$ & $\begin{array}{l}\text { Schreiber B of Hamburg } \\
\text { Morgenstern (D2), Grundig } \\
\text { (A2), Pisendel }\end{array}$ & $\begin{array}{l}\text { W-Dl-156 (Zohn 17) } \\
\text { W-Dl-001 (Zohn 6) IGS } \\
\text { W-Dl-041 (Zohn 1) }\end{array}$ & \\
\hline
\end{tabular}

\section{Copied c. 1735-1755 (18 works in 23 manuscripts)}

\begin{tabular}{|c|c|c|c|c|}
\hline$T W V$ & Mus.2392-... & Copyist(s) & Watermark(s) & Non-Dresden Concordances \\
\hline 42:c1 & $\ldots \mathrm{Q}-44, \ldots 44 \mathrm{a}$ & Schreiber M & W-Dl-007 (Zohn 7b) GHS & $\begin{array}{l}\text { D-DS, S-Skma; Six Sonates } \\
(1731 / 33)\end{array}$ \\
\hline 42:D4 & $\ldots \mathrm{Q}-32$ & Schreiber M & W-Dl-007 (Zohn 7b) GHS & $\begin{array}{l}\text { D-DS, S-Skma; Six Sonates } \\
(1731 / 33)\end{array}$ \\
\hline $42: \mathrm{d} 2$ & $\ldots Q-41$ & Schreiber M & W-Dl-007 (Zohn 7b) GHS & $\begin{array}{l}\text { D-DS, S-Skma; Six Sonates } \\
(1731 / 33)\end{array}$ \\
\hline $42: \mathrm{e} 1$ & $\ldots \mathrm{Q}-39, \ldots 39 \mathrm{a}$ & Schreiber M & W-Dl-007 (Zohn 7b) GHS & $\begin{array}{l}\text { D-DS, S-Skma; Six Sonates } \\
(1731 / 33)\end{array}$ \\
\hline 42:e12/i, iv & $\ldots \mathrm{N}-15$ & $\begin{array}{l}\text { Morgenstern (D8), } \\
\text { Schreiber T }\end{array}$ & $\begin{array}{l}\text { W-Dl-002 (Zohn 7a) Dresden JG } \\
\text { Schuchart }\end{array}$ & $\mathrm{D}-\mathrm{ROu}$ \\
\hline 42:F11 & $\ldots \mathrm{N}-7$ & Morgenstern (D8) & W-Dl-058 (Zohn 16) ES & \\
\hline $42: G 3$ & $\ldots Q-28$ & S-Dl-136 & $\begin{array}{l}\text { W-Dl-002 (Zohn 7a) Dresden J G } \\
\text { Schuchart }\end{array}$ & $\begin{array}{l}\text { D-DS, S-Skma; Six Sonates } \\
(1731 / 33)\end{array}$ \\
\hline 42:G12 & $\ldots \mathrm{Q}-27, \ldots 27 \mathrm{a}$ & Schreiber M & W-Dl-007 (Zohn 7b) GHS & $\begin{array}{l}\text { Six Sonates } \\
(1731 / 33)\end{array}$ \\
\hline
\end{tabular}




\begin{tabular}{|c|c|c|c|c|}
\hline$T W V$ & Mus.2392-... & Copyist(s) & Watermark(s) & Non-Dresden Concordances \\
\hline 42:g13 & $\begin{array}{l}\cdots \mathrm{Q}-50 \\
\ldots \mathrm{Q}-50 \mathrm{~b}\end{array}$ & $\begin{array}{l}\text { S-Dl-136 } \\
\text { Morgenstern (D8) }\end{array}$ & $\begin{array}{l}\text { W-Dl-104 A (Zohn 7b) } \\
\text { W-Dl-002 (Zohn 7a) Dresden J G } \\
\text { Schuchart }\end{array}$ & $\mathrm{D}-\mathrm{B}$ \\
\hline 42:g14 & ...Q-81 & Schreiber M & W-Dl-007 (Zohn 7b) GHS & \\
\hline 42:A2 & $\ldots Q-33$ & Schreiber M & W-Dl-007 (Zohn 7b) GHS & $\begin{array}{l}\text { D-DS, S-Skma; Six Sonates } \\
(1731 / 33)\end{array}$ \\
\hline 42:A11/ii & $\ldots \mathrm{N}-7$ & Morgenstern (D8) & W-Dl-058 (Zohn 16) ES & D-DS \\
\hline 42:A12 & $\ldots \mathrm{N}-7$ & Morgenstern (D8) & W-Dl-058 (Zohn 16) ES & \\
\hline 51:F4 & $\ldots \mathrm{O}-9$ & Telemann & (Zohn 3) & \\
\hline 55:D19 & $\begin{array}{l}\ldots \mathrm{N}-4 \\
\ldots \mathrm{N}-4 \mathrm{a}\end{array}$ & $\begin{array}{l}\text { S-Dl-053 (Württem- } \\
\text { berg?) } \\
\text { Morgenstern (D8) }\end{array}$ & $\begin{array}{l}\text { W-Dl-150 (Zohn 8) ILB } \\
\text { none }\end{array}$ & \\
\hline 55:F12 & $\begin{array}{l}\ldots \mathrm{N}-8 \\
\ldots \mathrm{N}-8 \mathrm{a}\end{array}$ & $\begin{array}{l}\text { S-Dl-053 (Württem- } \\
\text { berg?) } \\
\text { Morgenstern (D8) }\end{array}$ & $\begin{array}{l}\text { W-Dl-150 (Zohn } 8) I L B \\
\text { none }\end{array}$ & \\
\hline 55:A7 & $\ldots \mathrm{O}-6$ & $\begin{array}{l}\text { S-Dl-053 (Württem- } \\
\text { berg?) }\end{array}$ & W-Dl-150 (Zohn 8) ILB & dated "1741" \\
\hline 55:a6 & $\ldots \mathrm{N}-31$ & Schreiber a & $\begin{array}{l}\text { W-Dl-002 (Zohn 7a) Dresden JG } \\
\text { Schuchart }\end{array}$ & D-SWl \\
\hline
\end{tabular}

\section{Copied at an indeterminate time (5 works in 5 manuscripts)}

\begin{tabular}{|l|l|l|l|l|}
\hline$T W V$ & Mus.2392-... & Copyist(s) & Watermark(s) & Non-Dresden Concordances \\
\hline $\begin{array}{l}41: \mathrm{g} 9 / \\
\text { g11 }\end{array}$ & $\ldots$ R-1 & unknown & $?$ & D-B \\
\hline 42:g13 & $\ldots$ Q-50a & S-Dl-097 & W-Dl-104 (Zohn 31) A & D-B \\
\hline 51:c1 & ..Q-52 & S-Dl-114 (Eisenach?) & W-Dl-186 (Zohn 28) & D-DS \\
\hline 51:g1 & ..O-17b & S-Dl-055 & none & D-DS, BWV 985 \\
\hline 53:E1 & $\ldots$ O-32 & S-Dl-026 and 033 (Darmstadt?) & $\begin{array}{l}\text { W-Dl-195 (Zohn 35) IDB } \\
\text { W-Dl-313 }\end{array}$ & D-DS \\
\hline
\end{tabular}


Table 2. Dresden Manuscripts in the Hand of Johann Gottlieb Morgenstern /Schreiber P

Sources for copyists include Fechner, Studien 1999 (as footnote 1): Schreiber P(1) and P(2); and Landmann, Drei Studien 2010 (as footnote 2): Morgenstern Schriftform a (“um 1718?"), Schriftform b ("Lindner-Typus" / "Schreiber P", "um 1721", "um 1723?”, "vor 1725”), and Schriftform c (“eine Zwischenform”, “1723”). Watermark numbers beginning "W-Dl” are those assigned by the research project "Die Instrumentalmusik der Dresdner Hofkapelle zur Zeit der sächsisch-polnischen Union. Erschließung, Digitalisierung und Internetpräsentation". Watermark numbers in parentheses derive from Zohn, Paper 2000 (as footnote 1), and are designated Zohn ... Letters, words or digits featured in the watermarks are added in italics.

\begin{tabular}{|c|c|c|c|c|}
\hline Shelfmark & Work & Copyist & Watermark & Comments \\
\hline Mus.2154-N-1,1 & J. C. Schmidt, Ouverture & $\begin{array}{l}\text { Morgenstern b } \\
{[\mathrm{P} 2 ?]}\end{array}$ & $\begin{array}{l}\text { W-Dl-082 (Zohn } \\
\text { 9) } \mathrm{HB}\end{array}$ & $\begin{array}{l}\text { "Basso" part only; other parts by } \\
\text { Lindner on same paper }\end{array}$ \\
\hline Mus.2154-N-3 & J.C. Schmidt, Partie & Morgenstern $b$ & $\begin{array}{l}\text { W-Dl-082 (Zohn } \\
\text { 9) } \mathrm{HB}\end{array}$ & $\begin{array}{l}\text { "Basso ô Cembalo } 2^{\mathrm{do} "} \text { part only; } \\
\text { other parts by J. W. Schmidt on } \\
\text { same paper }\end{array}$ \\
\hline Mus.2358-N-9a & Zelenka, ZWV 189 & Morgenstern c & W-Dl-096 OTL? & all parts; copied Prague, $1723 ?$ \\
\hline Mus.2389-O-70a & Vivaldi, RV 314 & Morgenstern a & $?$ & $\begin{array}{l}5 \text { of } 8 \text { parts; title page with mono- } \\
\text { gram "J. G. M." }\end{array}$ \\
\hline Mus.2-N-20, 8 & TWV 55:G6/iii & $\mathrm{P} 2$ & none & $\begin{array}{l}\text { "Violino Primo", "Violino Secondo", } \\
\text { and "Basso" doublets only; other } \\
\text { parts by Pisendel }\end{array}$ \\
\hline Mus.2392-N-3 & TWV 55:G2 & $\mathrm{P} 2$ & $\begin{array}{l}\text { W-Dl-081 (Zohn } \\
10)\end{array}$ & all parts (rev. Pisendel) \\
\hline Mus.2392-O-11 & TWV 51:F2 & $\mathrm{P} 1$ & $\begin{array}{l}\text { W-Dl-256 [not } \\
\text { identifiable] }\end{array}$ & $\begin{array}{l}\text { "Violini Unisoni" }(2 \mathrm{x}) \text {, "Violetta", } \\
\text { "Viola", "Cembalo" }(2 \mathrm{x})=\text { dou- } \\
\text { blets to Pisendel parts (W-Dl-082 } \\
(\text { Zohn 9) } H B) \text {; rev. Pisendel }\end{array}$ \\
\hline Mus.2392-O-19 & TWV 52:B1 & $\begin{array}{l}\text { Morgenstern b } \\
/ \mathrm{P} 2\end{array}$ & none & $\begin{array}{l}\text { all parts (rev. and partly copied by } \\
\text { Pisendel) except "Basso in ripieno" } \\
\text { (Pisendel) }\end{array}$ \\
\hline Mus.2392-O-23 & TWV 55:e10 & $\mathrm{P} 2$ & $\begin{array}{l}\text { W-Dl-081 (Zohn } \\
10)\end{array}$ & all parts (rev. Pisendel) \\
\hline Mus.2392-O-27 & TWV 52:D2 & $\mathrm{P} 2$ & none & all parts (rev. Pisendel) \\
\hline Mus.2392-O-29 & TWV 54:B2 & $\mathrm{P} 2$ & none & all parts (rev. Pisendel) \\
\hline Mus.2392-O-31a & TWV 52:Es1 & $\begin{array}{l}\text { Morgenstern b } \\
\text { / P2 }\end{array}$ & $\begin{array}{l}\text { W-Dl-081 (Zohn } \\
10)\end{array}$ & $\begin{array}{l}\text { all parts (rev. Pisendel); later dou- } \\
\text { blets by Grundig }\end{array}$ \\
\hline Mus.2392-O-32 & TWV 53:E1 & Morgenstern b & $\begin{array}{l}\text { W-Dl-195 (Zohn } \\
\text { 35) IDB } \\
\text { W-Dl-313 }\end{array}$ & $\begin{array}{l}\text { "Buchstaben- und Notenschrift sehr } \\
\text { uneinheitlich" }\end{array}$ \\
\hline Mus.2392-O-36 & TWV 52:G1 & $\mathrm{P} 1$ & none & all parts (rev. Pisendel) \\
\hline Mus.2392-O-58 & TWV 51:B1 & $\begin{array}{l}\text { Morgenstern b } \\
\text { / P1 }\end{array}$ & $\begin{array}{l}\text { W-Dl-019 (Zohn } \\
\text { 5a) }\end{array}$ & $\begin{array}{l}\text { "Violino Primo", "Violino 2do", "Vi- } \\
\text { ola" (each } 2 \mathrm{x}) \text {, "Cembalo" }(3 \mathrm{x})= \\
\text { doublets to Pisendel parts (W-Dl- } \\
021(\text { Zohn } 5 \mathrm{~b}) \text { ), September } 1719 \text { or } \\
\text { later; rev. Pisendel }\end{array}$ \\
\hline
\end{tabular}




\begin{tabular}{|c|c|c|c|c|}
\hline Shelfmark & Work & Copyist & Watermark & Comments \\
\hline Mus.2392-Q-29 & TWV 43:D6 & $\mathrm{P} 2$ & $\begin{array}{l}\text { W-Dl-081 (Zohn } \\
\text { 10) }\end{array}$ & all parts \\
\hline Mus.2392-Q-49 & TWV 42:g12 & $\mathrm{P} 2$ & none & all parts \\
\hline Mus.2392-Q-57 & TWV 42:g15 & $\mathrm{P} 2$ & $\begin{array}{l}\text { W-Dl-081 (Zohn } \\
\text { 10) }\end{array}$ & all parts \\
\hline Mus.2410-Q-25,1 & Händel, HWV 392 & $\begin{array}{l}\text { Morgenstern b/ } \\
{[\mathrm{P} 2 \text {; not } \mathrm{P} 1 \text {, as per }} \\
\text { Fechner }]\end{array}$ & none & $\begin{array}{l}\text { all parts (rev. and partly copied by } \\
\text { Pisendel) }\end{array}$ \\
\hline Mus.2450-O-1,1 & Stölzel, Concerto & $\mathrm{P} 2$ & none & all parts \\
\hline Mus.2468-O-2 & Cattaneo, Concerto & $\begin{array}{l}\text { Morgenstern b } \\
/[\mathrm{P} 1]\end{array}$ & none & $\begin{array}{l}\text { "Violino } 2^{\text {do", "Violetta", "Basso in }} \\
\text { R[ipieno]" parts only (rev. Pisend- } \\
\text { el); other parts by Pisendel (W-Dl- } \\
081(\text { Zohn } 10) \text { ) }\end{array}$ \\
\hline
\end{tabular}




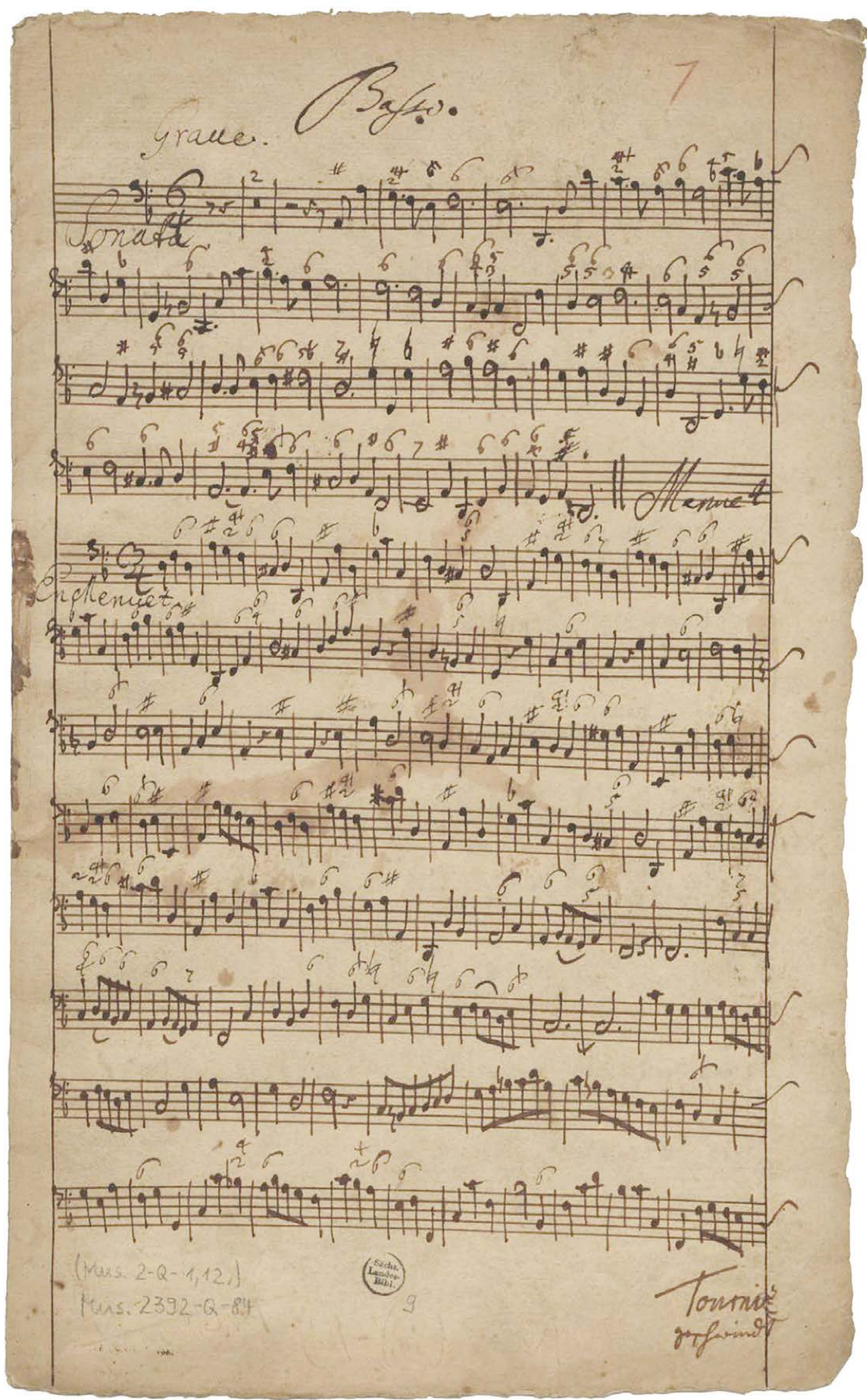

Illustration 1: Telemann, TWV 42:d11, Mus.2392-Q-84, http://digital.slub-dresden.de/id32105220X, Image 13 ("Basso"). Music copied by an unknown scribe, text and continuo figures partially by Pisendel. 

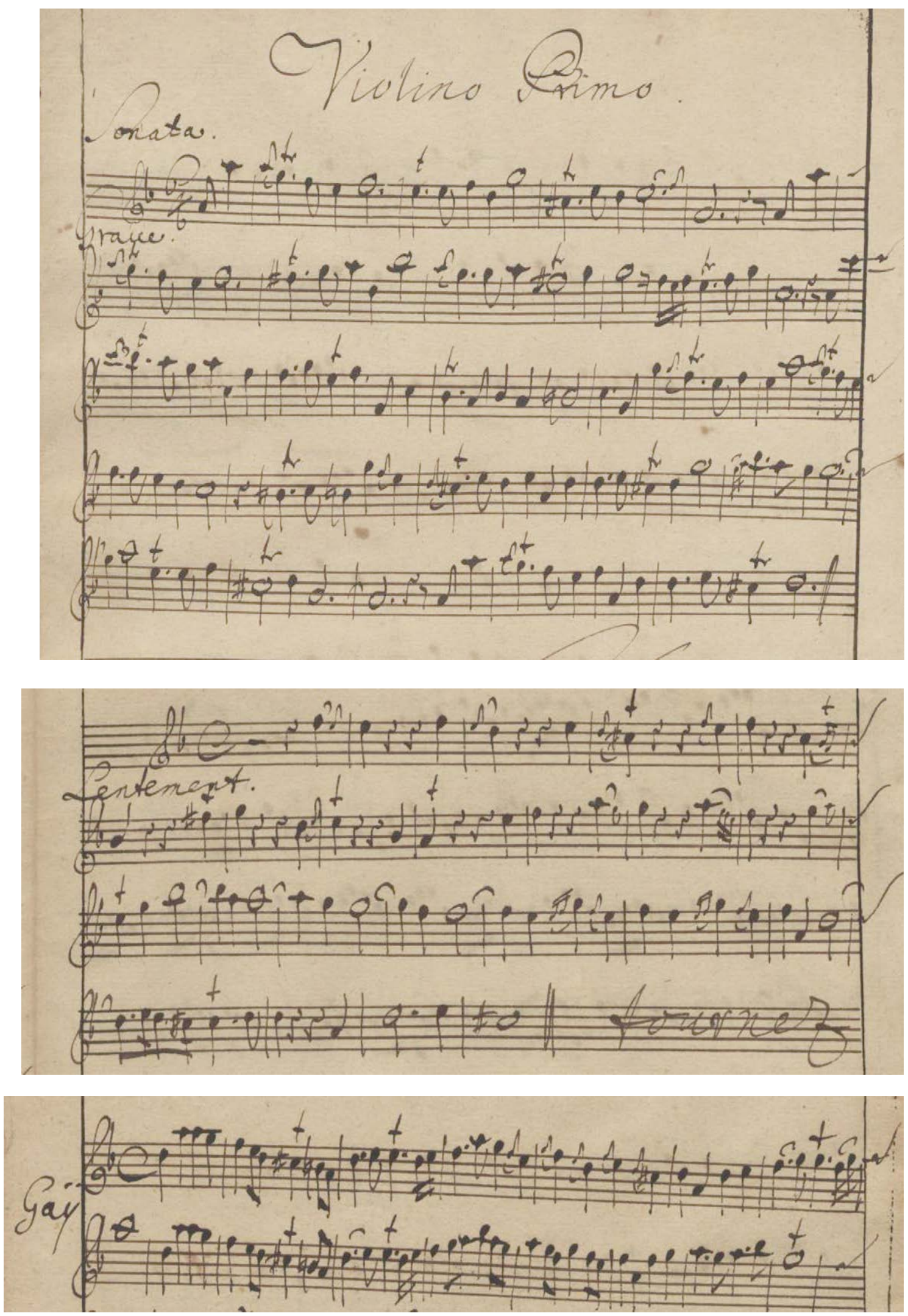

Illustrations 2a-c: Ornamentation in Telemann, TWV 42:d11/i, iii and iv, Mus.2392-Q-84, http://digital. slub-dresden.de/id32105220X, Images 5, 7 and 8 ("Violino Primo": Pisendel). 


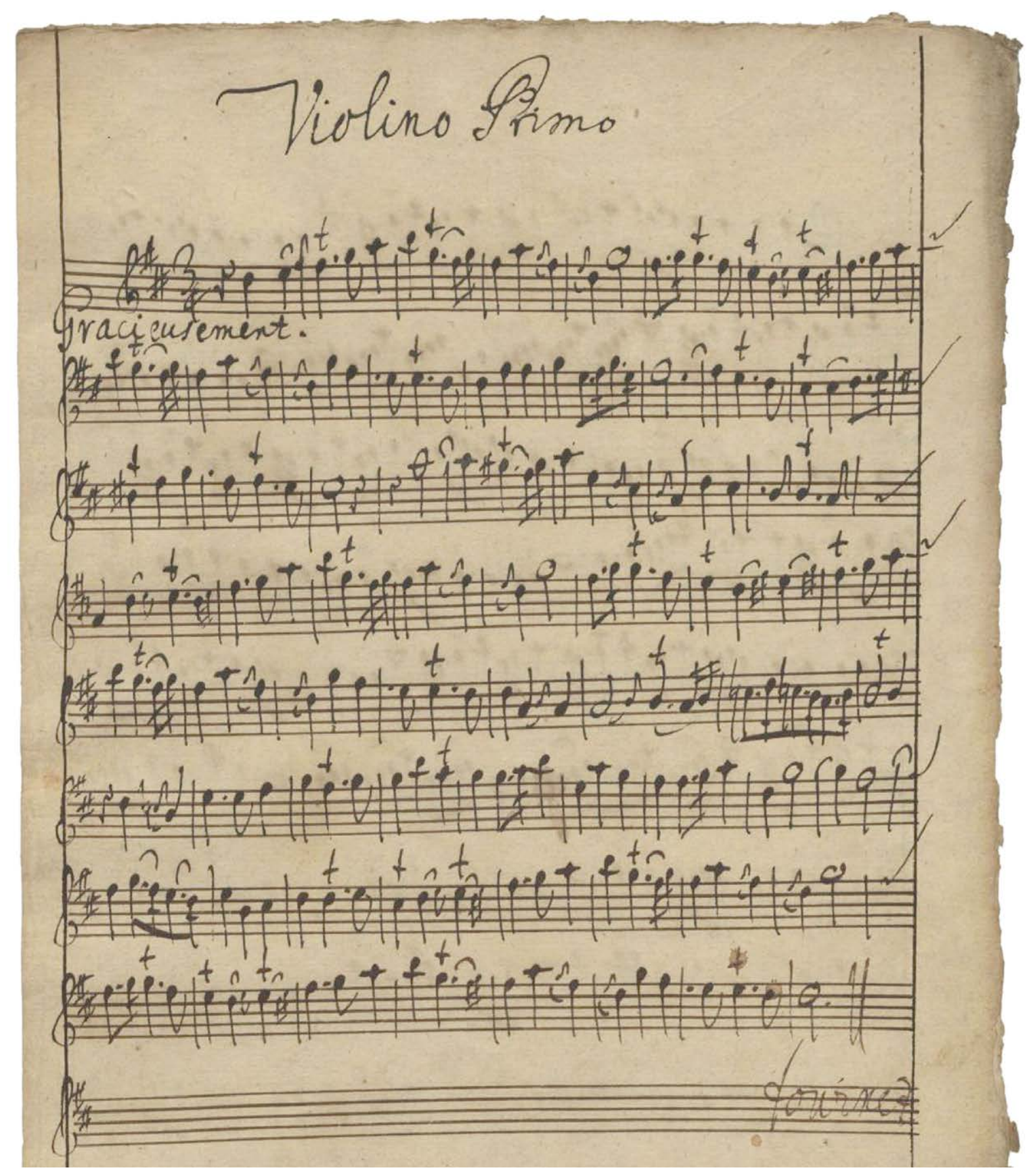

Illustration 3: Ornamentation in Telemann, TWV 42:D16/i, Mus.2392-Q-85a, http://digital.slub-dresden.de/ id321053494, Image 5 ("Violino Primo": Pisendel). 
Entractes Tiohino Srimo conc:

J.

A.

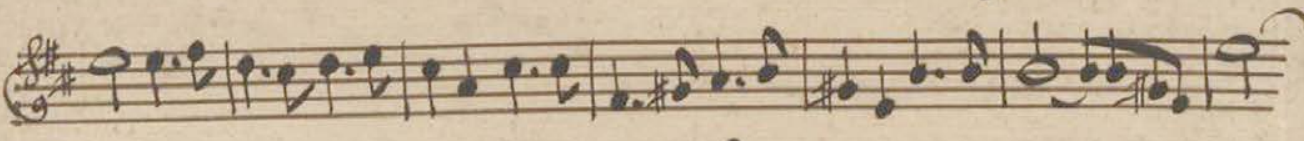

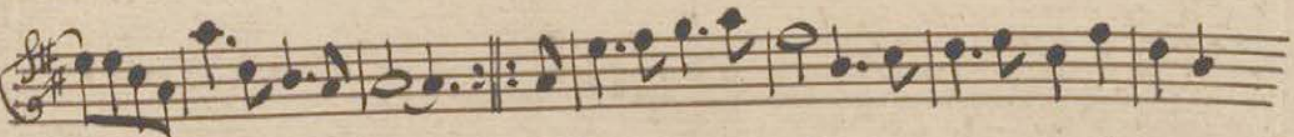

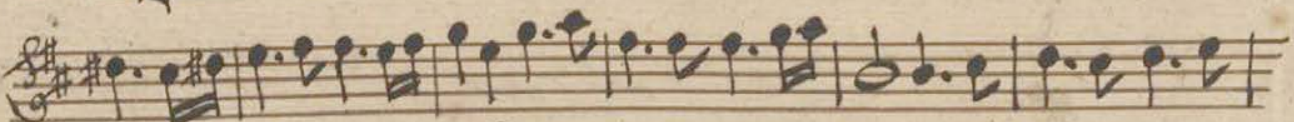

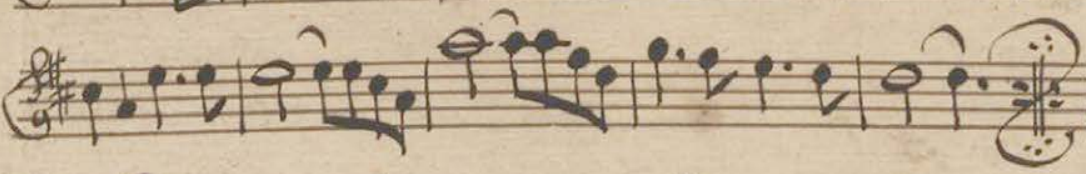

यी

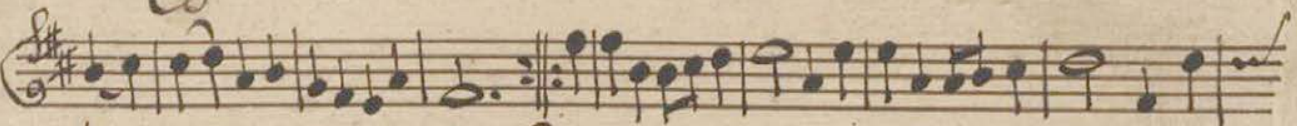
Hoำ

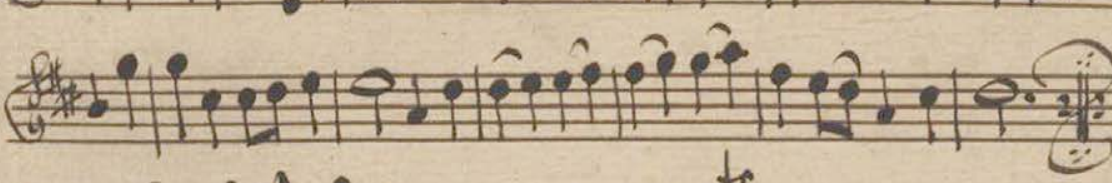
ร. (1n

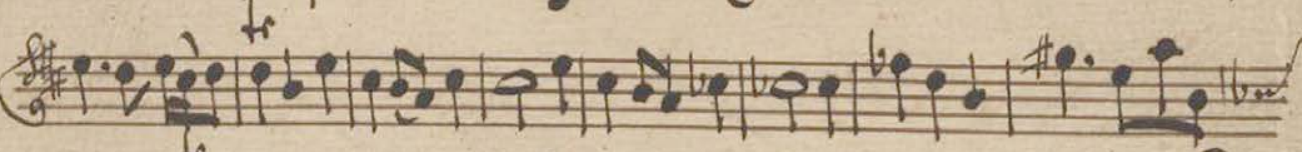

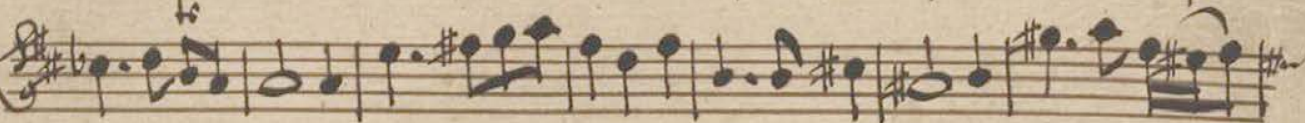

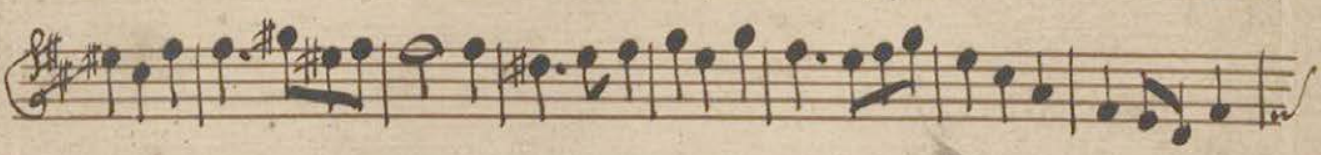

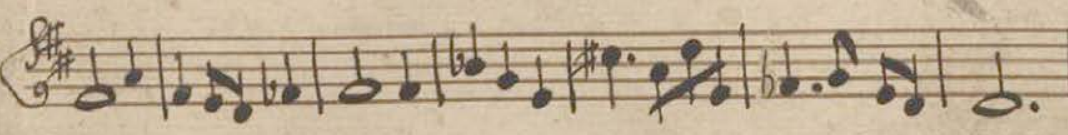

Yoltate

Illustration 4: Telemann, Overture-Suite in D major? (TWV deest), Mus.2-N-13,10 (Zohn 1-3), http://digital. slub-dresden.de/id322161835, Image 9 ("Violino Primo Conc:": Grundig [A1]), "Entrée”, "Rigaudon", and "Air". 
anttaubl:e2 2 Bayfon.

Tivhinoconc:

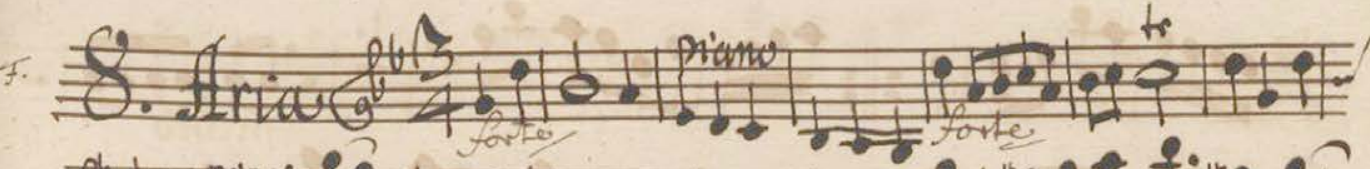

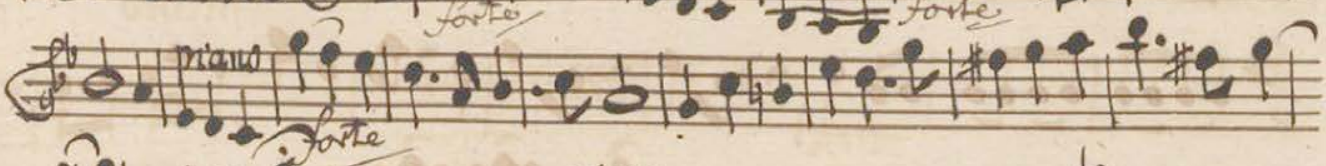

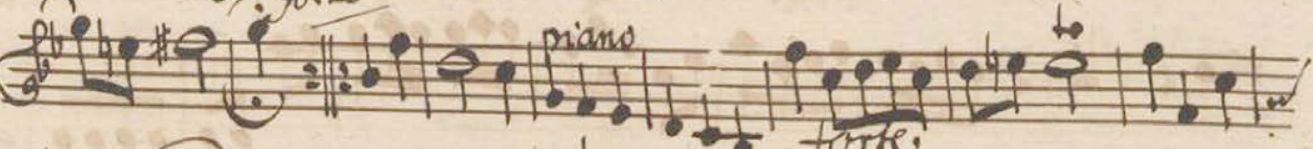
b मिका to torte

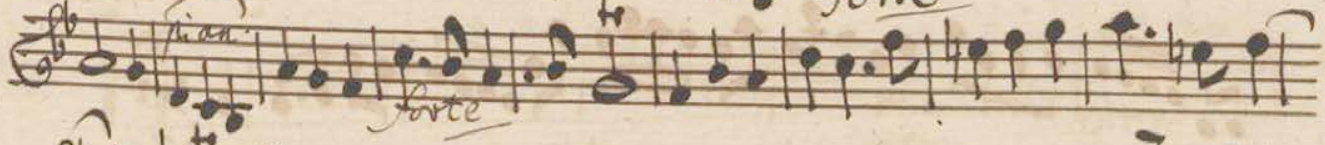

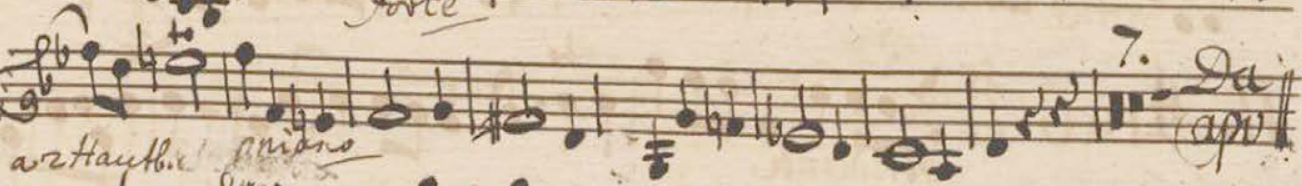

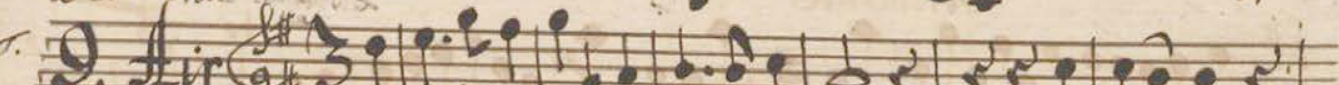
Q. सris Zentement

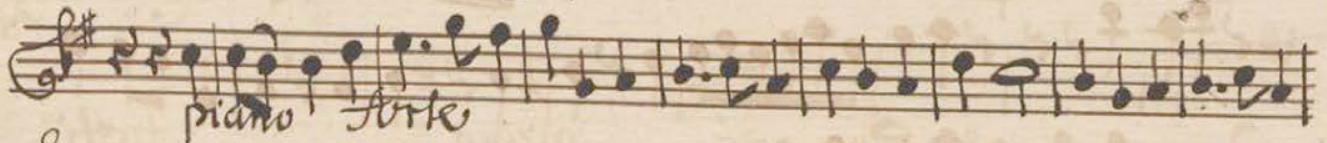

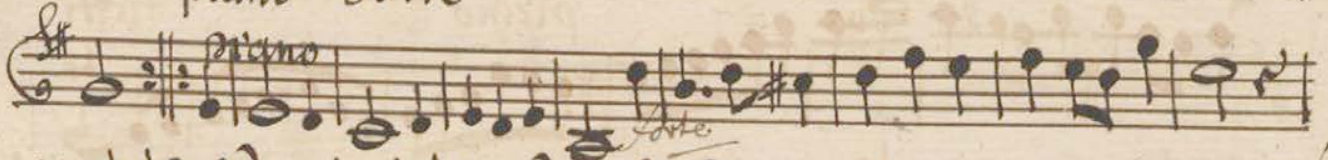

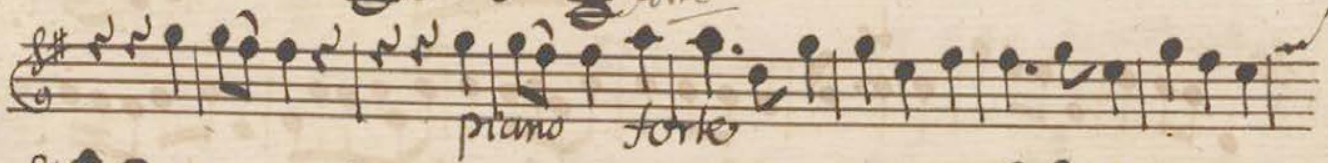
सं

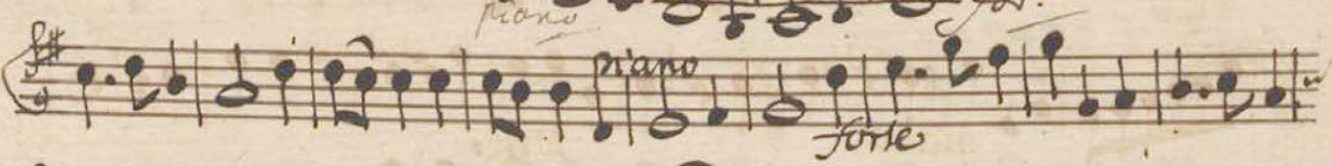

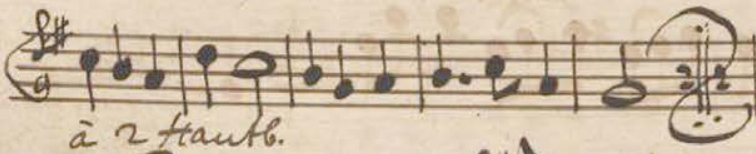

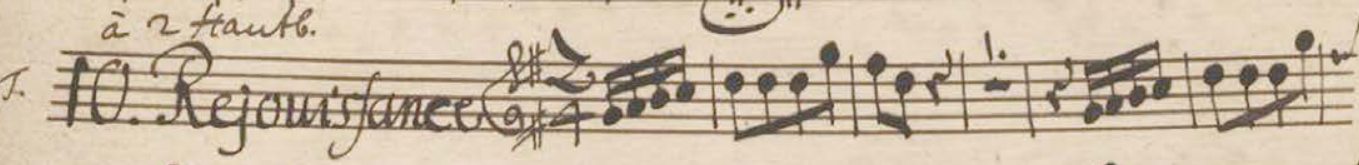

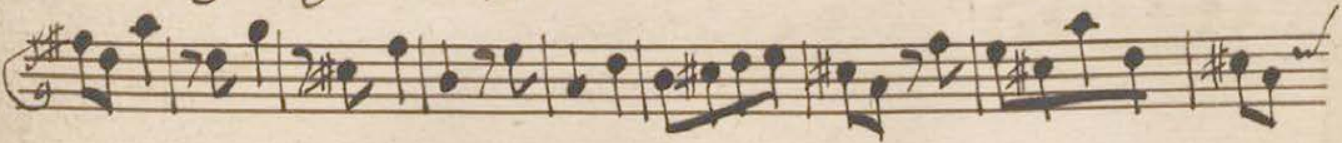

Illustration 5: Telemann, Overture-Suite in G major? (TWV deest), Mus.2-N-13,10 (Zohn 9, 10), http://digital. slub-dresden.de/id322161835, Image 12 ("Violino Primo Conc:": Grundig [A1]), “Air" and "Rejouissance". 


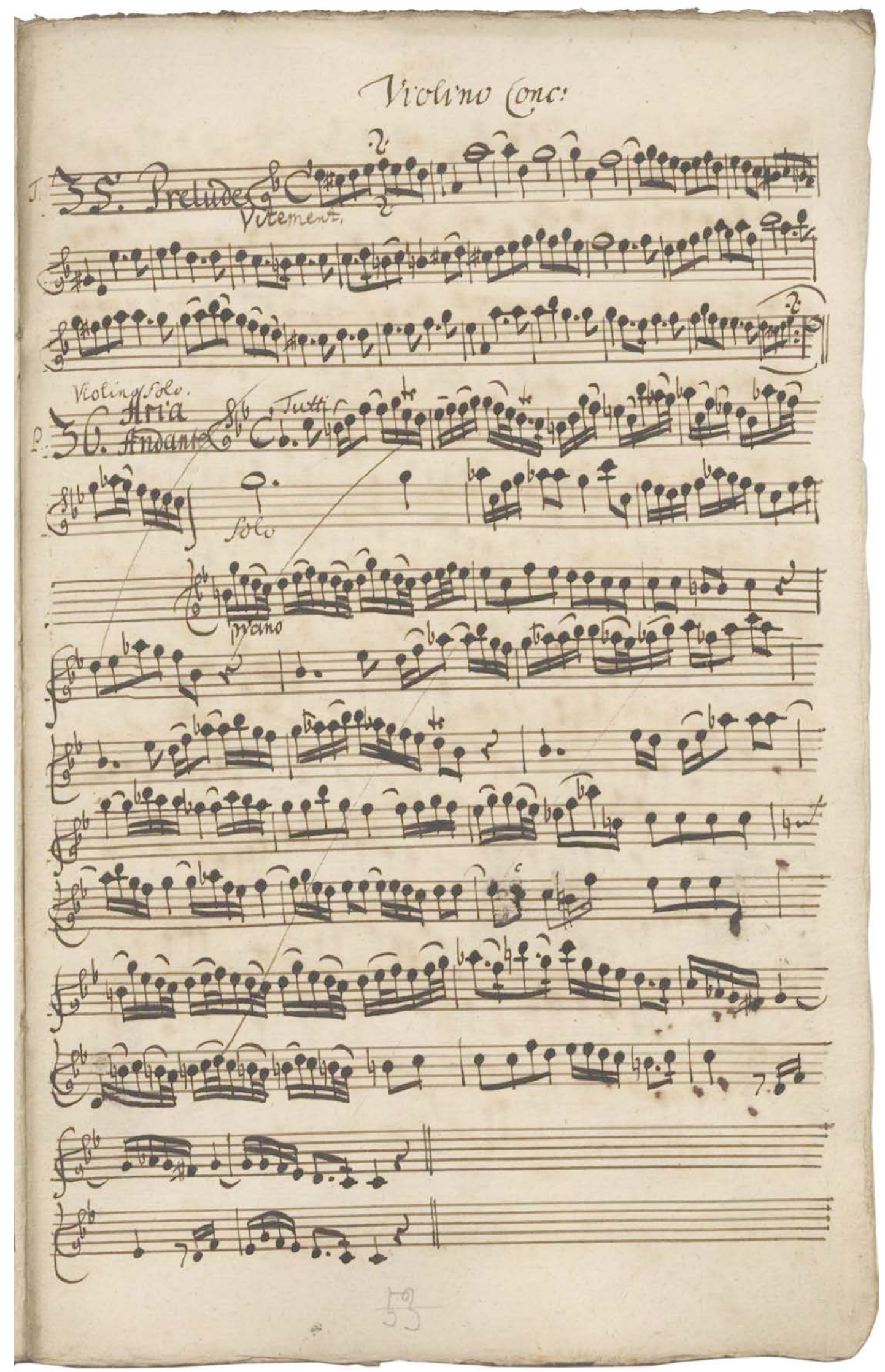

Illustration 6: Telemann, Overture-Suite in D minor? (TWV deest), Mus.2-N-13,10 (Zohn 35), http://digital.slub-dresden.de/id322161835, Image 29 ("Violino Primo Conc:": Grundig [A1]), "Prelude. Vitement”. 


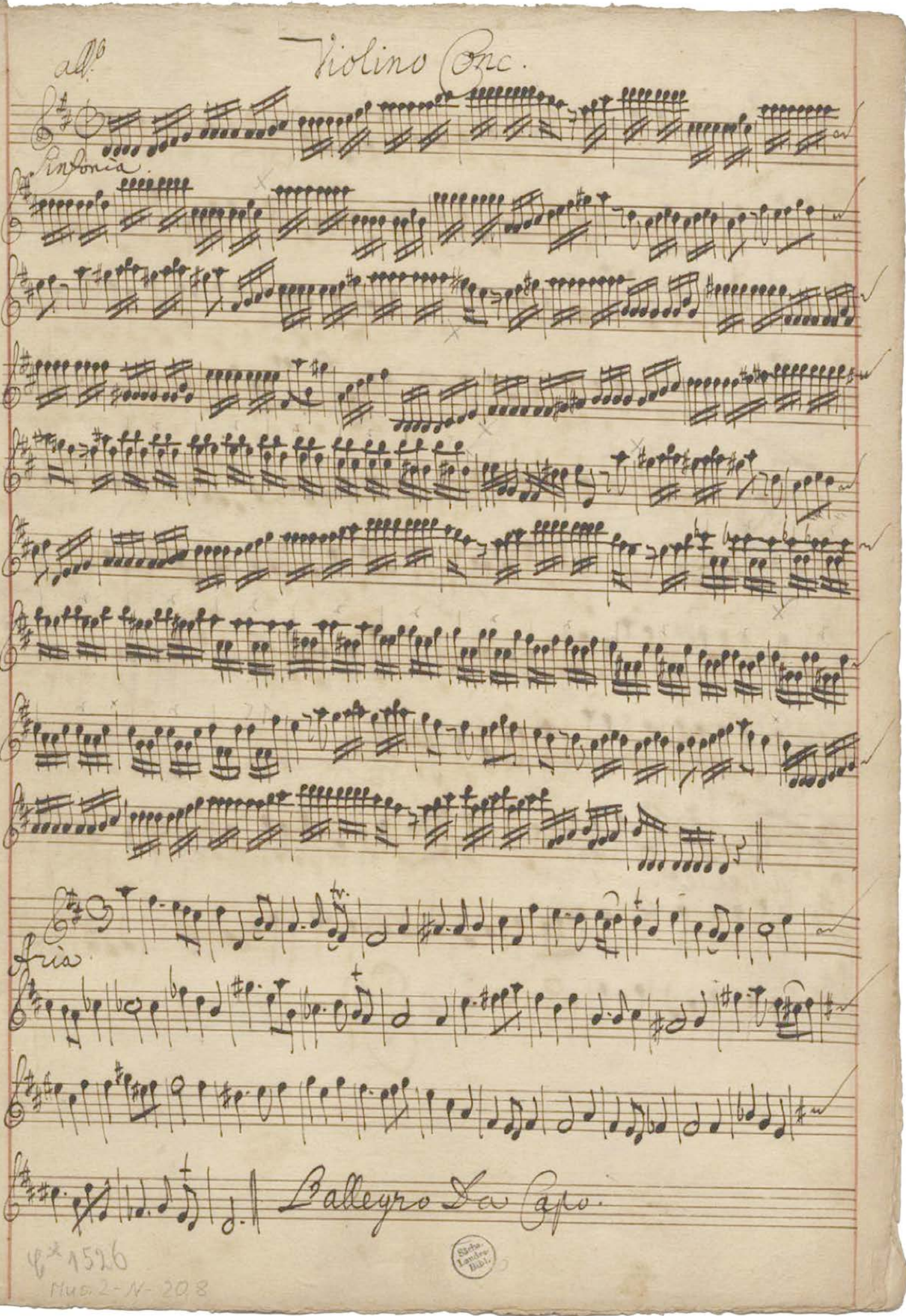

Illustration 7: Telemann, Overture-Suite in D major? (TWV deest), Mus.2-N-20,8,

http://digital.slub-dresden.de/id333079450, Image 5 ("Violino Conc.": Pisendel), "Sinfonia. Allegro" and "Aria". 


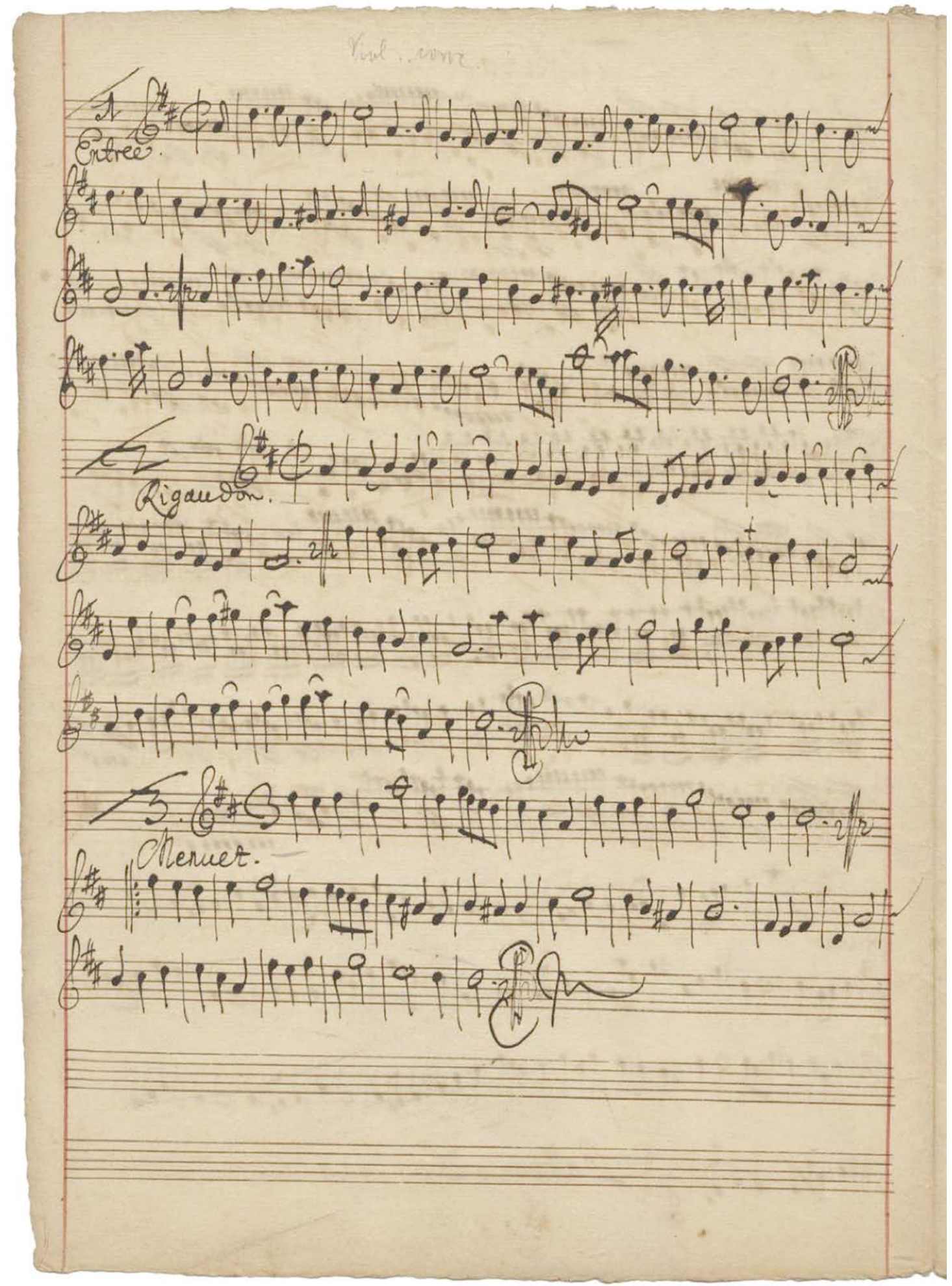

Illustration 8: Telemann, Overture-Suite in D major? (TWV deest), Mus.2-N-20,8,

http://digital.slub-dresden.de/id333079450, Image 6 (“Violino Conc.”: Pisendel), “Entrée”,

"Rigaudon", and "Menuet". 


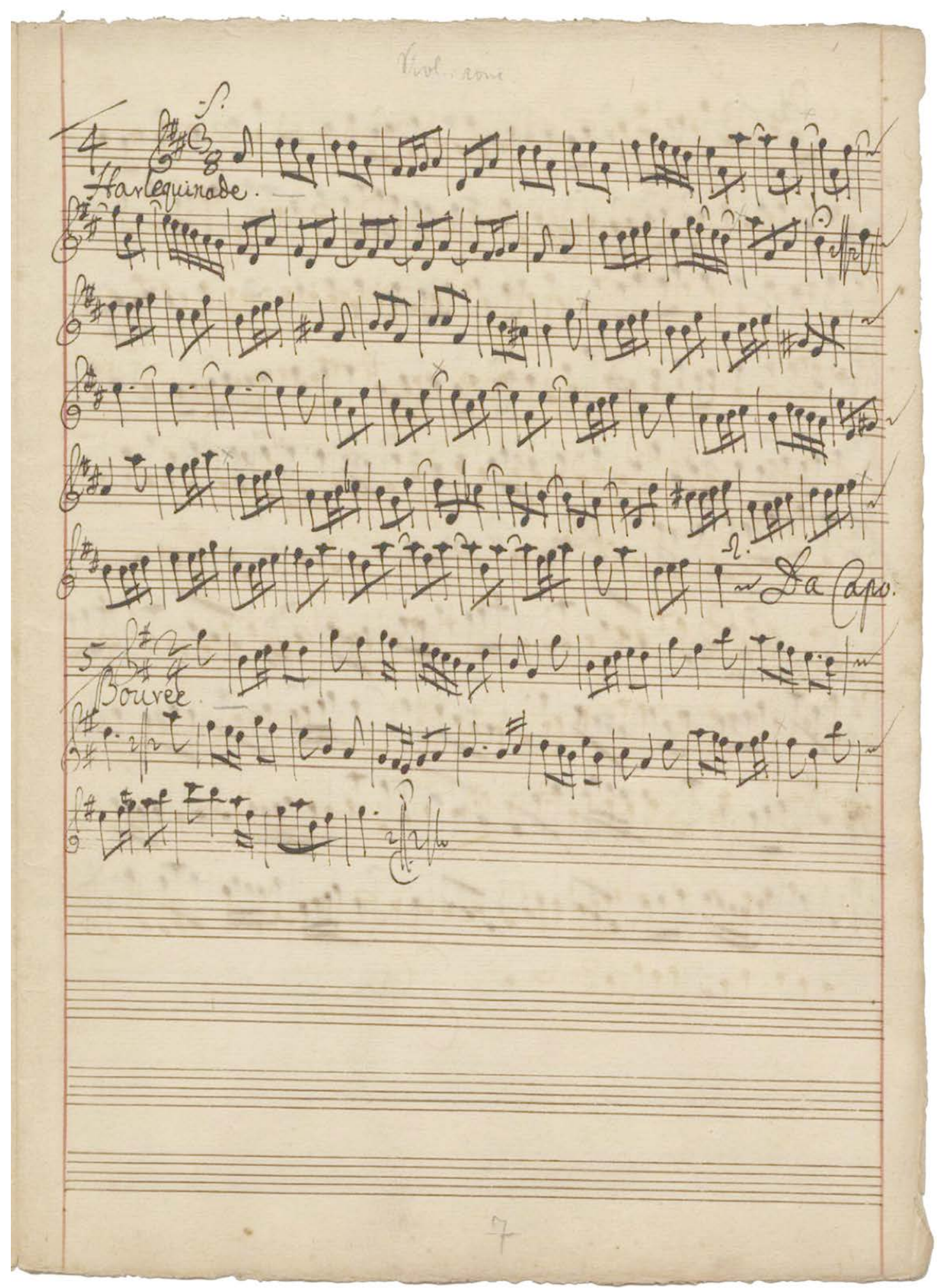

Illustration 9: Telemann, Overture-Suite in D major? (TWV deest) and Overture-Suite in G major, TWV 55:G6, Mus.2-N-20,8, http://digital.slub-dresden.de/id333079450, Image 7 ("Violino Conc.": Pisendel), "Harlequinade" and "Bour[r]ée". 


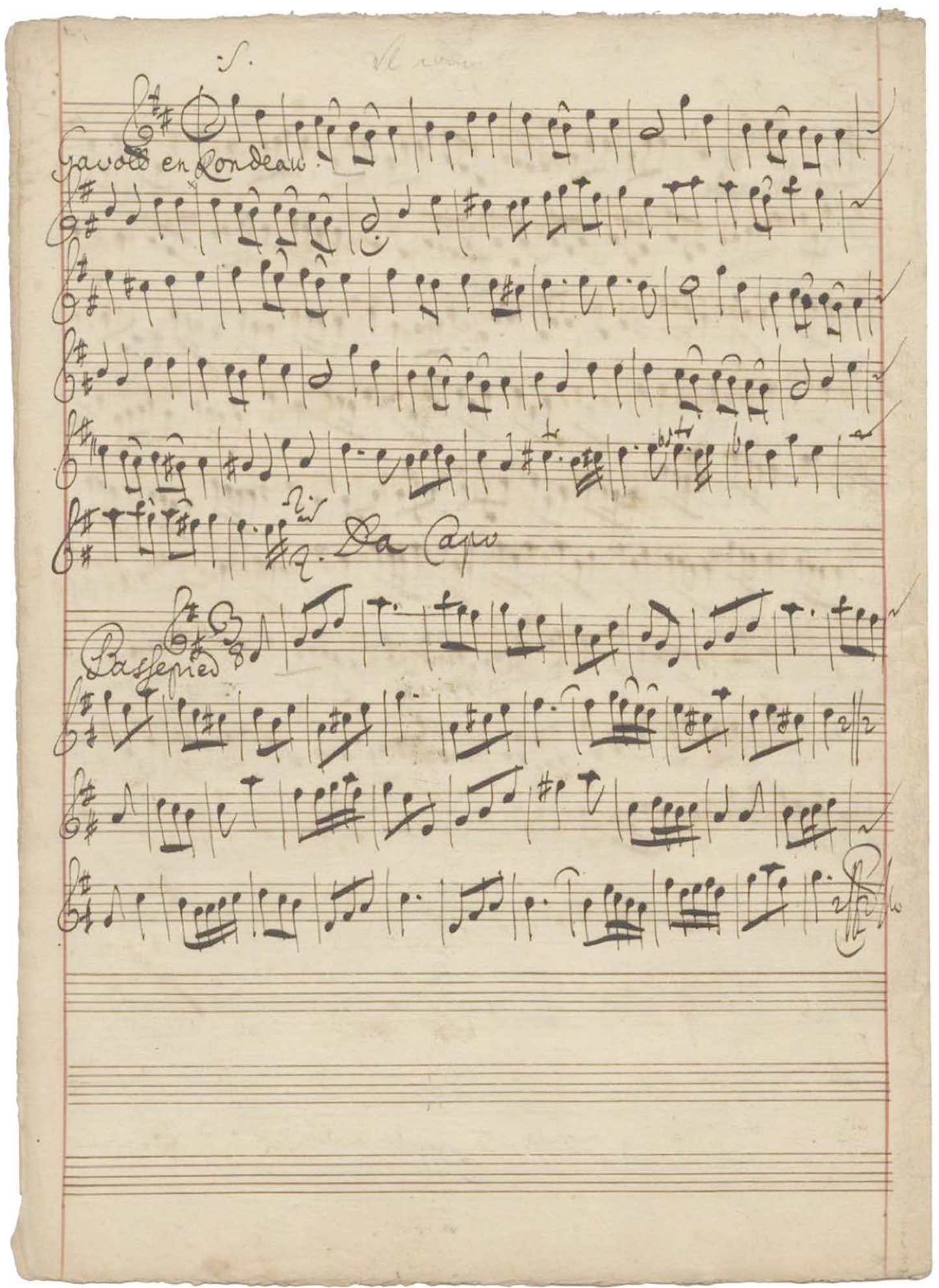

Illustration 10: Telemann, Overture-Suite in G major? (TWV deest), Mus.2-N-20,8, http://digital. slub-dresden.de/id333079450, Image 8 ("Violino Conc.": Pisendel), "Gavotte en Rondeau" and "Passepied". 


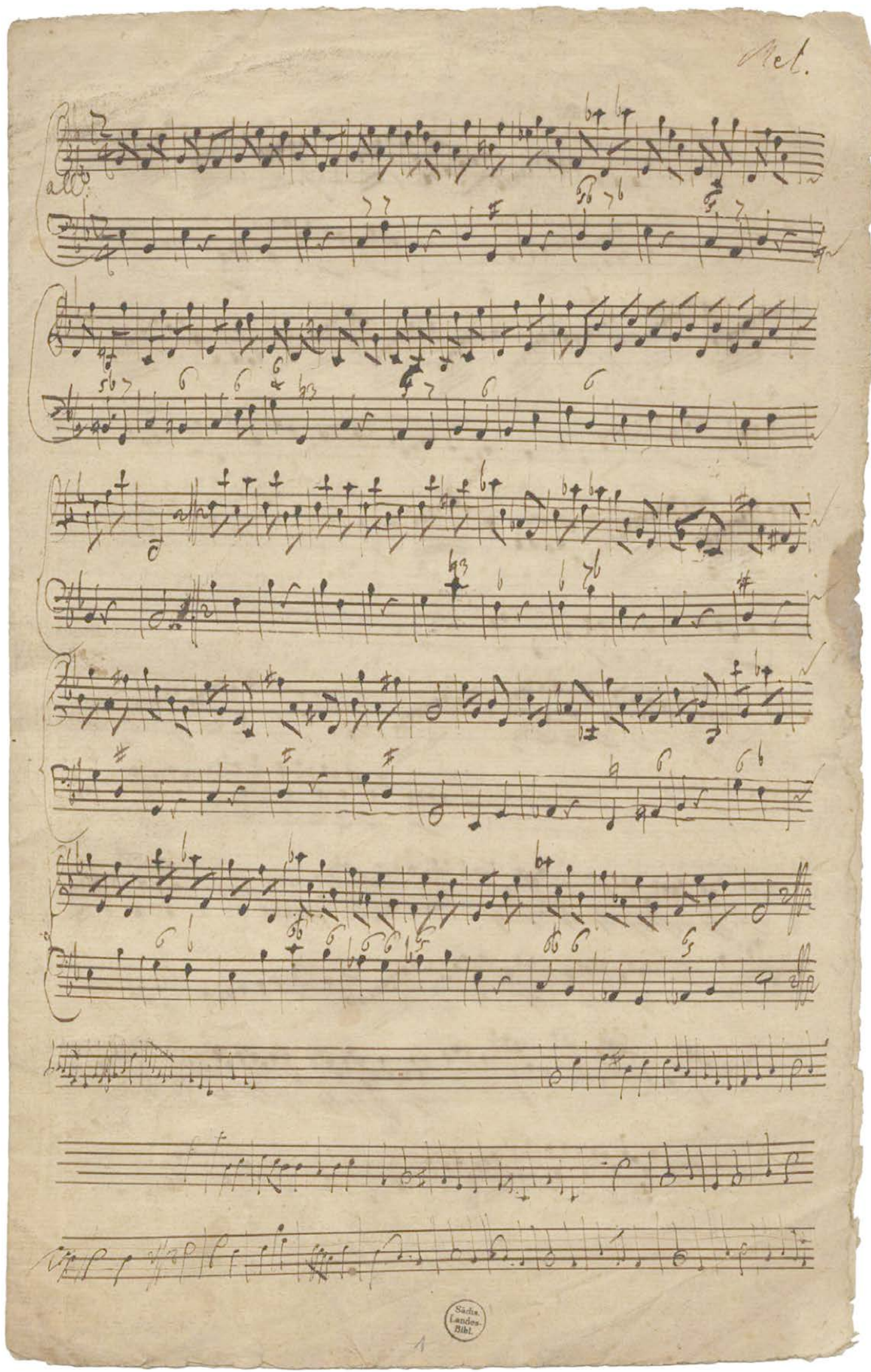

Illustration 11: Telemann, Sonata in E-flat major for violin and continuo? (TWV deest), Mus.2-R-8,85, http://digital.slub-dresden.de/id333024397, Image 5 ([Violino Solo]: Pisendel), "Allegro". 


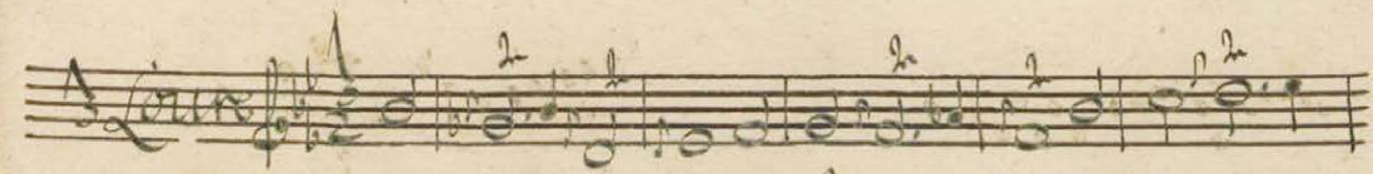

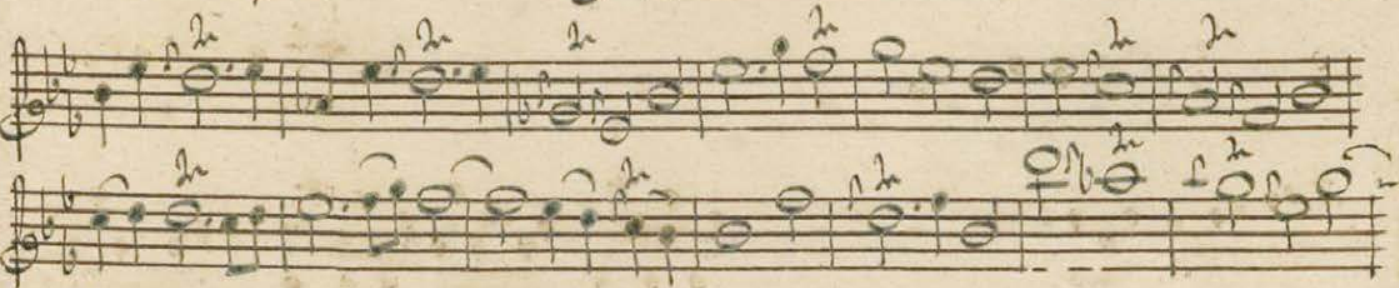

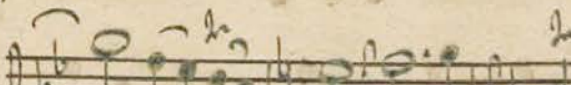

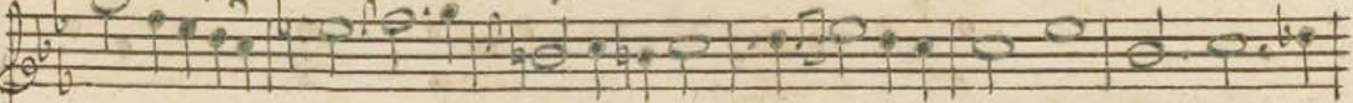

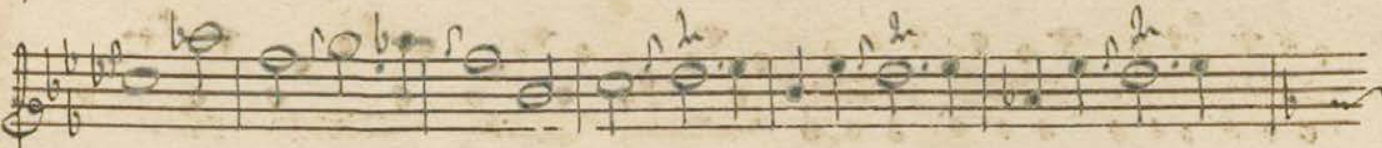

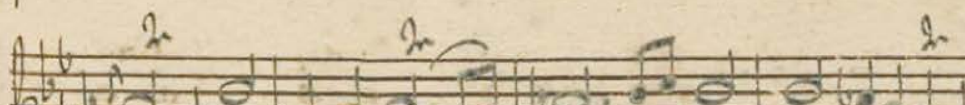

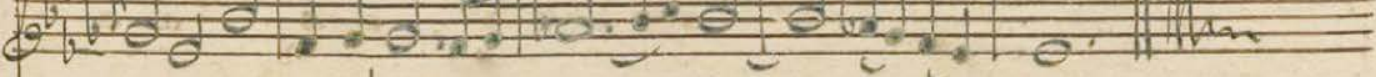
Violinoconi: Si, 1 :
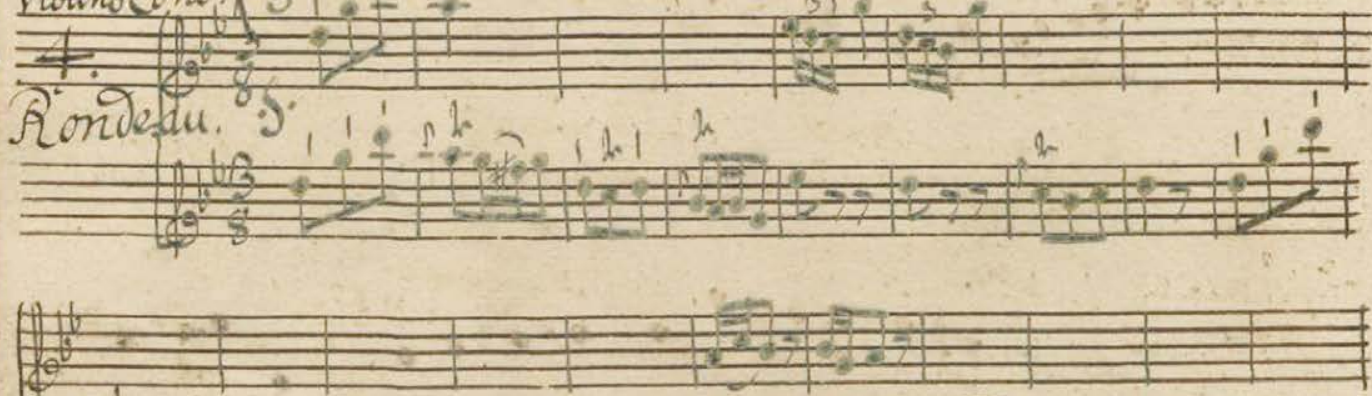

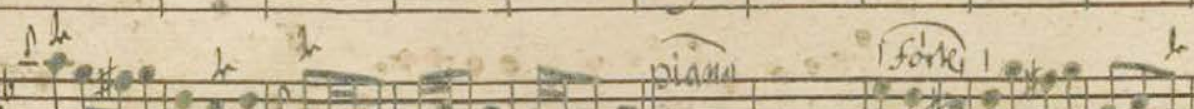

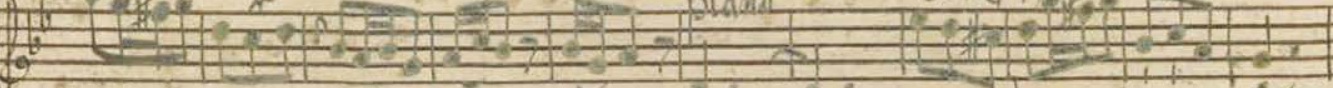

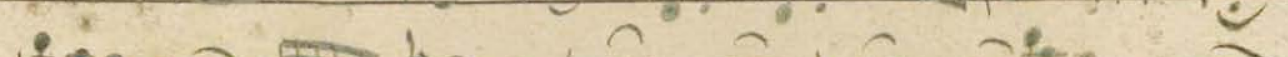

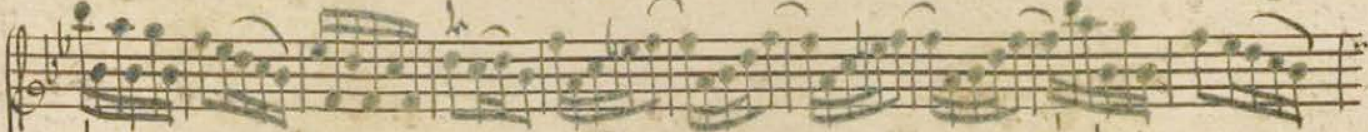

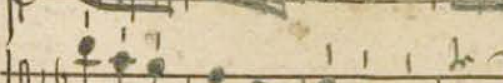
1

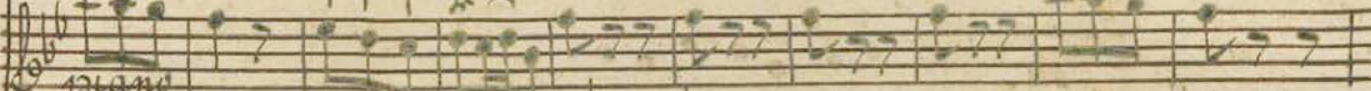

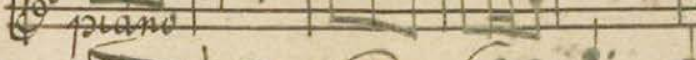

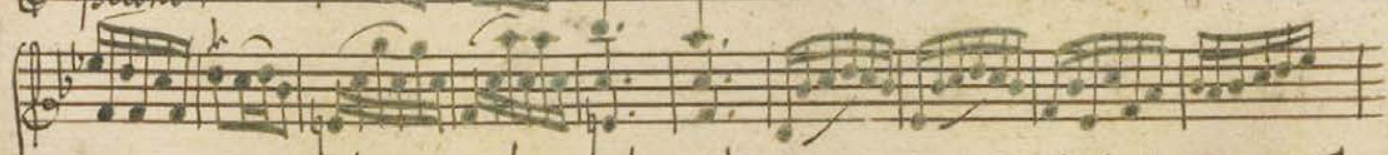

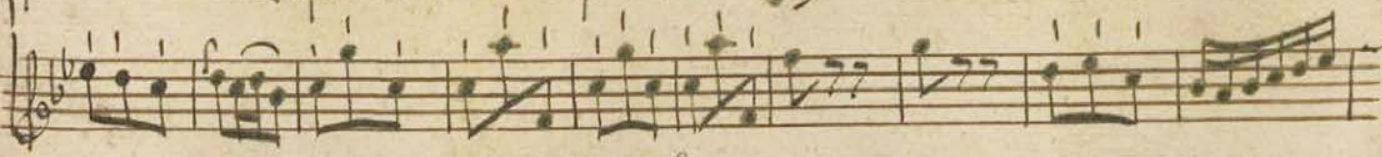

Illustration 12: Ornamentation to Telemann, TWV 55:Es4/iv, Mus.2-N-13,11 (Zohn 3), http://digital.slub-dresden.de/id320691489, Image 6 ("Violino Primo": Morgenstern [D2]). 


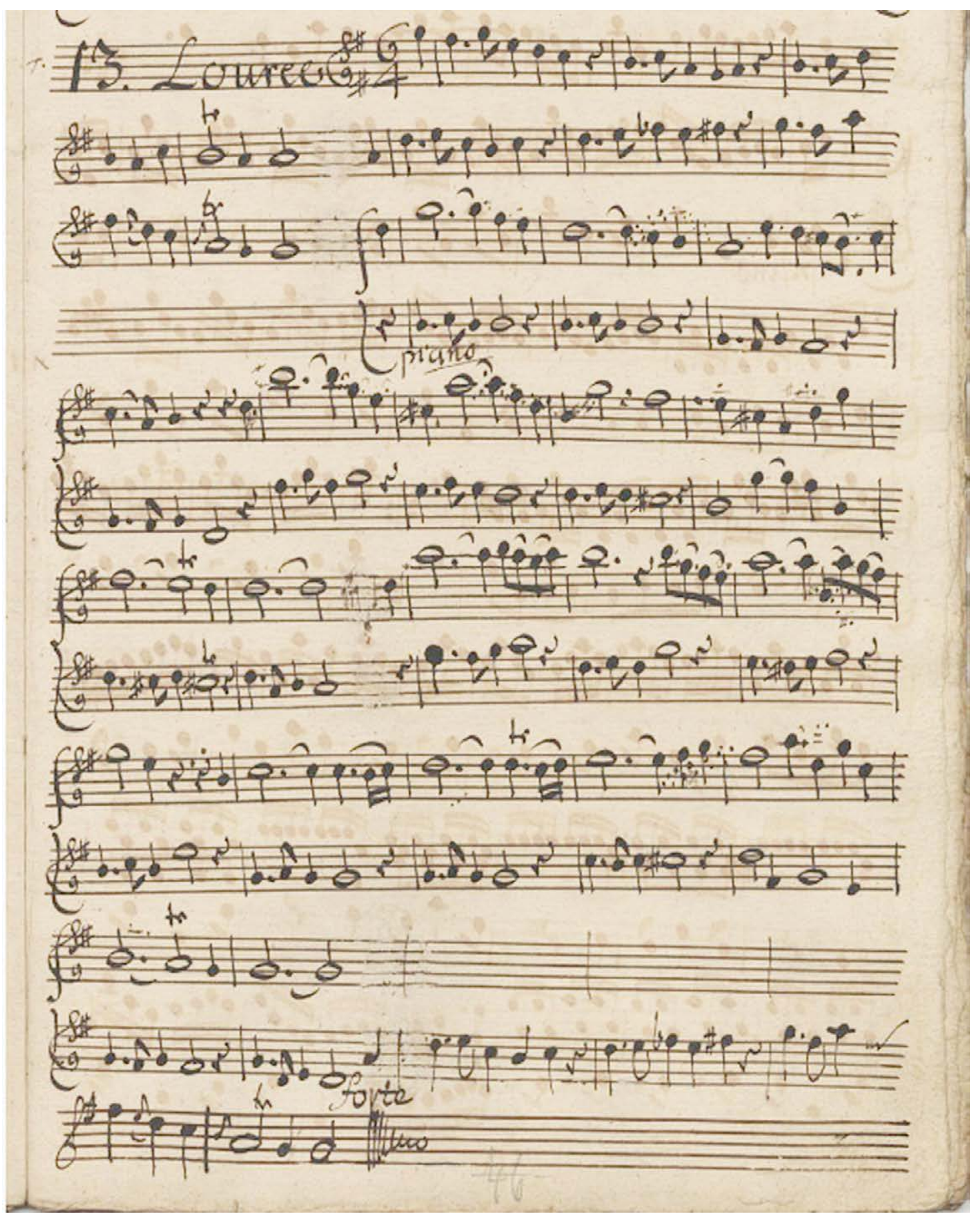

Illustration 13: Pisendel, ornamentation to Telemann, TWV 55:G6/iv, Mus.2-N-13,10,

http://digital.slub-dresden.de/id322161835, Image 15 (“Violino Primo Conc.”: Grundig [A1]). 


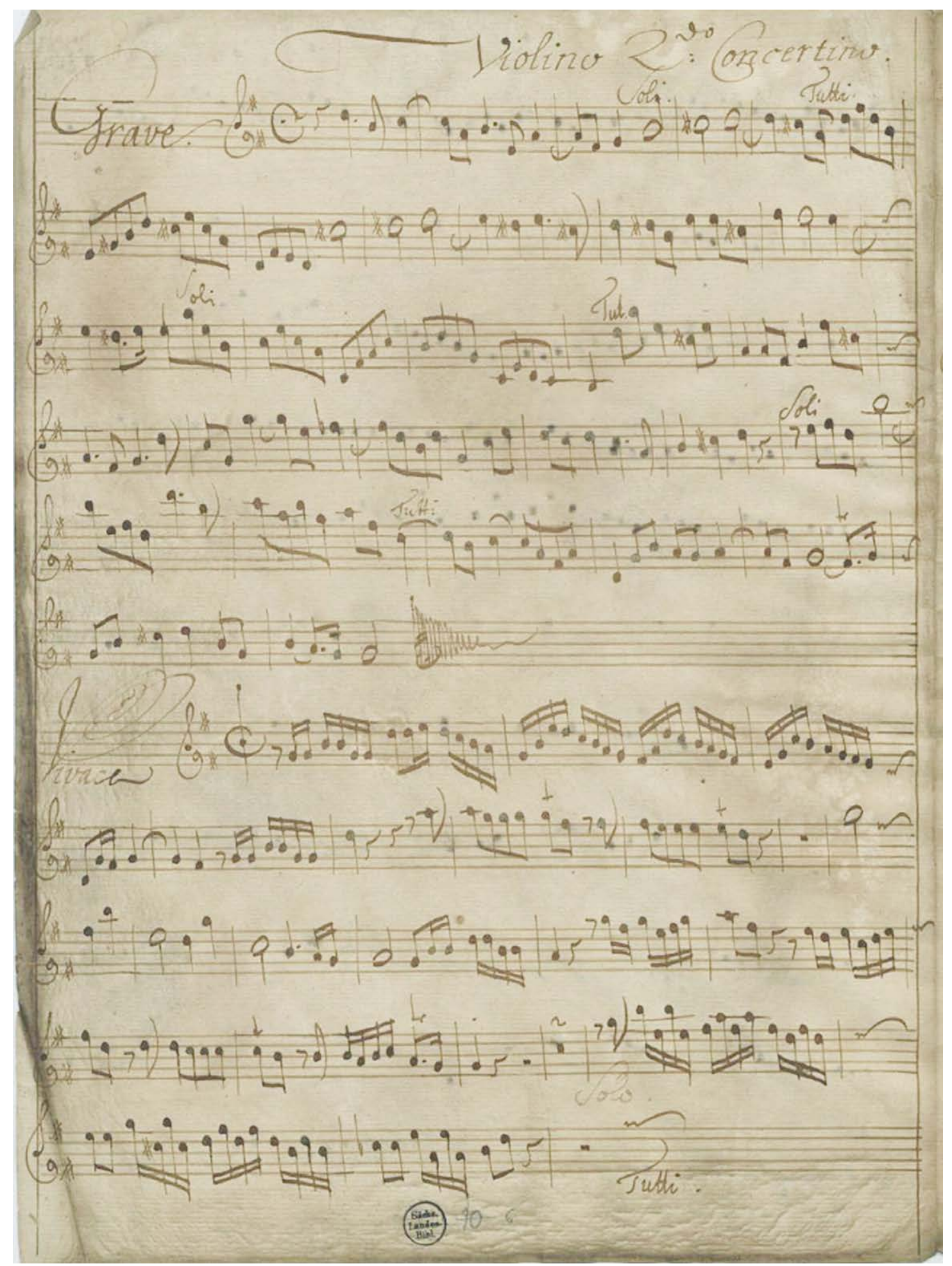

Illustration 14: Telemann, TWV 52:G1, Mus.2392-O-36, http://digital.slub-dresden.de/id316311715, Image 11 ("Violino ${ }^{\text {do }}$ Concertino": Schreiber P1). 


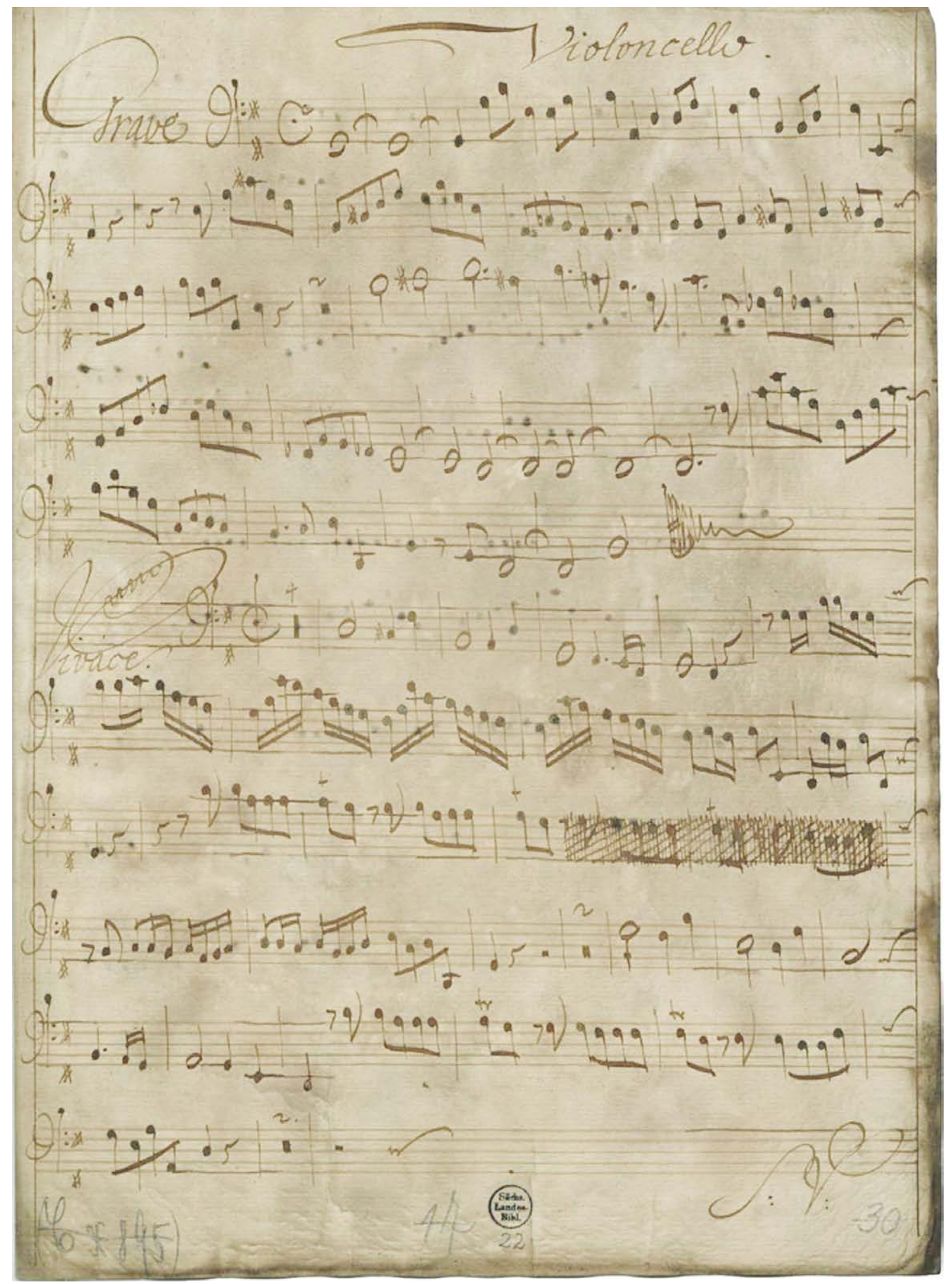

Illustration 15: Telemann, TWV 52:G1, Mus.2392-O-36, http://digital.slub-dresden.de/id316311715, Image 27 ("Violoncello": Schreiber P1). 


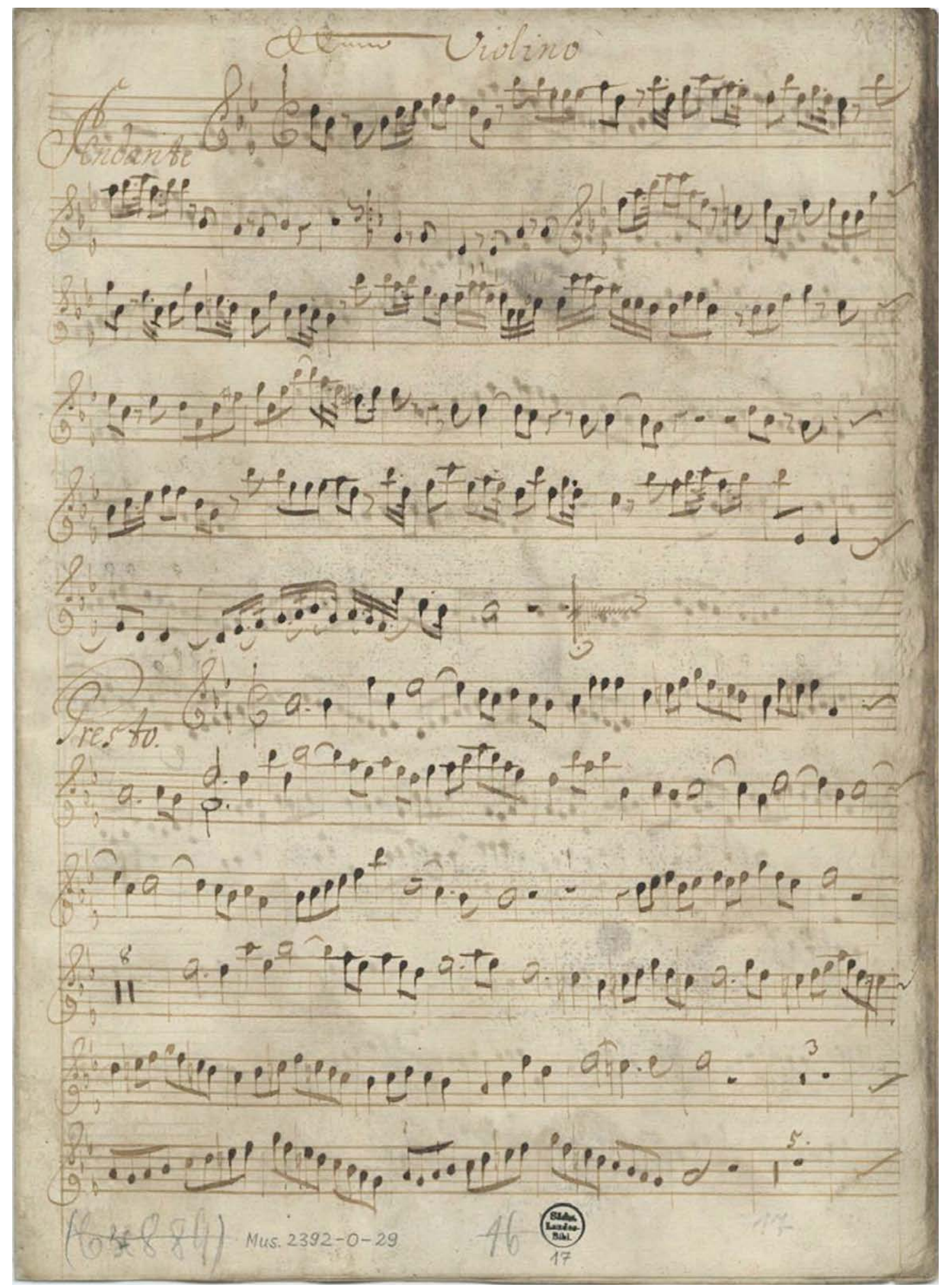

Illustration 16: Telemann, TWV 54:B2, Mus.2392-O-29, http://digital.slub-dresden.de/id304927392, Image 17 ("Violino": Schreiber P2). 


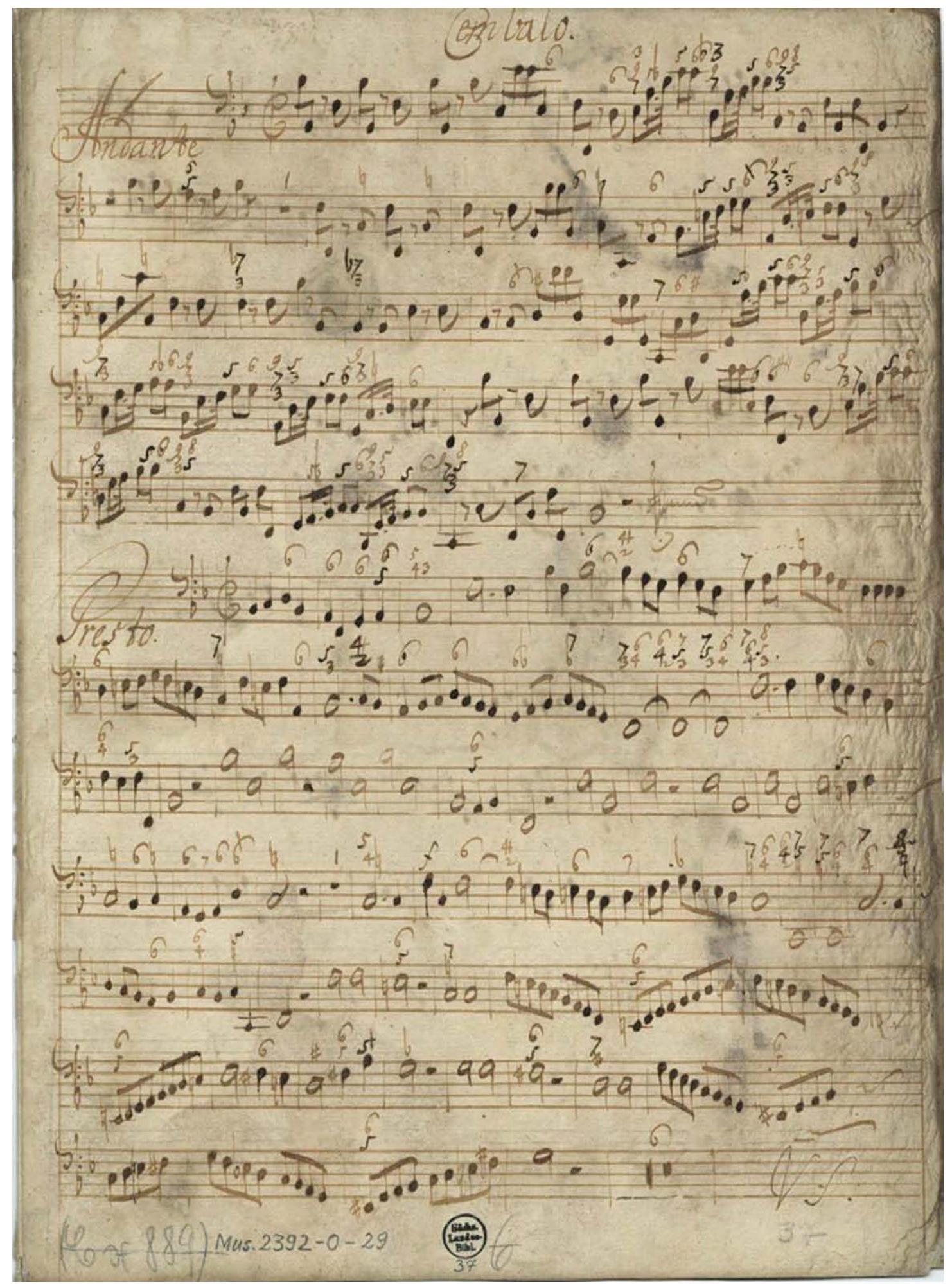

Illustration 17: Telemann, TWV 54:B2, Mus.2392-O-29, http://digital.slub-dresden.de/id304927392, Image 37 (“Cembalo”: Schreiber P2). 


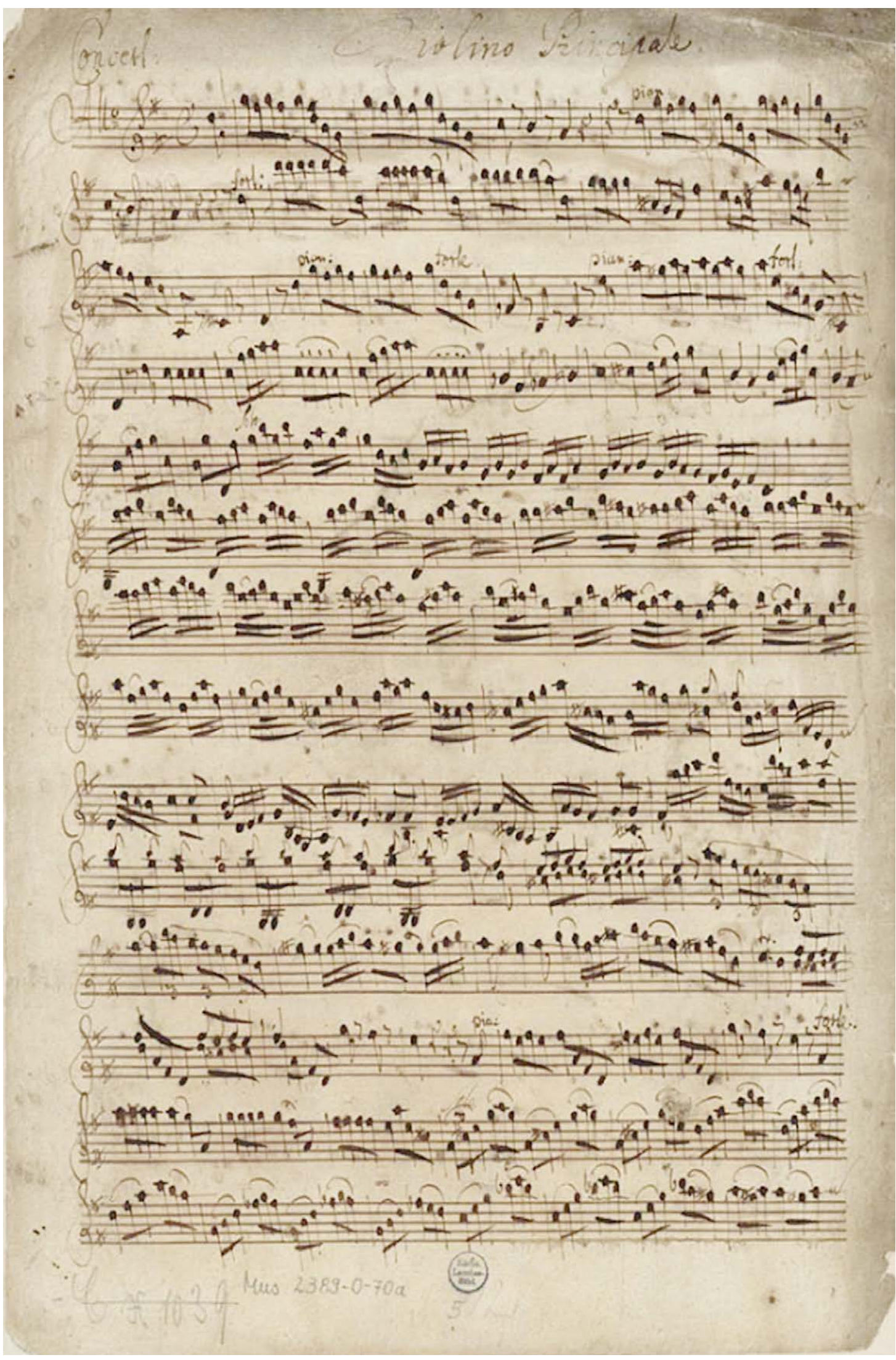

Illustration 18: Vivaldi, RV 314, Mus.2389-O-70a, http://digital.slub-dresden.de/id374944954, Image 1 ("Violino Principale": unknown copyist). 
Ofle:

emoalo

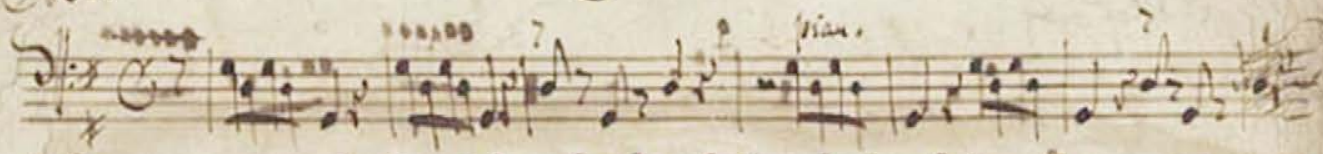

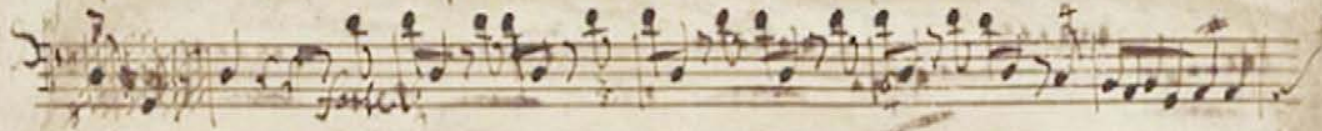

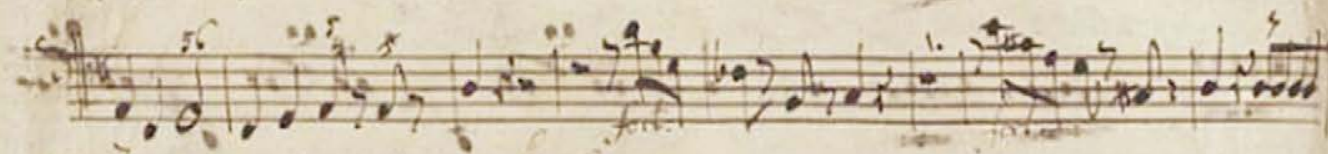

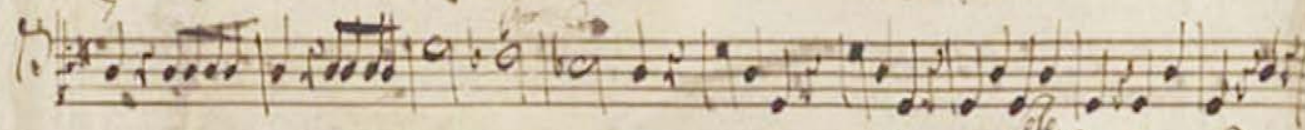

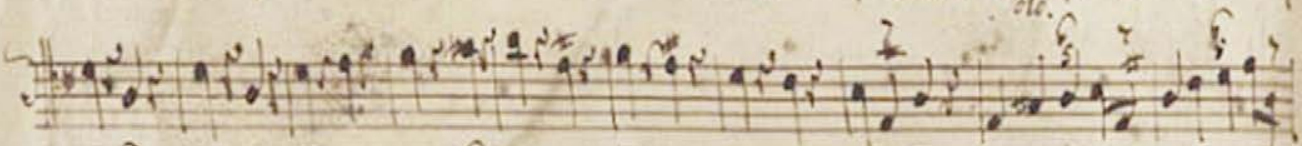

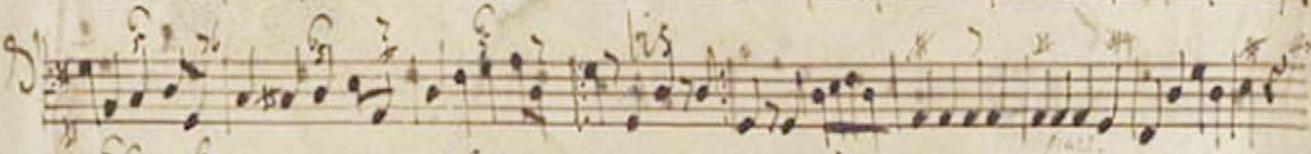

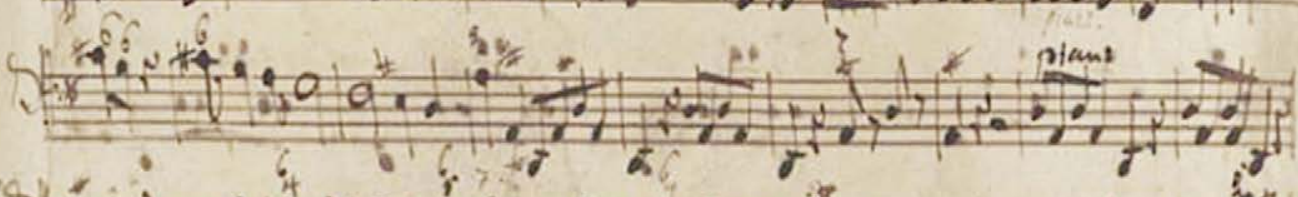

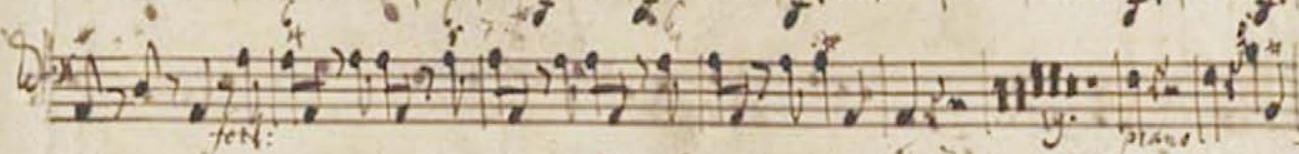

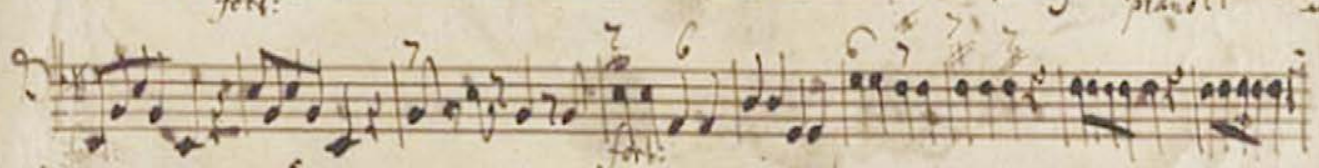

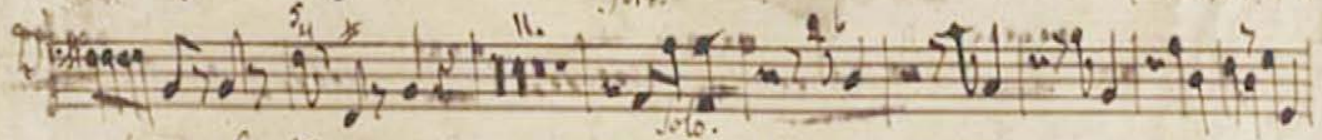

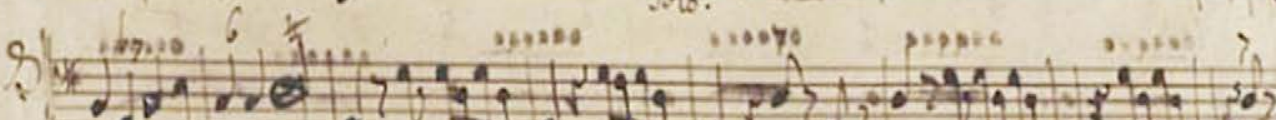

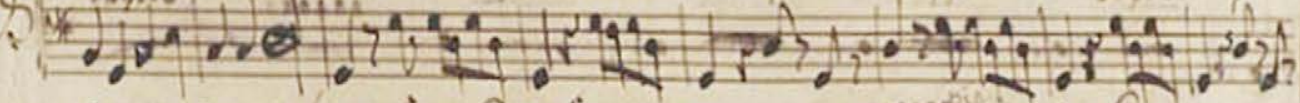

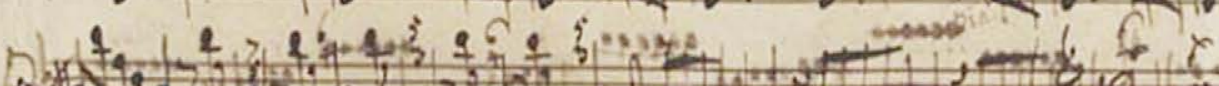

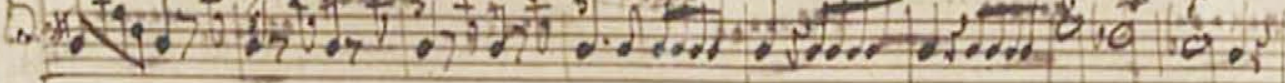

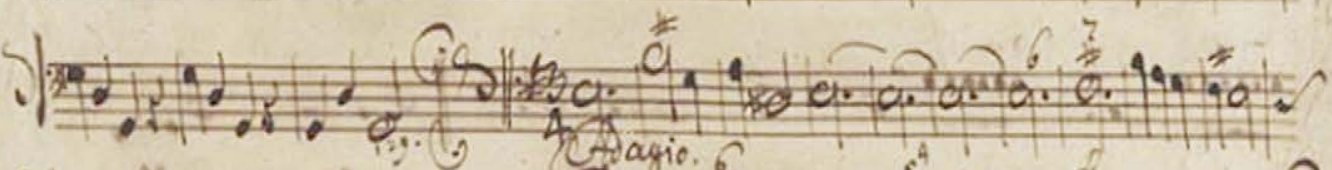

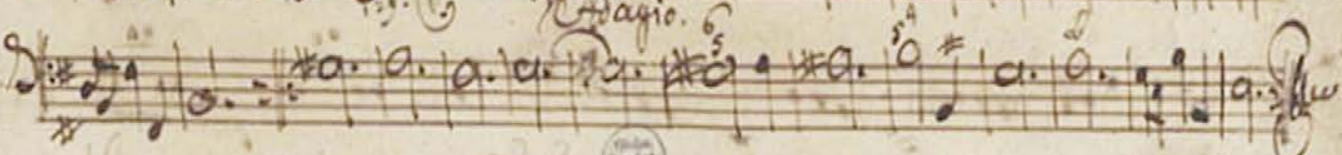
(i) I. $.1 \cdot v \cdot$ 4

Illustration 19: Vivaldi, RV 314, Mus.2389-O-70a, http://digital.slub-dresden.de/id374944954, Image 15 (“Cembalo": unknown copyist). 


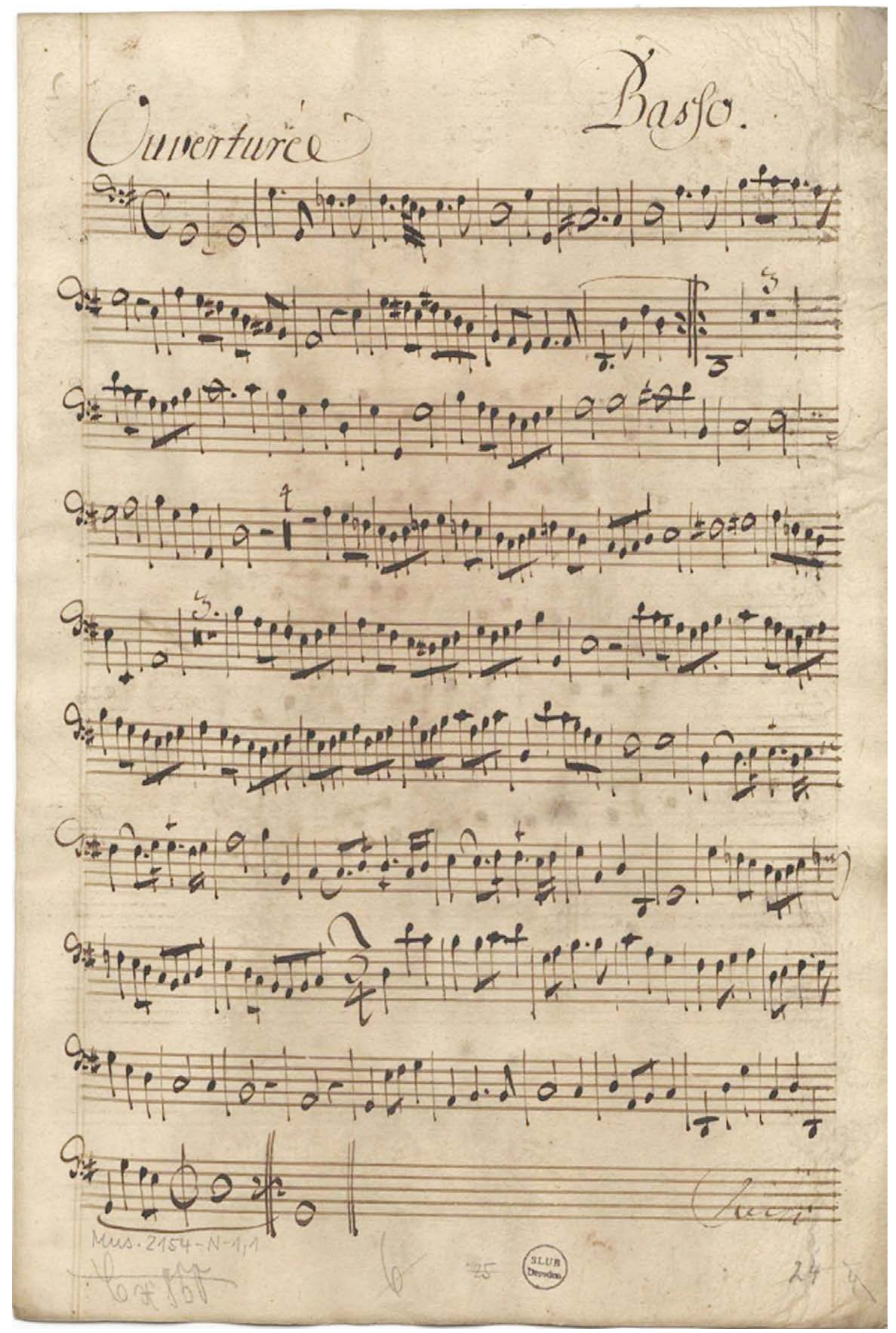

Illustration 20: J. C. Schmidt, Ouverture in G, Mus.2154-N-1,1,

http://digital.slub-dresden.de/id307193993, Image 37 (“Basso": Lindner). 


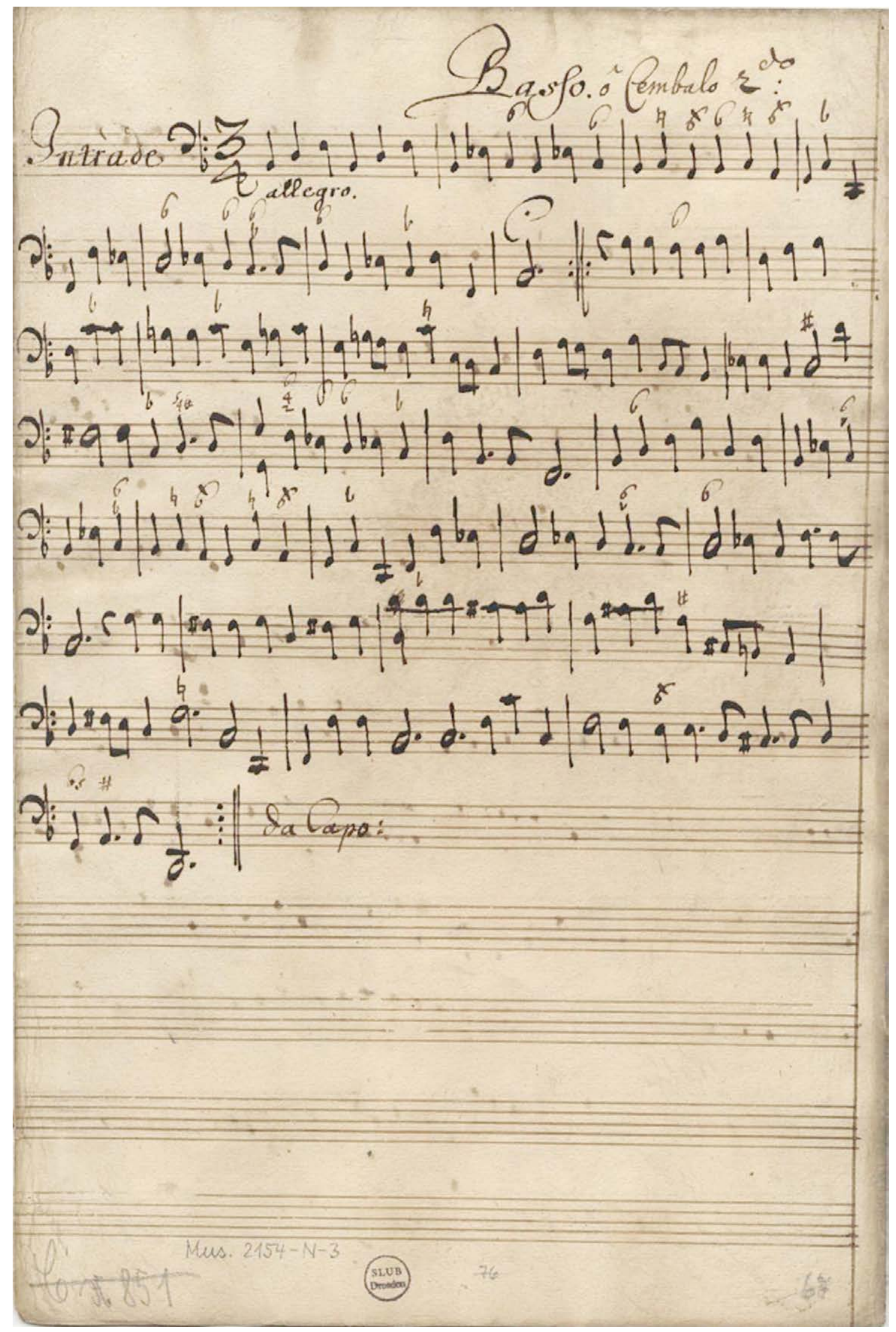

Illustration 21: J. C. Schmidt, Partie à deux Choeurs, Mus.2154-N-3, http://digital.slub-dresden.de/ id311506720, Image 85 (“Basso o Cembalo $2^{\mathrm{do} ": ~ J . ~ W . ~ S c h m i d t) . ~}$ 
Simphonia

Diohino IOncentato. (0)

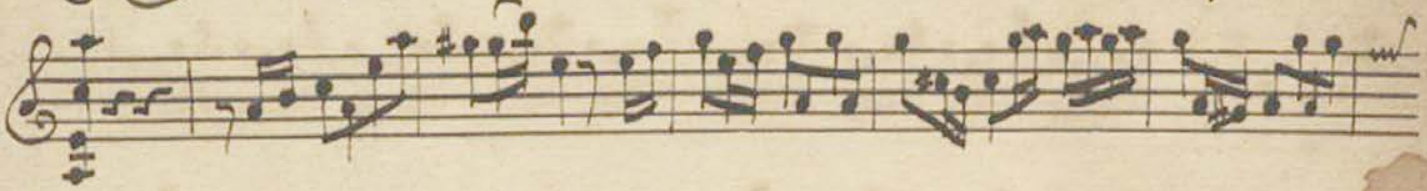
20.5ं

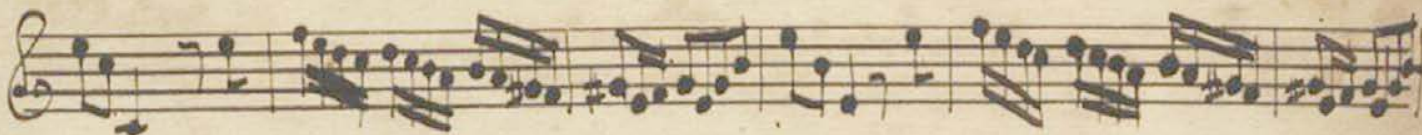

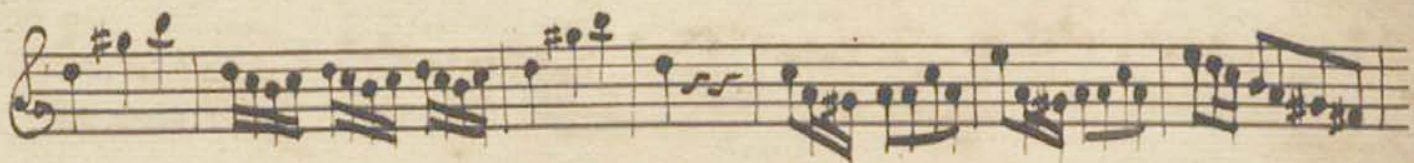

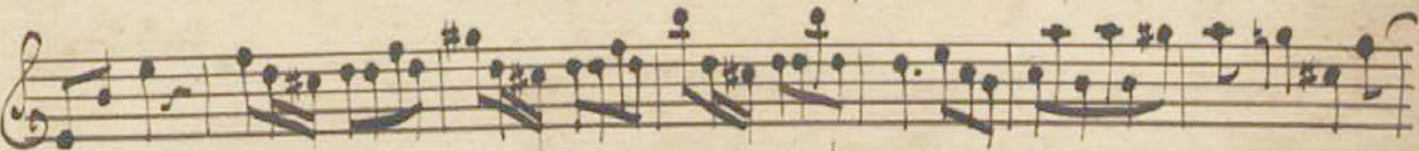

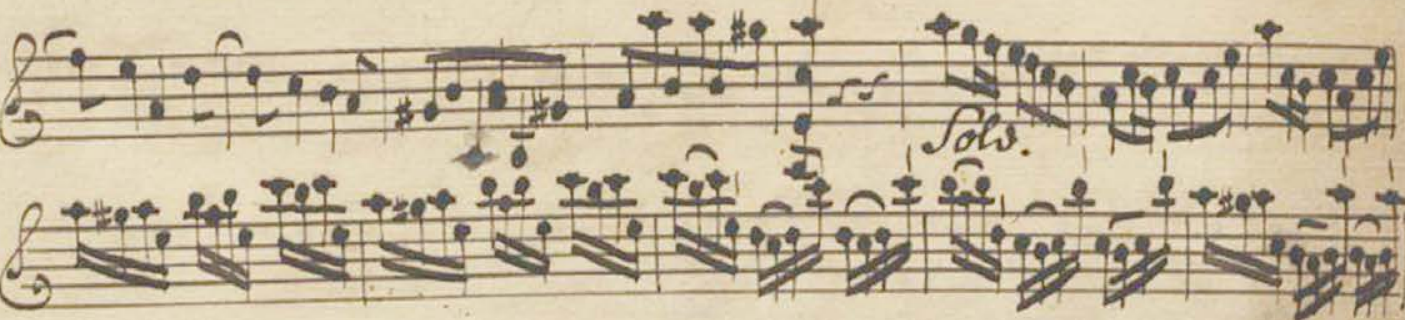
2

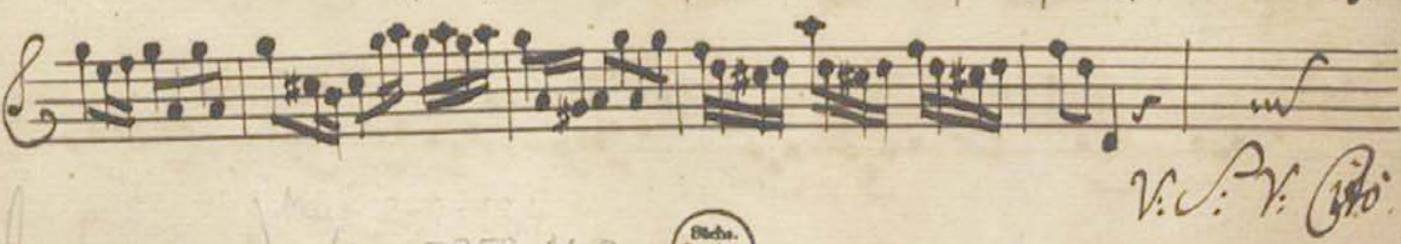

Illustration 22: Zelenka, Sinfonia, ZWV 189, Mus.2358-N-9a, http://digital.slub-dresden.de/ id311658547, Image 5 ("Violino I I Concertato": Morgenstern?). 


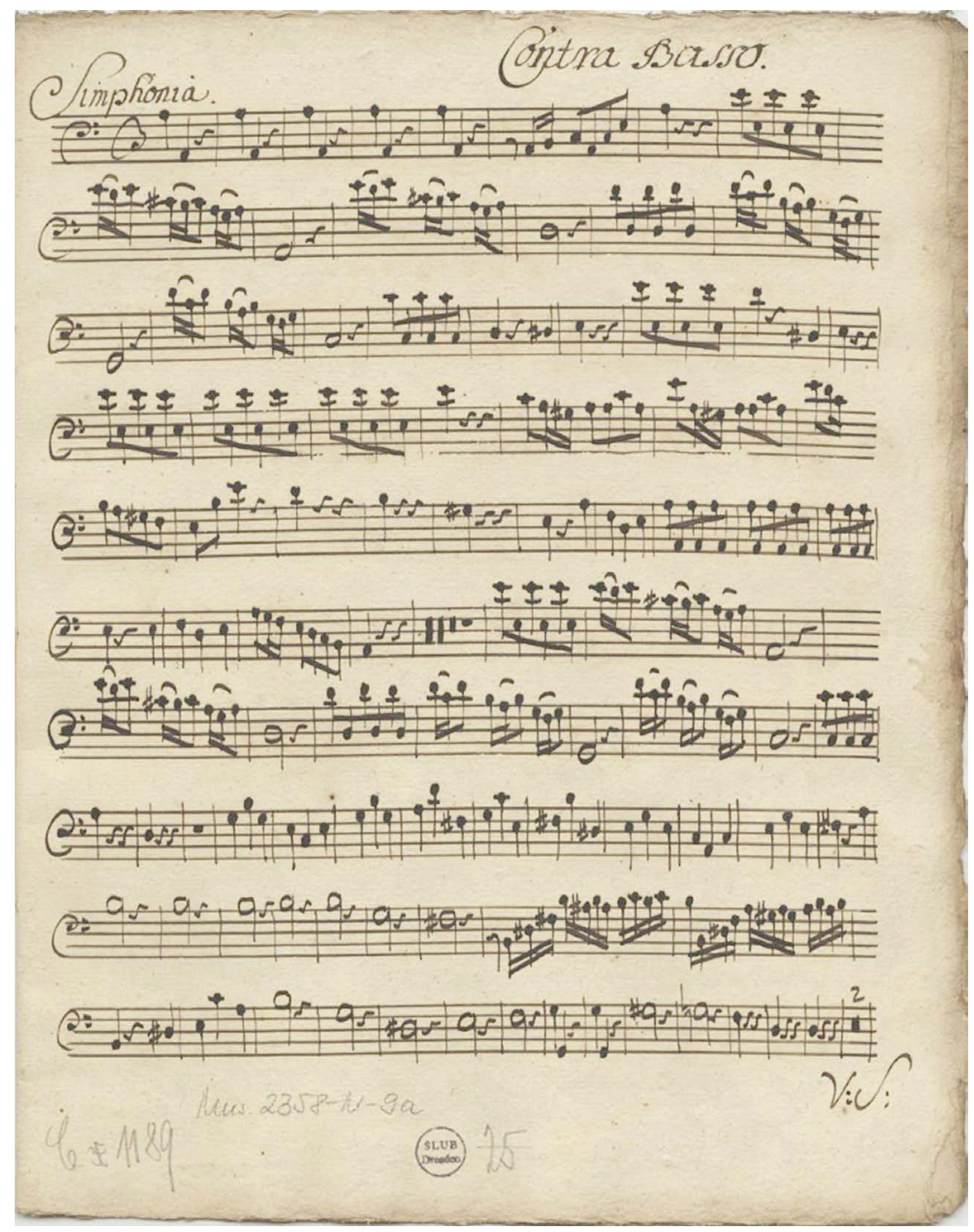

Illustration 23: Zelenka, Sinfonia, ZWV 189, Mus.2358-N-9a, http://digital.slub-dresden.de/ id311658547, Image 73 (“Contra Basso": Morgenstern?). 

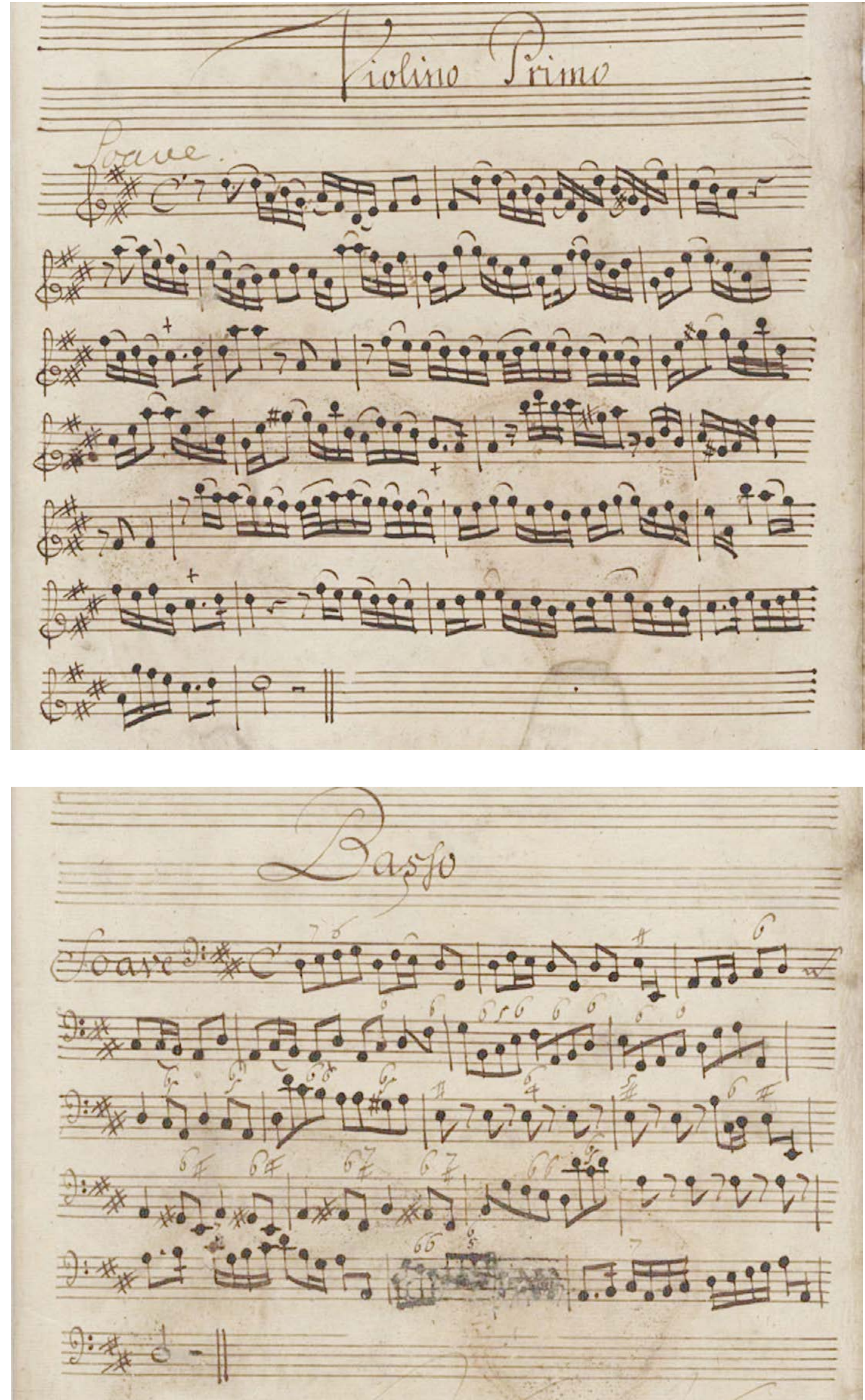

Illustrations 24a-b: Telemann, TWV 42:D1, Mus.2392-Q-6, http://digital.slub-dresden.de/ id316352381, Images 2 and 10 ("Violino Primo," "Basso": Morgenstern (D1)). 


$$
\text { Upertura Jiolino imo }
$$

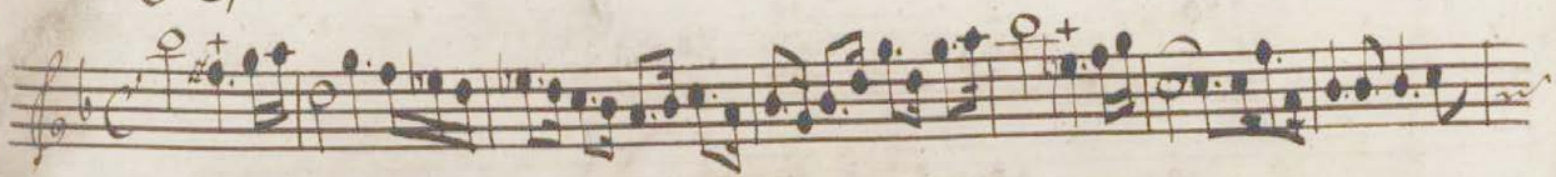

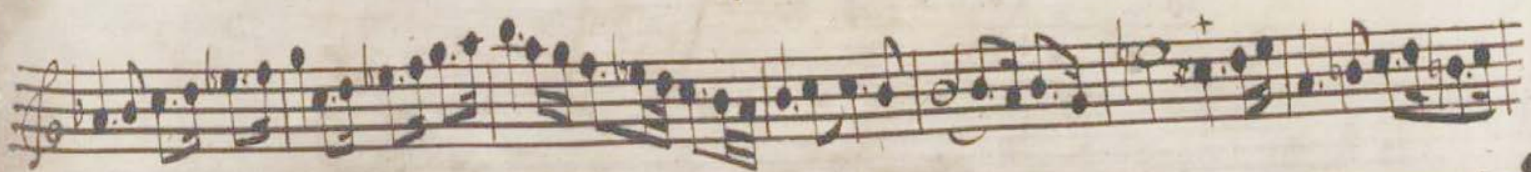
(7)

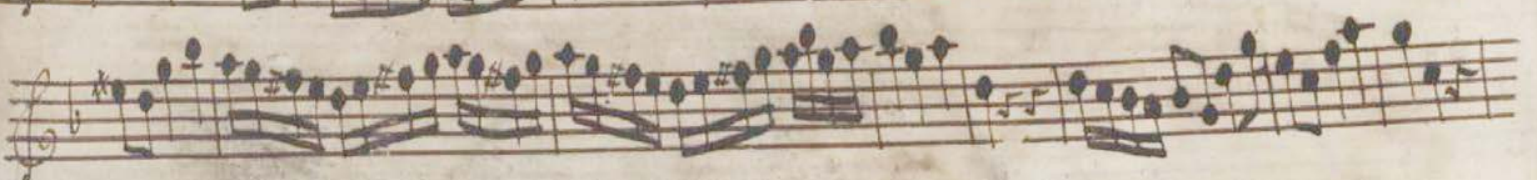

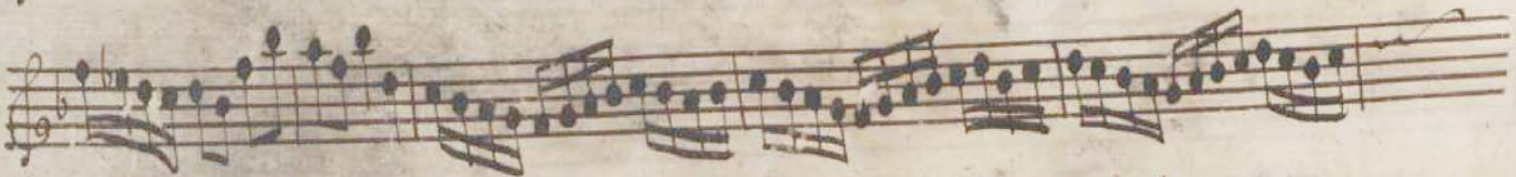

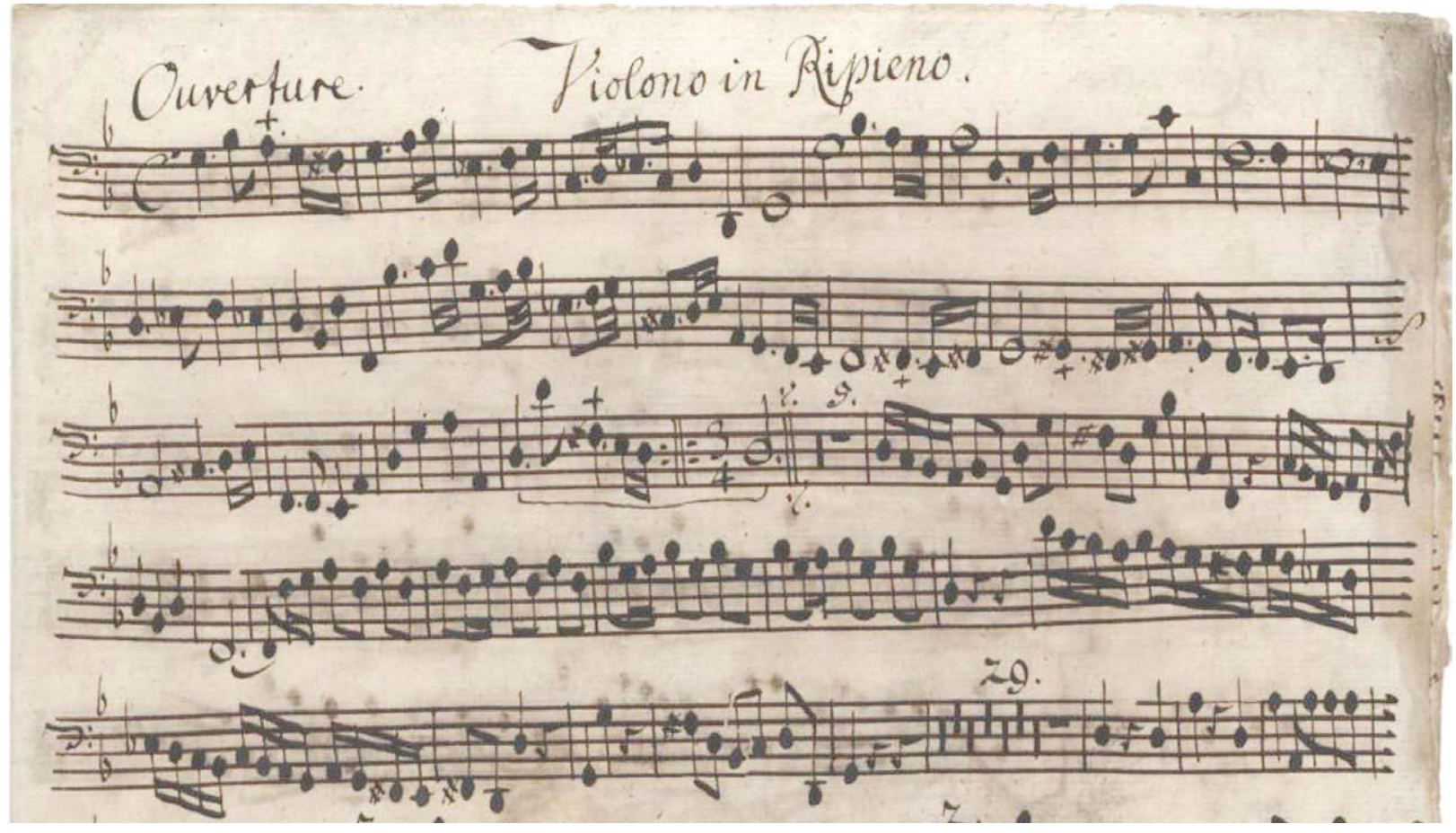

Illustrations 25a-b: Telemann, TWV 55:g8, Mus.2392-O-41, http://digital.slub-dresden.de/ id316334731, Images 2 and 25 ("Violino 1 ${ }^{\mathrm{mo}}$," "Violono in Ripieno": Morgenstern (D0)). 

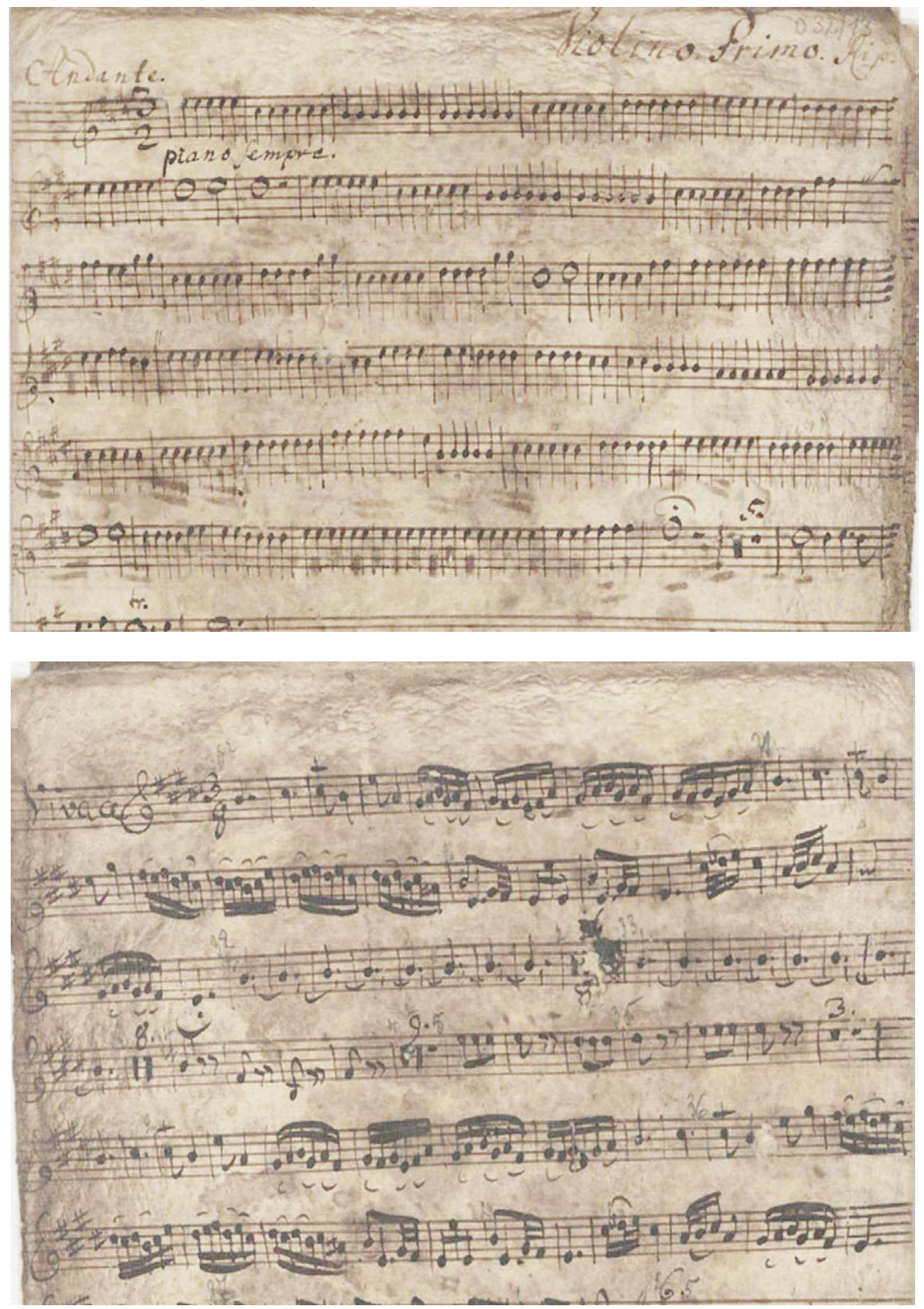

Illustrations 26a-b: Telemann, TWV 53:E1/i and iv, Mus.2392-O-32, http://digital.slub-dresden.de/ id304949612, Images 13 and 16 (“Violino.Primo.Rip:": S-Dl-026 and 033). 


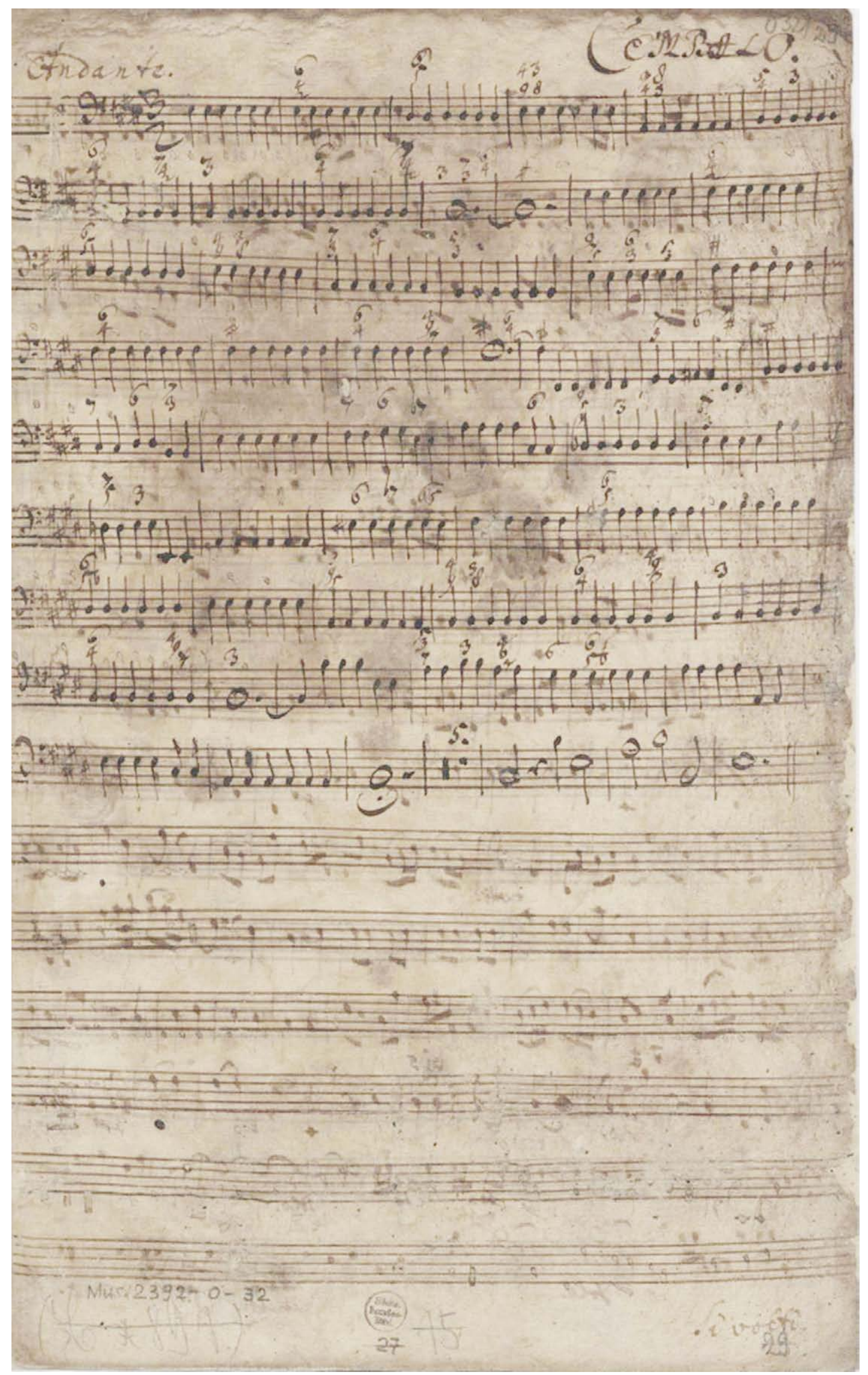

Illustration 27a: Telemann, TWV 53:E1/i and iv, Mus.2392-O-32, http://digital.slub-dresden.de/ id304949612, Image 29 (“Cembalo": S-Dl-026 and 033). 


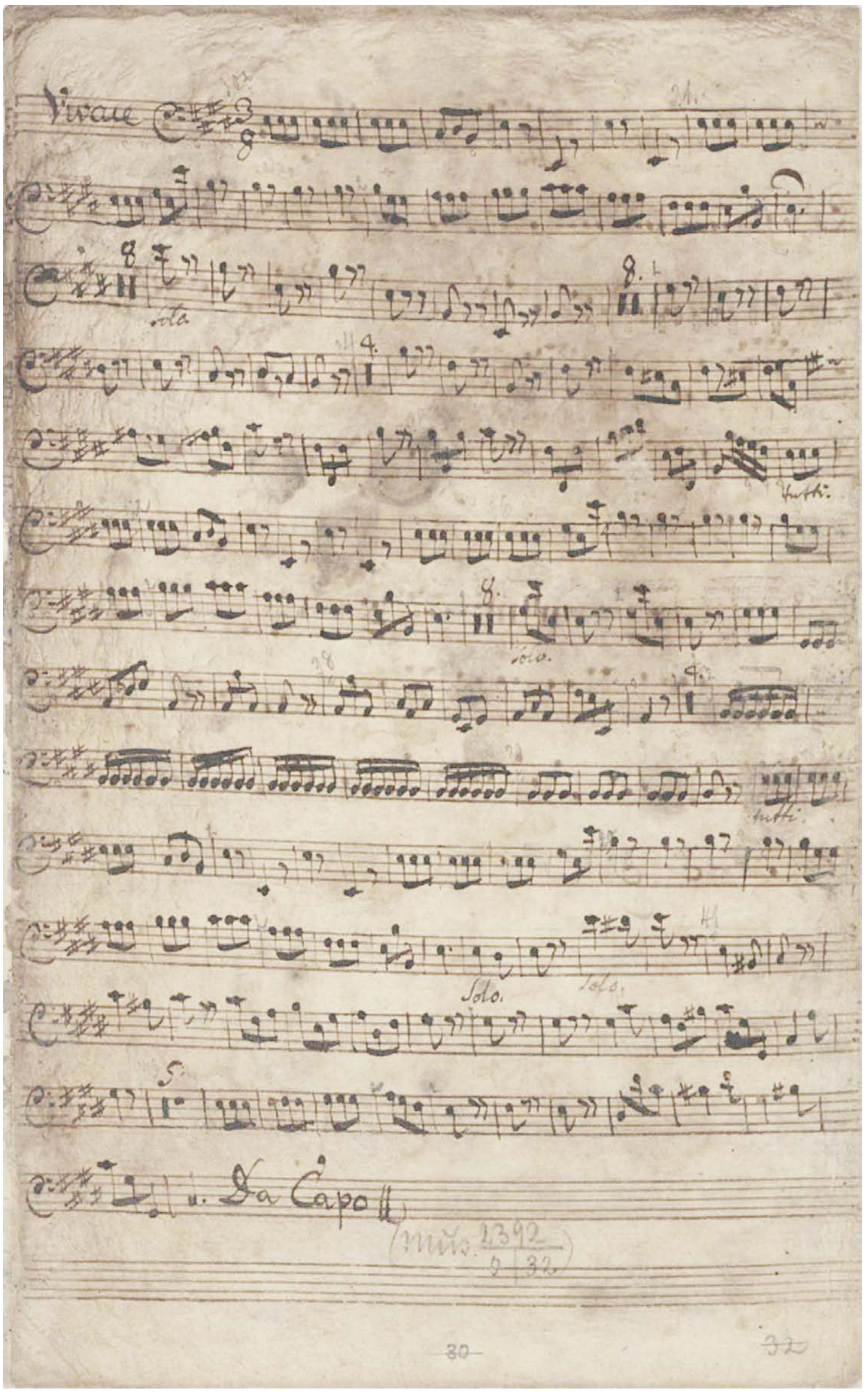

Illustration 27b: Telemann, TWV 53:E1/i and iv, Mus.2392-O-32, http://digital.slub-dresden.de/ id304949612, Image 32 (“Cembalo": S-Dl-026 and 033). 